\title{
The Dos Republicas Project: Phase II Archaeological Investigations at a Proposed Coal Strip Mine, Maverick County, Texas
}

Herbert G. Uecker

Center for Archaeological Research

Follow this and additional works at: https://scholarworks.sfasu.edu/ita

Part of the American Material Culture Commons, Archaeological Anthropology Commons, Environmental Studies Commons, Other American Studies Commons, Other Arts and Humanities Commons, Other History of Art, Architecture, and Archaeology Commons, and the United States History Commons

Tell us how this article helped you.

This Article is brought to you for free and open access by the Center for Regional Heritage Research at SFA ScholarWorks. It has been accepted for inclusion in Index of Texas Archaeology: Open Access Gray Literature from the Lone Star State by an authorized editor of SFA ScholarWorks. For more information, please contact cdsscholarworks@sfasu.edu. 


\section{The Dos Republicas Project: Phase II Archaeological Investigations at a Proposed Coal Strip Mine, Maverick County, Texas}

\section{Creative Commons License}

\section{(c) (1) \&}

This work is licensed under a Creative Commons Attribution-NonCommercial 4.0 International License 


\section{THE DOS REPUBLICAS PROJECT: PHASE II ARCHAEOLOGICAL INVESTIGATIONS AT A PROPOSED COAL STRIP MINE, MAVERICK COUNTY, TEXAS}

Herbert G. Uecker

Center for Archaeological Research The University of Texas at San Antonio Archaeological Survey Report, $\mathrm{No} .215$ 



\section{THE DOS REPUBLICAS PROJECT: PHASE II ARCHAEOLOGICAL INVESTIGATIONS AT A PROPOSED COAL STRIP MINE, MAVERICK COUNTY, TEXAS}

Herbert G. Uecker

Center for Archaeological Research The University of Texas at San Antonio Archaeological Survey Report, No. 215 
The following information is provided in accordance with the General Rules of Practice and Procedure, Chapter 41.11 (Investigative Reports), Texas Antiquities Committee:

1. Type of investigation: Survey and testing (Phase II)

2. Project name: The Dos Republicas Project

3. County: Maverick

4. Principal Investigator: Jack Eaton and Robert J. Hard

5. Name and location of sponsoring agency: Railroad Commission of Texas

6. Texas Antiquities Committee Permit No.: None

7. Published by the Center for Archaeological Research of The University of Texas at San Antonio, San Antonio, Texas 78249-0658, 1994.

A list of publications by the Center for Archaeological Research can be obtained by sending $\$ 1.00$ to the Center for Archaeological Research, The University of Texas at San Antonio, San Antonio, Texas 78249-0658. 


\begin{abstract}
During February and March 1992, the Center for Archaeological Research of The University of Texas at San Antonio conducted an intensive investigation of a proposed coal strip mine near Eagle Pass, Maverick County, Texas. Twenty-seven previously unrecorded archaeological sites were discovered and several that were recorded in 1981 were reexamined. Postulated cultural affiliations include the Late Paleo-Indian, Middle-to-Late Archaic, Late Prehistoric, and Historic periods. Eight sites were found to be particularly significant because of their potential for listing in the National Register of Historic Places or designation as state archeological landmarks. After review of the results of the investigation by the project sponsors; the Texas Historical Commission, Department of Antiquities Protection; and the Railroad Commission of Texas, 29 additional sites within the coal mine permit area were deemed worthy of future work. A general research outline for future work and comprehensive environmental, historical, and cultural contexts for the area investigated are also presented.
\end{abstract}




\section{TABLE OF CONTENTS}

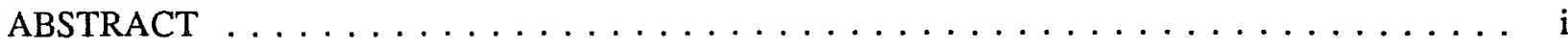

LIST OF FIGURES $\ldots \ldots \ldots \ldots \ldots \ldots \ldots \ldots \ldots \ldots \ldots \ldots \ldots \ldots \ldots \ldots \ldots$ iii

LIST OF TABLES $\ldots \ldots \ldots \ldots \ldots \ldots \ldots \ldots \ldots \ldots \ldots \ldots \ldots \ldots \ldots \ldots \ldots$ iii

ACKNOWLEDGMENTS $\ldots \ldots \ldots \ldots \ldots \ldots \ldots \ldots \ldots \ldots \ldots \ldots \ldots \ldots \ldots \ldots \ldots$ iv

INTRODUCTION $\ldots \ldots \ldots \ldots \ldots \ldots \ldots \ldots \ldots \ldots \ldots \ldots \ldots \ldots \ldots \ldots \ldots \ldots \ldots$

SCOPE OF WORK AND METHODOLOGY $\ldots \ldots \ldots \ldots \ldots \ldots \ldots \ldots \ldots \ldots$

LOCATION, HISTORY, AND GENERAL CHARACTERISTICS OF THE PERMIT AREA . . 9

NATURAL SETTING AND NATURAL HISTORY $\ldots \ldots \ldots \ldots \ldots \ldots \ldots \ldots \ldots .11$

PREVIOUS CULTURAL INVESTIGATIONS AND ANALYSES $\ldots \ldots \ldots \ldots \ldots \ldots \ldots$

ARCHAEOLOGICAL SITES AND ARTIFACTS $\ldots \ldots \ldots \ldots \ldots \ldots \ldots \ldots \ldots \ldots . \ldots \ldots$

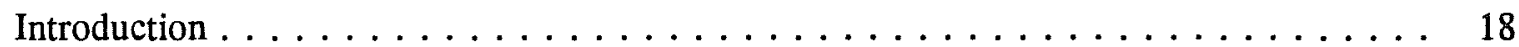

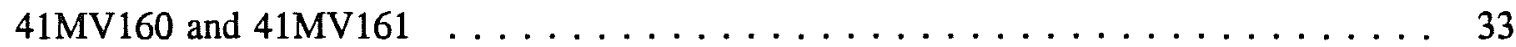

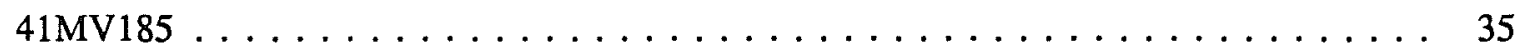

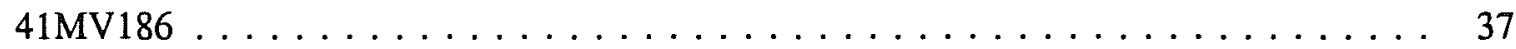

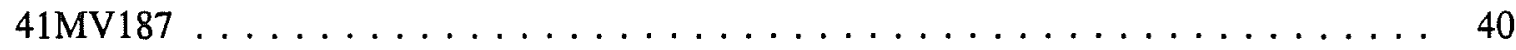

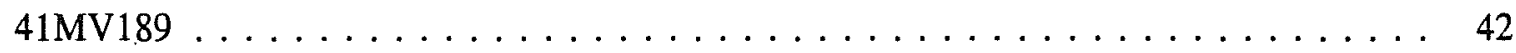

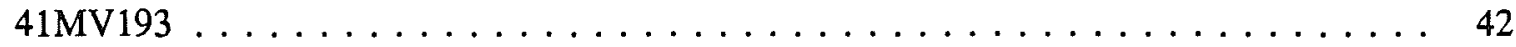

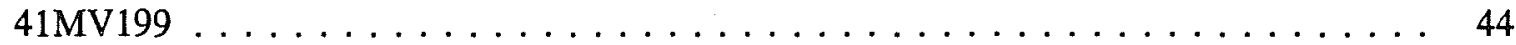

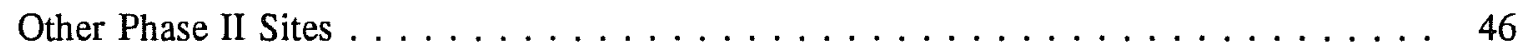

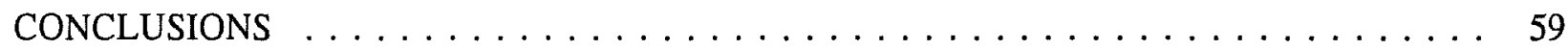

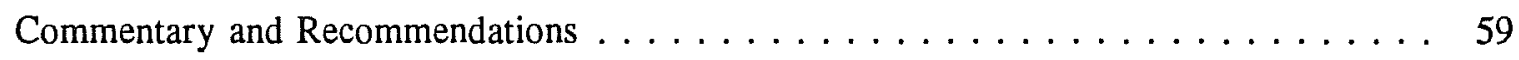

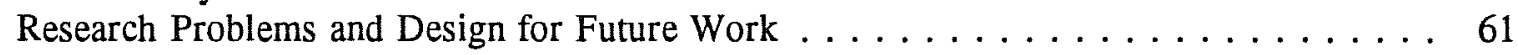

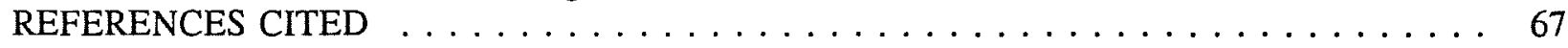

APPENDIX I: GEOLOGICAL STUDY OF THE DOS REPUBLICAS STRIP MINE . . . . . . 79

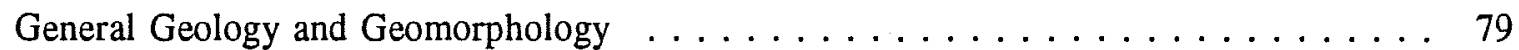

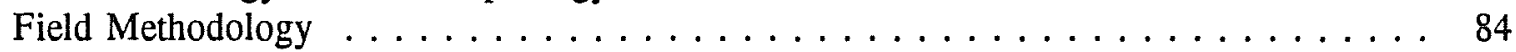

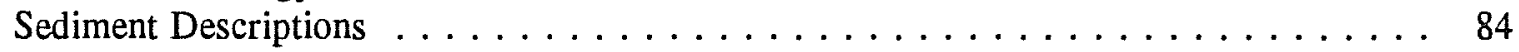

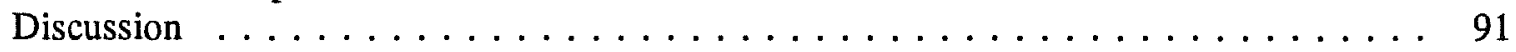

Summary and Archaeological Implications . . . . . . . . . . . . . 95

References Cited ......................... 98

APPENDIX II: BACKHOE TRENCH PROFILE ANALYSIS $\ldots \ldots \ldots \ldots \ldots \ldots \ldots \ldots .100$

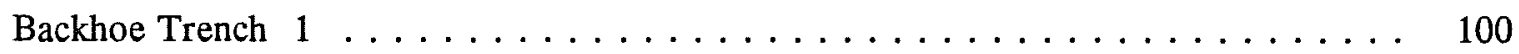

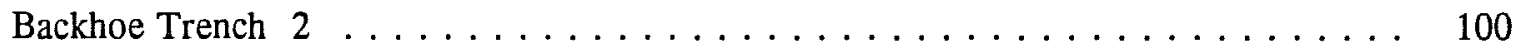

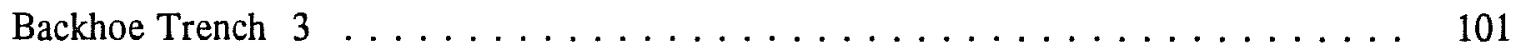

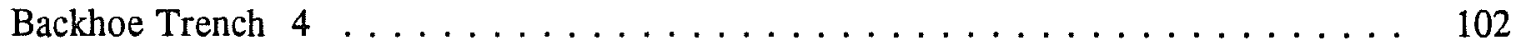

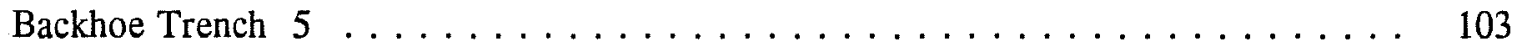

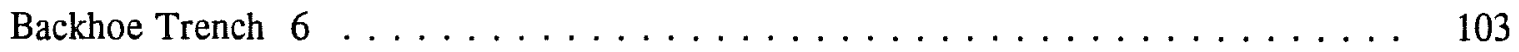

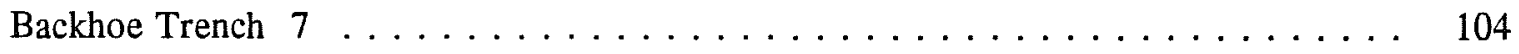

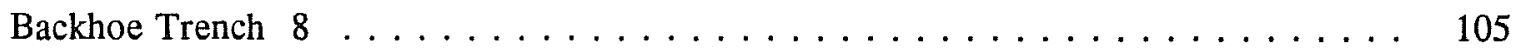

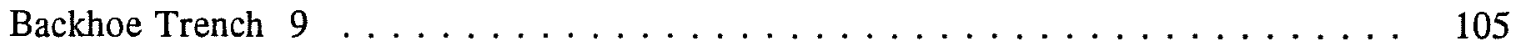

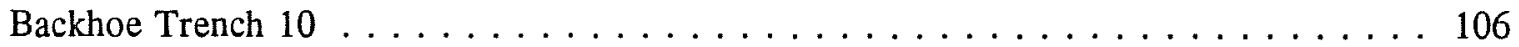

Backhoe Trench $11 \ldots \ldots \ldots \ldots \ldots$. . . . . . . . . . . . . . . . 107

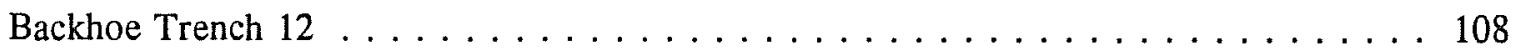

Backhoe Trench $13 \ldots \ldots \ldots \ldots$. . . . . . . . . . . . . . . . . . . 109

Backhoe Trench $14 \ldots \ldots \ldots \ldots$. . . . . . . . . . . . . . . . . . . . 109

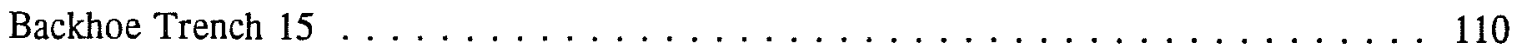

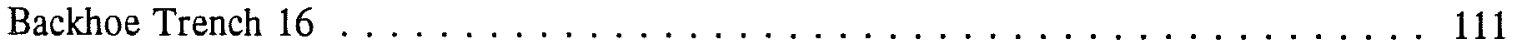




\begin{abstract}
During February and March 1992, the Center for Archaeological Research of The University of Texas at San Antonio conducted an intensive investigation of a proposed coal strip mine near Eagle Pass, Maverick County, Texas. Twenty-seven previously unrecorded archaeological sites were discovered and several that were recorded in 1981 were reexamined. Postulated cultural affiliations include the Late Paleo-Indian, Middle-to-Late Archaic, Late Prehistoric, and Historic periods. Eight sites were found to be particularly significant because of their potential for listing in the National Register of Historic Places or designation as state archeological landmarks. After review of the results of the investigation by the project sponsors; the Texas Historical Commission, Department of Antiquities Protection; and the Railroad Commission of Texas, 29 additional sites within the coal mine permit area were deemed worthy of future work. A general research outline for future work and comprehensive environmental, historical, and cultural contexts for the area investigated are also presented.
\end{abstract}




\section{TABLE OF CONTENTS}

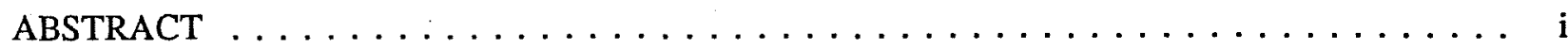

LIST OF FIGURES $\ldots \ldots \ldots \ldots \ldots \ldots \ldots \ldots \ldots \ldots \ldots \ldots \ldots \ldots \ldots \ldots \ldots$ ii

LIST OF TABLES $\ldots \ldots \ldots \ldots \ldots \ldots \ldots \ldots \ldots \ldots \ldots \ldots \ldots \ldots \ldots \ldots \ldots \ldots \ldots$

ACKNOWLEDGMENTS $\ldots \ldots \ldots \ldots \ldots \ldots \ldots \ldots \ldots \ldots \ldots \ldots \ldots \ldots$ iv

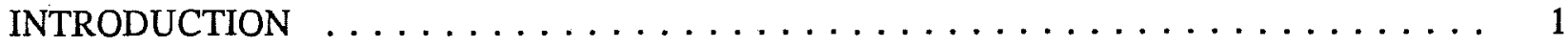

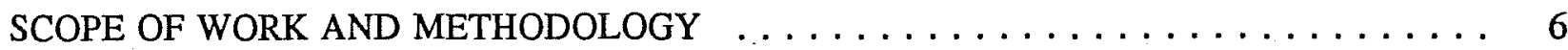

LOCATION, HISTORY, AND GENERAL CHARACTERISTICS OF THE PERMIT AREA . . 9

NATURAL SETTING AND NATURAL HISTORY $\ldots \ldots \ldots \ldots \ldots \ldots \ldots \ldots$

PREVIOUS CULTURAL INVESTIGATIONS AND ANALYSES . . . . . . . . . . . . . . 15

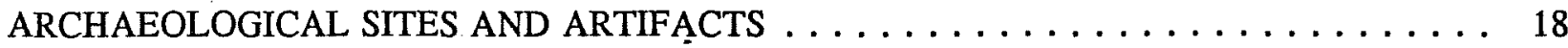

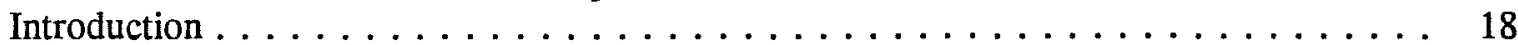

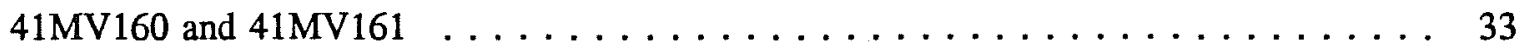

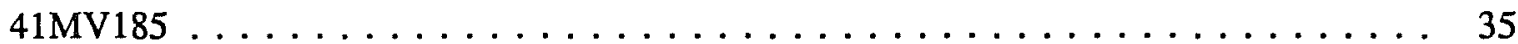

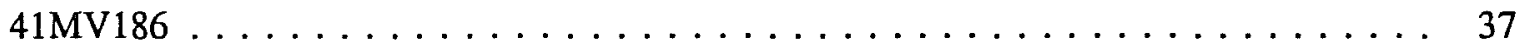

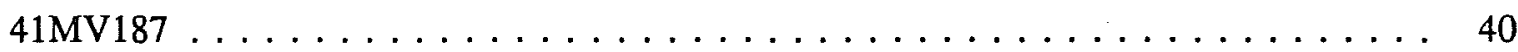

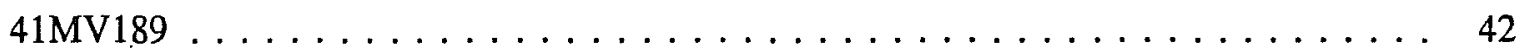

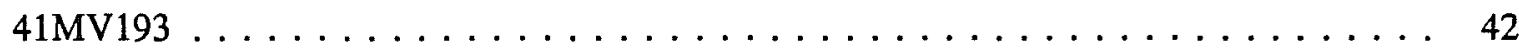

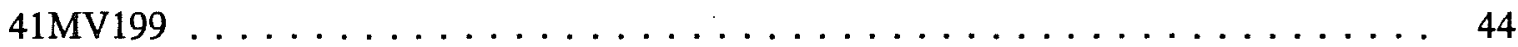

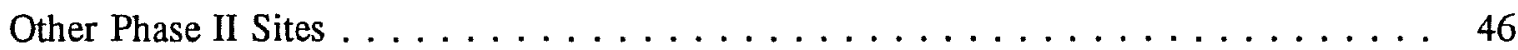

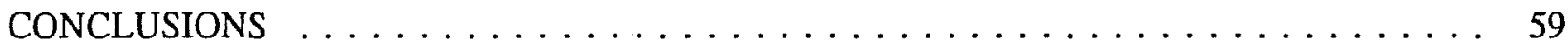

Commentary and Recommendations . . . . . . . . . . . . . . . . . 59

Research Problems and Design for Future Work . . . . . . . . . . . . . . 61

REFERENCES CITED . . . . . . . . . . . . . . . . . . . . . . . 67

APPENDIX I: GEOLOGICAL STUDY OF THE DOS REPUBLICAS STRIP MINE . . . . . . . 79

General Geology and Geomorphology . . . . . . . . . . . . . . 79

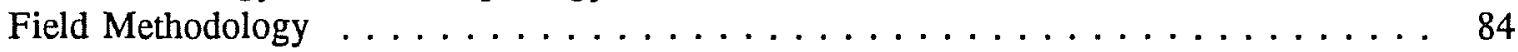

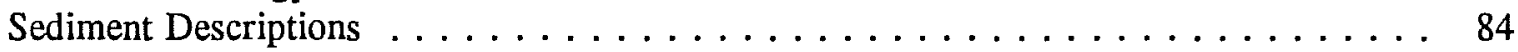

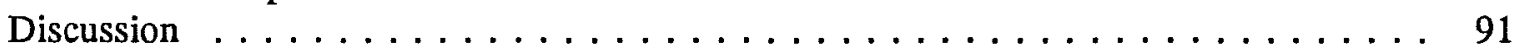

Summary and Archaeological Implications . . . . . . . . . . . . . . . 95

References Cited . . . . . . . . . . . . . . . . . . . . . . . . 98

APPENDIX II: BACKHOE TRENCH PROFILE ANALYSIS . . . . . . . . . . . 100

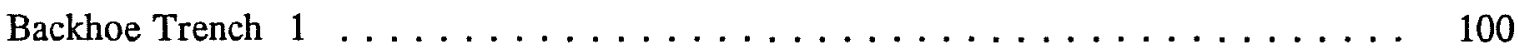

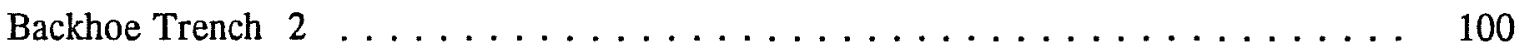

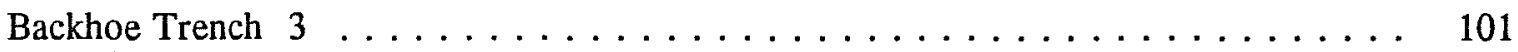

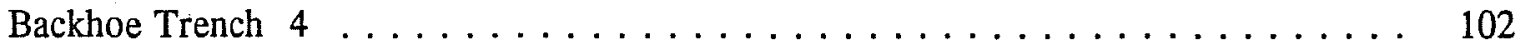

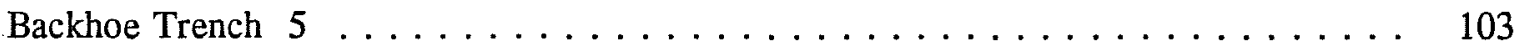

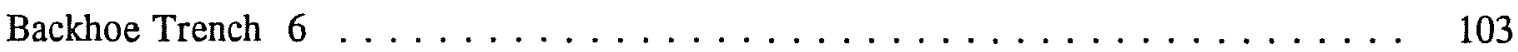

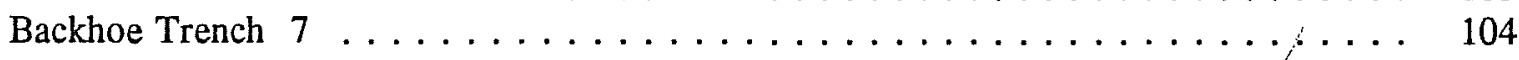

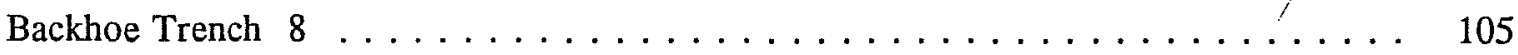

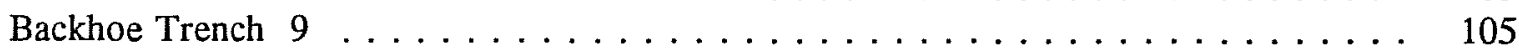

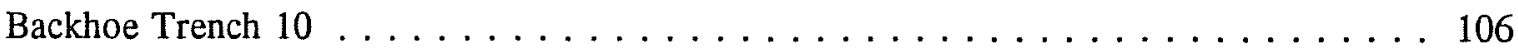

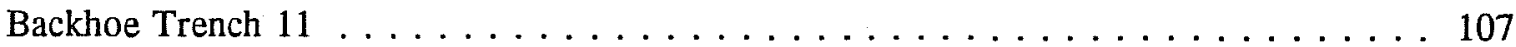

Backhoe Trench $12 \ldots \ldots \ldots \ldots \ldots \ldots \ldots \ldots \ldots$

Backhoe Trench $13 \ldots \ldots \ldots \ldots \ldots \ldots \ldots$

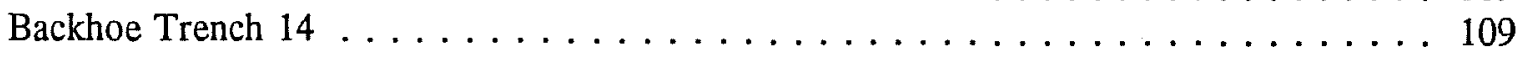

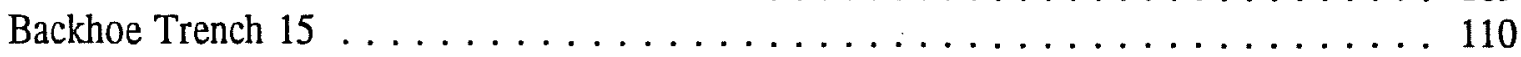

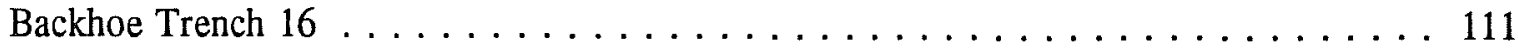




\section{LIST OF FIGURES}

1. Location of the Dos Republicas Proposed Coal Mine . . . . . . . . . . . . . 2

2. Locations of Archaeological Sites Recorded by CAR during Phase II Investigations . . . . . 3

3. Archaeological Sites Discovered by Espey, Huston \& Associates within the

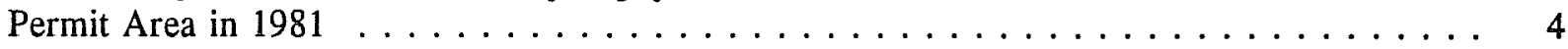

4. Diagnostic Surface Artifacts from the Phase II Dos Republicas Project Archaeological Survey 25

5. Diagnostic Surface Artifacts from the Phase II Dos Republicas Project Archaeological Survey 26

6. Surface Artifacts from the Phase II Dos Republicas Project Archaeological Survey . . . . . . 27

7. Surface Artifacts from the Phase II Dos Republicas Project Archaeological Survey . . . . . 28

8. Surface Artifacts from the Phase II Dos Republicas Project Archaeological Survey . . . . . . 29

9. Diagnostic Surface Artifacts from the Phase II Dos Republicas Project Archaeological Survey 30

10. Surface Artifacts from the Phase II Dos Republicas Project Archaeological Survey . . . . . . 31

11. Surface and Subsurface Artifacts from Site $41 \mathrm{MV} 199 \ldots \ldots \ldots \ldots \ldots \ldots \ldots \ldots$

12. Plan of Sites $41 \mathrm{MV} 159,41 \mathrm{MV} 160$, and $41 \mathrm{MV} 161 \ldots \ldots \ldots \ldots \ldots \ldots \ldots \ldots$

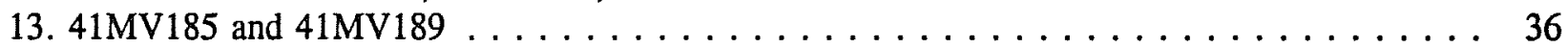

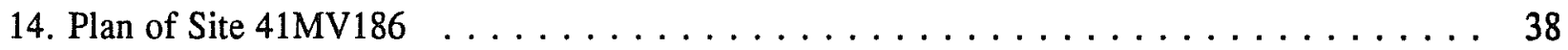

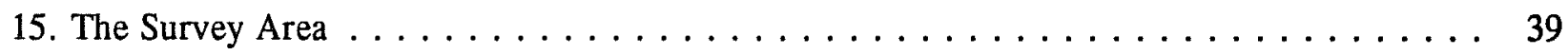

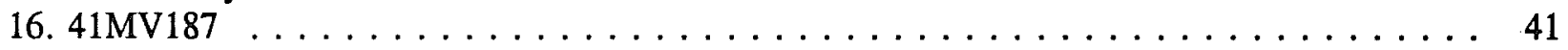

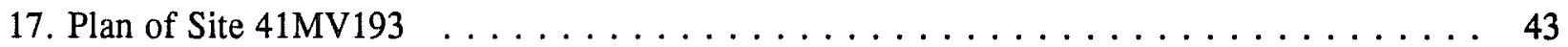

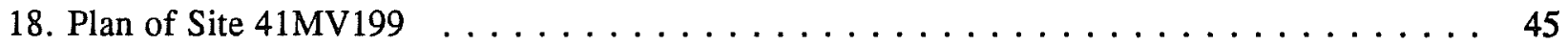

19. Schematic Plans of $41 \mathrm{MV} 139$ and $41 \mathrm{MV} 158 \ldots \ldots \ldots \ldots \ldots \ldots \ldots \ldots \ldots$

20. Schematic Plans of $41 \mathrm{MV} 167$ and $41 \mathrm{MV} 174 \ldots \ldots \ldots \ldots \ldots \ldots \ldots \ldots$

21. Schematic Plans of $41 \mathrm{MV} 175$ and $41 \mathrm{MV} 176 \ldots \ldots \ldots \ldots \ldots \ldots \ldots \ldots \ldots$

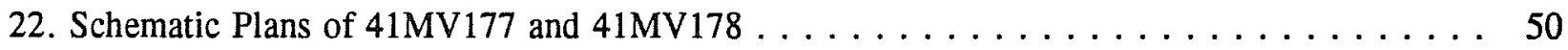

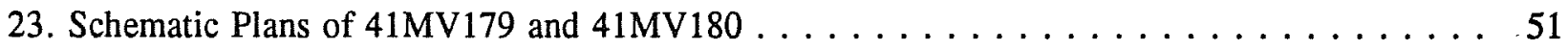

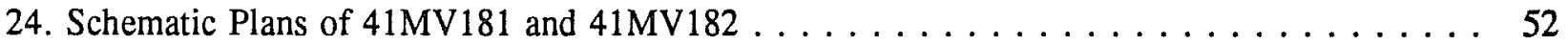

25. Schematic Plans of $41 \mathrm{MV} 183$ and $41 \mathrm{MV} 184 \ldots \ldots \ldots \ldots \ldots \ldots \ldots \ldots \ldots$

26. Schematic Plans of $41 \mathrm{MV} 188$ and $41 \mathrm{MV} 190 \ldots \ldots \ldots \ldots \ldots \ldots \ldots \ldots \ldots$

27. Schematic Plans of $41 \mathrm{MV} 191$ and $41 \mathrm{MV} 192 \ldots \ldots \ldots \ldots \ldots \ldots \ldots \ldots \ldots$

28. Schematic Plans of $41 \mathrm{MV} 194$ and $41 \mathrm{MV} 195 \ldots \ldots \ldots \ldots \ldots \ldots \ldots \ldots$

29. Schematic Plans of $41 \mathrm{MV} 196$ and $41 \mathrm{MV} 197 \ldots \ldots \ldots \ldots \ldots \ldots \ldots \ldots \ldots$

30. Schematic Plans of $41 \mathrm{MV} 198$ and $41 \mathrm{MV} 200 \ldots \ldots \ldots \ldots \ldots \ldots \ldots \ldots . \ldots \ldots$

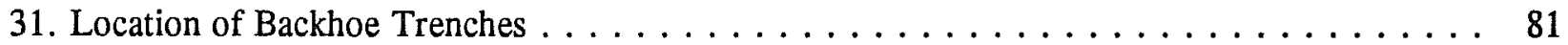

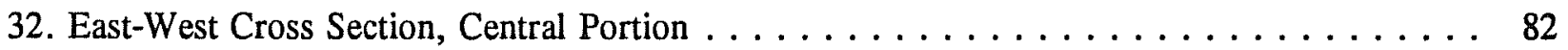

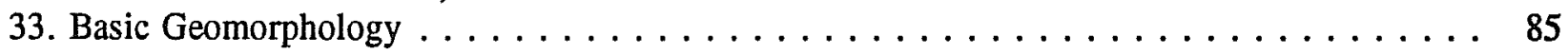

34. East-West Cross Section, Northern End $\ldots \ldots \ldots \ldots \ldots \ldots \ldots \ldots \ldots \ldots$

\section{LIST OF TABLES}

1. Numbers of Documented Archaeological Sites in Maverick and Proximate Counties in February 1992

2. Summary Data and Recommendations for Dos Republicas Project Archaeological Sites . . . 


\section{ACKNOWLEDGMENTS}

The Phase II investigation was expedited by the timely performance and friendly assistance of many persons. Hopefully, all are included here: Lisa Kost, mining engineer and project coordinator for Marston \& Marston, Inc., St. Louis, Missouri, who promptly provided maps and pertinent information to the Center for Archaeological Research (CAR) of The University of Texas at San Antonio when needed; John Moran, who acted as on-site representative for Marston \& Marston; the personnel of Carl Dickerson's office in Eagle Pass, Texas, including Carl and his brother Phillip, and Adolfo ("Fito") Garza, who arranged access to the permit area; Mario Ramirez, Special Agent with the United States Border Patrol in Eagle Pass, who provided information on area ranches; James and Hollis Kincaid of Sabinal, Texas, owners of the Kincaid Ranch, and their ranch manager Hodge Lord, who provided good company and kept us from getting lost, stuck in the mud, and snake bitten; Paul Hudson of Sabinal, who operated our backhoe with requisite skill and also dispatched threatening rattlesnakes with his Winchester rifle; David Shanabrook of Plano, Texas, project geomorphologist, for his expertise and patience; Dick and Jan Cartwright, managers of the La Quinta Inn in Eagle Pass, who provided red carpet accommodations within our budget; Herb Senne of the Eagle Pass Soil Conservation Service office, who provided information on area soils, hydrology, and plant species; Wil Baucom, County Extension Agent for Maverick County, who provided information on area vegetation and agriculture; Arturo Pine of the Eagle Pass Chamber of Commerce, who mailed us data on the local economy, geography, demography, and history; Michael J. Ritchie and Frank Barrientos, historians with the Fort Duncan Restoration Association, who provided in-depth historical background data on the area; and the residents, business owners, and public officials of Eagle Pass, who lived up to the Texas tradition by virtue of their enthusiastic hospitality, friendliness, and generosity.

The support, dedication, and hard work of the archaeological field crew, consisting of Maureen Brown, Nora DeLaO, Kevin Gross, Clinton M. M. McKenzie, and Gorden K. Wright of CAR; and the assistance of Anne Fox in the identification and analysis of artifacts from site 41MV199, are gratefully acknowledged. Wright also helped with artifact identification and manuscript review.

Special thanks are due to Thomas R. Hester, Director of the Texas Archeological Research Laboratory and Professor of Anthropology at The University of Texas at Austin, for his detailed review of the first manuscript draft. His review, based on his long-standing and intimate familiarity with the archaeology of south Texas and the Rio Grande Plain areas, was an invaluable contribution to this report.

Jack Eaton was the principal investigator during the fieldwork and write-up stages; Robert Hard was principal investigator during the final report production process. Marcie Renner was the technical editor, while Rachel Pullen and Cathy Heaslet worked their magic on the word processor. 


\section{INTRODUCTION}

In February and March 1992, the Center for Archaeological Research (CAR) of The University of Texas at San Antonio (UTSA) conducted a Phase II intensive archaeological survey for Marston and Marston, Inc., of St. Louis, Missouri, on a 1,092.69 ha (2,700 a) tract of land in Maverick County, Texas (Figures 1 and 2). Dos Republicas Resources Company, Inc., of Eagle Pass, Texas, had applied for a coal stripmining permit for the property with the Railroad Commission of Texas (RCT), thus necessitating the survey. The Texas Historical Commission, Department of Antiquities Protection (THC-DAP) recommended that the Phase II work consist of an intensive archaeological survey of the entire permit area as defined herein (Figure 2). Principal investigator for CAR was Jack D. Eaton, Acting Director. Herbert G. Uecker, technical staff assistant, supervised a field crew of five archaeologists during the onsite work: Maureen Brown, Nora DeLaO, Kevin Gross, Clinton M. M. McKenzie, and Gorden K. Wright.

The field investigation, subsequent analysis, and report preparation were performed according to specifications and requirements of: (1) the THC's (1981) Guidelines for Archeological Investigation of Mining Areas in Texas; (2) Section 106 of the National Historic Preservation Act of 1966 (including amendments and implementation regulations 36 CFR 800); (3) the National Environmental Policy Act and related regulations (50 CFR 4); (4) the regulations (as amended in 1987: 30 CFR, Chapter VII) of the Federal Office of Surface Mining Reclamation and Enforcement; (5) the Secretary of the Interior's Standards and Guidelines for Archeology and Historic Preservation (48 FR 44716); and (6) the memorandum of understanding (MOU; Bruseth 1991; Perttula 1991) between the THC's Department of Archeological Planning and Review and the Railroad Commission of Texas, Surface Mining and Reclamation Division. The MOU was instituted in 1991 to meet standards defined in the Federal Surface Mining Control and Reclamation Act of 1977 (52 CFR 4245) and the Texas Surface Coal Mining and Reclamation Act.

The elements of a Phase II investigation are standardized in the THC's Guidelines for Investigation of Mining Areas in Texas (Texas Historical Commission 1981:2-4); thus, the CAR investigation included the following procedures and phases: The files and libraries of CAR and the Texas Archeological Research Laboratory of The University of Texas at Austin (TARL-UT) were examined for background information on cultural resources within the mining permit area, Maverick and immediately surrounding counties, and the Rio Grande, Pecos, and Devil's River basin areas of southern Texas/northeastern Mexico (Figure 1; cf. Espey, Huston \& Associates 1979:Figure 1; Hester 1980:Figure 2.1, 1981:Figure 1; Black 1989:Figure 19). The background literature search at the TARL-UT facility was conducted by Herbert G. Uecker and Maureen Brown on February 11, 1992. The CAR data search was continued by Uecker throughout the project.

The portion of the permit property on the east side of the Southern Pacific Railroad track (Figure 2, Area A; approximately 433.43 ha [1,071 a]) was subjected to a simultaneous Phase I and Phase II surface reconnaissance and intensive survey. Also, an intensive (Phase II-type) investigation of the portion of the permit area on the west side of the railroad track (Figure 2, Area B; about 659.26 ha [1629 a]) was attempted. A Phase I surface reconnaissance survey of the latter was previously performed by Espey, Huston \& Associates, Inc. (EHA), Austin, Texas, branch (Espey, Huston \& Associates 1981). Twentyeight archaeological sites (41MV132, 41MV135-139, 41MV141-146, 41MV155-161, 41MV164-168, and 41MV170-173; Figure 3) were discovered and recorded in Area B during the 1981 survey. Limited subsurface testing (Phase II shovel and backhoe tests) was conducted by CAR in both areas and a geomorphological study of the permit area was performed (see Appendixes I and II). The on-site work was undertaken between February 17 and March 21, 1992. Laboratory analysis of artifacts, site 


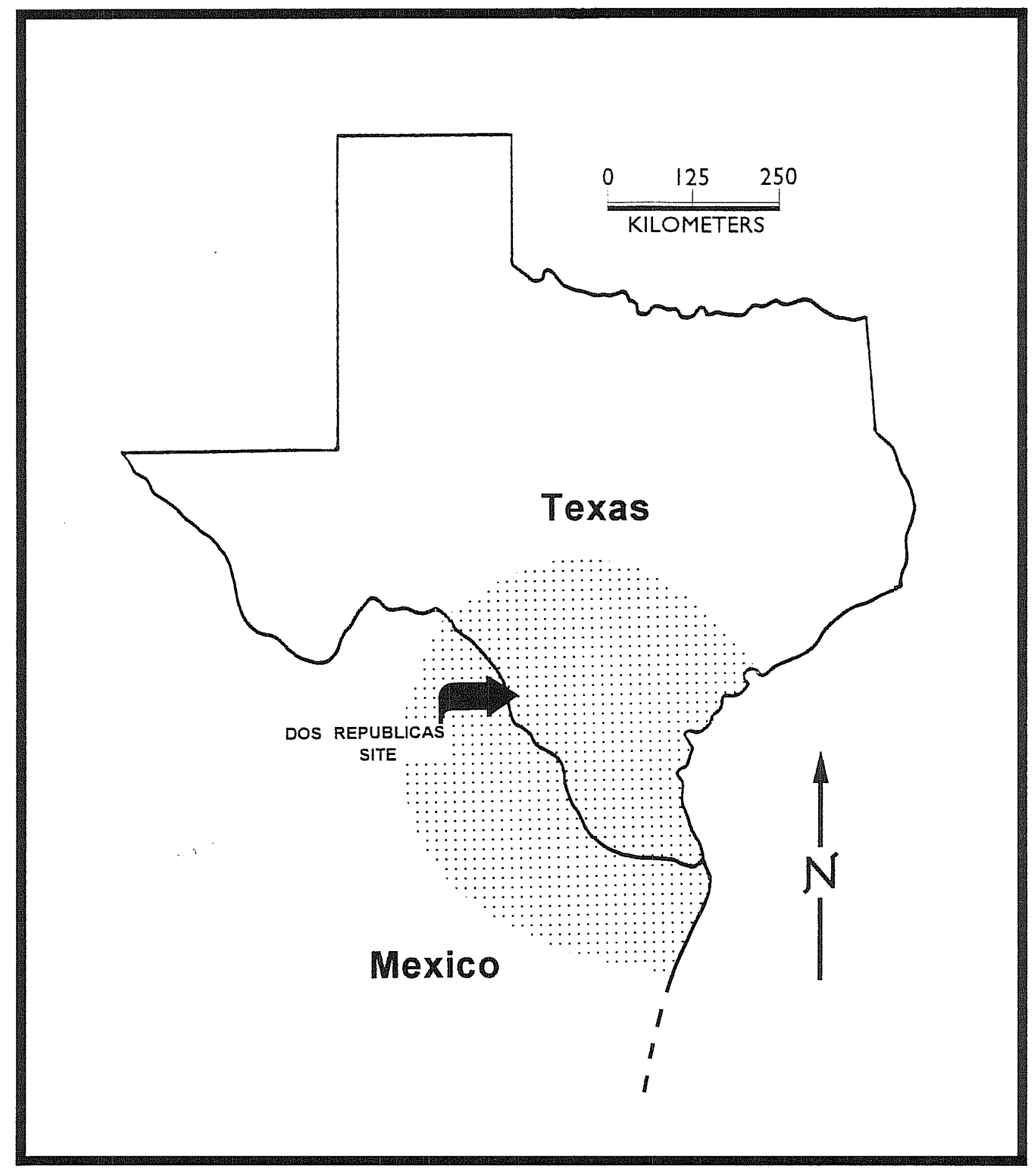

Figure 1. Location of the Dos Republicas Proposed Coal Mine. Shaded area is extent of the Southern Texas-Northeastern Mexico Archaeological Area (After Hester 1980:Fig 2.1). 
This page has been

redacted because it

contains restricted

information. 
This page has been

redacted because it

contains restricted

information. 
evaluation, report preparation, and initial editing began immediately after completion of the field work and continued until mid-August 1992, when the first manuscript draft was submitted to Marston and Marston. After review by Marston and Marston, the THC-DAP, and the RCT, the draft was returned to CAR for revisions and publication. 


\section{SCOPE OF WORK AND METHODOLOGY}

Background research prior to field work had indicated that the permit area probably contained several kinds of archaeological resources. Some of the first professional archaeologists to investigate similar areas of the Rio Grande Plain divided prehistoric (as well as some protohistoric [Hester and Hill 1975:19; Hill and Hester 1973] and Historic) Indian sites in the region into two broad categories: (1) riverine or gallery sites, and (2) upland or bower sites (Fox 1979:6; Nunley 1977:5-6; Nunley and Hester 1975:1314; cf. Hester 1980:57-86; Warren 1989b:12-15). The river-basin sites were often fairly conspicuous, large, open camps, known as middens (refuse piles) that occasionally had deep, well-preserved cultural deposits (Hester and Hill 1975:7). They were apparently multi-functional sites, and artifacts (primarily of stone, bone, and shell) found in them reflected patterns of long-term intermittent occupation, food processing and preparation, and waste disposal by small bands of nomadic hunter-gatherers.

Upland sites were believed to have been the locations of less extensive and shorter-term activities by the same groups of peoples (cf. Hester 1978:34, 1981:123 regarding finds of extensive, deeply buried, multiple-component upland sites in Live Oak and Zavala Counties). The artifacts found at the interriparian sites indicated that they were probably specialized activity areas; for example, animal and plant food processing stations or quarries where raw material for stone tool manufacturing was obtained. Due to the steeper terrain of the uplands, such sites were usually more severely eroded and deflated than lowland sites.

Although many Indian sites of both general types ranged in age from the Paleo-Indian period (ca. 11,0008000 before present [B.P.; calculated by convention from 1950]) to the post-European contact period (A.D. 1528 to present), those dating from the Late Archaic (ca. 3500-1200 B.P.) through the Late Prehistoric (ca. 1200-422 B.P.) periods constituted a clear majority. Summary descriptions of these cultural periods are found in Hester (1980:28-31) and Turner and Hester (1985:47-53,Figure 19).

Historic period sites could also have been present in the permit area. The Historic period in Texas began in the early-sixteenth century (Hester 1976b:5) when the Spanish explorer Alvar Nuñez Cabeza de Vaca, who was shipwrecked off the Florida coast in 1528, subsequently (for the next eight years) walked back to Mexico across the Gulf Coastal Plains and possibly through south Texas (Campbell and Campbell 1981). He was the first European known to have traversed those areas.

The middle-Rio Grande area was part of the traditional home range of the Jumano and Coahuiltecan Indian groups during early historic times, and was heavily infiltrated by southern Plains tribes such as the Apaches and Comanches by the late-seventeenth century. Tonkawa Indians from central Texas also allegedly visited the area intermittently (Sjoberg 1953; cf. Newcomb 1960,1961). In addition, both the Kickapoo and Seminole Indians made the Texas/Mexico border near Eagle Pass their home since about the mid-nineteenth century (Fox 1983:48; Hester 1980:56,1989:84). Many Spanish expeditions passed through Maverick County and several came through or near Eagle Pass from the sixteenth through the eighteenth centuries. There was also the probability of encountering archaeological sites of nineteenth and early twentieth-century age such as Hispanic or Anglo-European settlements, and mining or railroadrelated sites.

Advance information regarding the archaeology of the Dos Republicas proposed coal mine site was available to the CAR field team. The sources consulted indicated it would be very difficult to recognize the boundaries of prehistoric sites due to the ubiquitous chert gravels and stone tool chipping debris on the surface in the area (Espey, Huston \& Associates 1981; Mike Davis, Dan Prikryl, personal communications 1992; cf. Hester 1980:57). An effort was made to maintain reasonable objectivity by 
basing spatial definitions of sites on densities of surface cultural material and on landform associations; however, due to the problems described by previous investigators, intuition also played a significant role in the process of site boundary delineation.

Shovel tests done by the EHA team had indicated the existence of very thin cultural deposits at most sites with only moderate depths $(<1.0 \mathrm{~m}$ at best and usually $<0.5 \mathrm{~m})$ being present at exceptional sites. Within the permit area as redefined for the CAR investigation, virtually no primary cultural strata had been encountered during the EHA survey. It was apparent from examination of topographic maps and aerial photos that much of the land within the Dos Republicas permit tract had been disturbed by modern human activities such as cattle ranching, land clearing, irrigation, brush control, and soil conservation practices. It was also learned from local sources (government officials, land owners, and ranch hands) that surface collecting of artifacts had taken place for decades at many sites in the area.

Thus, a relatively flexible approach was adopted during the investigation. Although a formal transect section-and-grid plan was designed for the entire coal mine permit area, extemporaneous alterations of the plan were frequently made. The net result was that approximately 80 percent of the ground surface of Area A was intensively examined on foot. About 10 percent of the Area A surface was in impenetrable thorn-brush or extremely dense ground vegetation. Virtually all the impenetrable portions not examined during the CAR Phase II work were confined to the portion of the Elm Creek floodplain in the southern half of the permit tract. These areas are known to have been radically disturbed by midtwentieth-century Soil Conservation Service cutting-and-terracing projects (Herb Senne, personal communication 1992; cf. Shannabrook: p. 84 of Appendix I). Due to the occurrence of inclement weather during the survey and resulting access delays, and also due to the amount of time required to properly record the relatively high volume of sites ( 27 not previously documented) and artifacts found in Area A, about 10 percent of the area was not surveyed (Figure 2). This unsurveyed portion of Area A contains roughly 40 ha (100 a) of the floodplain of Elm Creek; its investigation should be included in any future work.

Since EHA had previously conducted a Phase II-type survey of Area B and because time became a critical factor during the Dos Republicas Project fieldwork, it was decided (after consultation with the THC-DAP) that an intensive pedestrian resurvey of that area would be deferred until the next phase of work was undertaken. To obtain at least a tentative grasp of the archaeological merits of Area B, six sites (41MV139, 41MV158-161, and 41MV167) were located, shovel tested, and reassessed during the CAR work. The sites were selected because of their size, depth, and quality of cultural deposits, and ease of physical access as indicated on the EHA site forms on file with TARL. The net finding of this procedure was that 41MV160 and 41MV161 apparently had well-preserved cultural deposits of substantial depth and were therefore recommended for further work (see Conclusions: Commentary and Recommendations).

The walking survey in Area A was conducted essentially as follows: At the start of each transect, the five-member survey team was positioned on $20 \mathrm{~m}$ intervals and oriented on bearings according to the section-and-grid plan. The team then maneuvered across the landscape on foot, following the bearings within fairly narrow zig-zag paths, searching for surface outcrops of cultural material or areas likely to contain buried archaeological deposits. Particular attention was paid to floodplains, levees, and alluvial bars in riparian zones, and to natural benches, toes of slopes, and promontories in the uplands. Prominent or newly exposed erosional surfaces such as those found in the banks of rills, arroyos, microscarps, and stream channels were also given extra scrutiny. Accuracy of transects was maintained by the personnel walking the outermost lines, who frequently checked bearings and landmarks, compared them with topographic maps and aerial photos, and communicated with walkie-talkies. Biodegradable flags were used to temporarily mark transect edges to avoid overlapping or omissions. 
Sites and isolated artifact finds were usually documented as they were discovered by measuring azimuths and distances to local geographic references, such as the railroad track, windmills, permanent deer blinds, or engineering benchmarks. Whenever possible, geometric triangulation with a Brunton pocket transit was employed. Locations of the finds were plotted on both an aerial photograph and the Deadman's Hill quadrangle topographic map.

The survey team examined the surface of each prospective site, pin-flagging exposed artifacts and features until the extent of the site had been reasonably well defined. When site status was determined, a controlled surface examination and artifact collection was made. Locations of selected artifacts (primarily time-diagnostics, i.e., recognizable types of known ages and cultural affiliations) and archaeological features were plotted on scale maps with reference to a site datum, and representative artifact samples were bagged by provenience. The artifacts were taken to the CAR laboratory and cleaned, labelled, studied, and prepared for ultimate disposition by standard procedures.

Several shovel tests (averaging $30 \mathrm{~cm}$ in diameter) were excavated within each site boundary, usually to depths of about 50-75 cm. Although the quantities, locations, and depths varied (based on the surface evidence present and the results of initial tests), at least two shovel tests were dug at most sites. During the shovel tests, densities, depths, relative positions, and other noticeable characteristics of natural and cultural soil strata and inclusions were documented. In all cases, soil samples from each stratum distinguished were collected.

Because positive results were obtained during surface examinations and shovel tests at seven sites (41MV160, 41MV185, 41MV187, 41MV189, 41MV192, 41MV195, and 41MV200), they were selected for limited backhoe testing. At least one backhoe trench was excavated in what appeared to be the most promising area of each of the sites chosen. The average size of the trenches was about six meters in length and $0.6 \mathrm{~m}$ (one backhoe bucket) in width; average depth was approximately $2.5 \mathrm{~m}$. All cultural material and strata revealed in the backhoe trenches were recorded, and at least one profile face was trowelled, examined, and photographed.

After completion of the excavations, results were spot-evaluated and tentative recommendations for each site were noted. When a decision was made in the field to recommend further work at a site, the site was marked by driving a three-quarter inch diameter steel stake into the ground at the mapping datum location and attaching an aluminum tree tag to the stake with galvanized wire. The tag was labelled by scribing the aluminum with the initials of the research organization (CAR), the name of the project (Dos Republicas), the temporary site (TS) number, and the date.

Two sets of field notes were produced during the investigations. These included a notebook with standard site, unit-level, feature, photograph, bag, and unique-item forms and logs backed up by tape-recorded observations. Both black-and-white and color photographs were frequently taken. Samples of dominant floral species were collected at site $41 \mathrm{MV} 160$ and were identified by personnel of the Maverick County Soil Conservation Service and the Maverick County Extension Horticulturist's office. 


\section{LOCATION, HISTORY, AND GENERAL CHARACTERISTICS OF THE PERMIT AREA}

The following description of the Dos Republicas Project property relates its condition as observed by CAR archaeologists in 1992. The proposed coal-mining area was within several active cattle ranches along Elm Creek about eight kilometers north of Eagle Pass, Texas (population 24,000+) between U.S. Highway 57 and Farm-to-market Road 1588 (Thompson Road). The source of Elm Creek, an ephemeral tributary of the Rio Grande, was about $35 \mathrm{~km}$ to the north. Due to abnormally high amounts of rainfall over the previous several months, Elm Creek was flowing and crested about one meter above its channel floor during the CAR field work. The channel averaged several meters in width and depth. Along much of its length, the channel floor contained a thin, narrow band of mostly limestone gravels and cobbles; the banks were lined primarily with sandy-clay loams that contained few exposed stones and other visible inclusions. Elevations above mean sea level within the permit boundary ranged from approximately $225-$ $250 \mathrm{~m}$.

The tract was geographically divided on a rough north-south axis by a segment of the Southern Pacific Railroad. The Kincaid Ranch occupied much of Area A, but the area also encompassed all or parts of several smaller agricultural tracts such as the El Huisache Ranch. The Kincaid Ranch, owned by brothers Hollis and James Kincaid of Sabinal, Texas, contained over 6,880 ha (about 17,000 a). The portion of the Kincaid property within the project area (about 240 ha or 600 a) had been part of an active cattle ranch owned by family members since about the mid-1940s. Area B was also comprised of portions of several ranches, including the Los Cuatros Ranch.

Although its history as a Texas landmark (Paso del Aguila) dates from the early-eighteenth century, the city of Eagle Pass was officially founded in 1850 at a ford of the Rio Grande near the confluence with the Rio Escondido. The ford is along the Camino Real between San Antonio and Saltillo and Monclova, Mexico, and was used by several parties of Spanish explorers and by the Frenchman Louis Juchereau de St. Denis between about 1713 and 1727 (Pingenot ca. 1990). Brune (1981:map inserts) shows that approximately 15 Spanish expeditions passed through the Eagle Pass/Maverick County areas between 1542 and 1766. Eagle Pass was also a destination of several significant trading and military expeditions during the first half of the nineteenth century, including those of Philip Nolan, James Long, Zebulon M. Pike, General Antonio López de Santa Anna, and General James E. Wool (Stephens and Holmes 1989).

The Spanish missions San Juan Bautista, San Francisco Solano, San Bernardo, and a presidio were established between 1699 and 1703 near Guerrero, Coahuila, Mexico (cf. Weddle 1968a, 1968b). These early footholds of European-style civilization provided a nucleus for initial human settlement and urban development in the Texas Middle Corridor area (Pine 1990). The influence of the Spanish crown on the area's political and economic structure did not subside until the Mexican Revolutionary period of the early-nineteenth century.

Throughout much of the eighteenth and nineteenth centuries, area economics and development focused on ranching, irrigation agriculture, and trade between Mexico and the United States. The human population of Maverick County had attained a fairly constant, though moderate, rate of growth by 1860 that continued until about 1970. From 1970 to 1980 , the population skyrocketed, with a 78 percent increase for Maverick County and a 54 percent increase for Eagle Pass. The fringe zone just outside of Eagle Pass grew at the truly impressive rate of 266 percent during that decade. These remarkable population increases have been attributed primarily to the burgeoning international trade industries of the area (Eagle Pass Chamber of Commerce ca. 1991). In the early 1990s, the population of Maverick County was estimated to be about 90 percent Mexican-American, including 37 percent foreign born. 
After the Texas Revolution, Eagle Pass became a military post with the establishment of Fort Duncan during the late 1840s and early 1850s. Fort Duncan was active during the Civil War, the Mexican Revolutionary period from 1910 to 1916, and World War I; thus the influence of the military in the area continued to be significant until about 1920. The Southern Pacific Railroad was extended to the area by 1882 and. as the Industrial Revolution came into full bloom in Europe and the Americas, Eagle Pass grew into a sizeable border trading and manufacturing town. Coal mining began in Maverick County in the late-nineteenth century and substantial petroleum extraction began in the mid-1950s.

The following information on the history of coal mining in the area was condensed from Evans (1974). Although coal was mined near Eagle Pass as early as 1849 by soldiers from Fort Duncan, large-scale commercial extraction first began in the region during the mid-1880s. Major production was initiated at the Eagle mine (located just west of Piedras Negras, Mexico) and at the Hartz mine (located just northwest of Eagle Pass), and continued until the mid-1920s. By the mid-twentieth century, the Eagle Pass/Maverick County coal field was considered one of the three largest in Texas, with estimated total volume at 525 million short tons.

In the early 1990s, the economic infrastructure of Eagle Pass/Piedras Negras was based on the transportation, trade, mining, petroleum, and manufacturing industries, augmented to some extent by ranching, agriculture, hunting, fishing, and tourism. Pine (1990:62-71) documented several decades of slow but steady growth of twin plants or maquiladoras and of the general economy of the border zone in the vicinity. He apparently believed that, as an important subset of the Monterrey-Laredo-Austin industrial corridor, the zone was on the cusp of a major economic and demographic upsurge. This was substantiated to a large extent by the aforementioned rapid population increases that occurred in the area. Several ongoing or pending capital improvements spearheaded by the Maverick County Development Corporation also tended to support Pine's allegation: the six million dollar expansion of the Eagle Pass port of entry, a tenfold increase in capacity for customs clearance of imported goods, the imminent construction of the new International Bridge II and associated private sector developments, increased rail facilities, the relocation and expansion of Maverick County's International Airport, and additional air service from both the United States and Mexico to the area.

More information on the history, economy, cultural geography, and cultural and historical resources of Eagle Pass, Piedras Negras, Maverick County, and the Texas Middle Corridor is available in publications or writings by Black (1989); Campbell (1979, 1988); Espey, Huston \& Associates (1979, 1981); Hester (1975a, 1975b, 1976a, 1976b, 1977a); Hester (ed. 1976); Nunley (1977, 1989:191-208); Pine (1990); Pingenot (ca. 1990); Potter (1990); Ruecking (1953, 1955a, 1955b); Salinas (1990); Weddle (1968a, 1968b); and from the Eagle Pass Chamber of Commerce. 


\section{NATURAL SETTING AND NATURAL HISTORY}

From a regional physiographic and geologic perspective, the permit area is within the Gulf Coast Physiographic Province or Gulf Coastal Plain as described by Fenneman (1931). It is just south of the Balcones Escarpment and Canyonlands, a series of northeast-to-southwest trending fault scarps and associated basin-and-range-like features that began forming about 21 million years ago (m.y.a.) during the Miocene geologic epoch. The Gulf Coastal Plain is a broad, gently rolling lowland of south and southeastern North America that is dissected by numerous streams and rivers that drain into the Gulf of Mexico. The portion of the region within Texas has been succinctly described, "this entire section of Texas is popularly known as the 'Monte,' a vast expanse of undulating plain and rocky outcrops of low relief, uniformly covered with thorny brush. It is also called a 'mesquite savannah' by geographers, although many small trees other than mesquite bear thorns and are adapted to the low rainfall, high humidity, and great heat of this region" (Suhm et al. 1954:135; cf. Montgomery 1978:3-14).

The area's geoclimate has been described as subtropical or mesothermal steppe, semiarid or subhumid and megathermal, characterized by mild, dry winters and hot, humid summers (cf. Chambers 1946:113; Russell 1945; Thornthwaite 1948). In the Dos Republicas Project vicinity, annual rainfall averages about $500 \mathrm{~mm}$ and its occurrence generally conforms to the bimodal pattern (with peaks in May and September) typical for all of south and central Texas (Eagle Pass Chamber of Commerce ca. 1991). Nevertheless, over the short-term there is a great deal of variability to the rainfall pattern of the area and the adjoining Balcones Escarpment and Canyonlands areas have experienced world-record precipitation events (cf. Caran and Baker 1986; Slade 1986).

The Gulf Coastal Plain is underlain by the Gulf Coast Geosyncline, an extensive geologic basin (Renfro et al. 1973). The upper part of the geosyncline is mostly soft calcareous rock strata and clay-sand sediments deposited since the Late Cretaceous/Early Tertiary uplift of the southern Rocky Mountains about $65 \mathrm{~m} . y$. . T. The basin as a whole is tens of thousands of feet deep near and under the Gulf of Mexico, and tapers to shallower depths toward the north (Mueller 1983:82).

On a more local scale, the permit site is located on the West Gulf Coastal Plain, known also as the Rio Grande Plain (cf. Fenneman 1931; Hester 1971; Inglis 1964; Johnson 1931; Montgomery 1978:3-11; Mueller 1983:83). Within this sub-area, the large-scale topography grades from essentially level in the more northern and eastern zones to relatively dissected and rugged in the southern and western zones near the Rio Grande and its feeder streams (Chambers 1946:112). A salient characteristic of the local microtopography is the broad shallow stream valleys which gradually rise to the surrounding uplands (Smith et al. 1940:2).

Subsurface geology (bedrock or parent materials) of the Dos Republicas permit tract consists of limestones of the Kemp, Corsicana, Nacatoch, Marlbrook, Pecan Gap, Wolfe City, or Ozan formations of the Navarro and Taylor groups of the Upper Cretaceous or Gulfian series (about 90-70 million years in age; Renfro et al. 1973). Evidently the most economically viable coal in the area is sub-bituminous cannel coal from the Olmos Formation (upper-Cretaceous geologic period), located at average depths of 10-20 $\mathrm{m}$ below the surface, with maximum seam thicknesses of about two meters (Espey, Huston \& Associates 1981:1-1). According to Evans (1974:2), "cannel coal is a variety that is not considered in most classification schemes. Composed of spores, pollen, algae, leaf cuticles, or other waxy, resinous substances, cannel coals are distinguished from other coal varieties by massive structure, fine-grained texture, gray to black color, greasy luster, and conchoidal fracture." 
Most of the geologic surface exposures on the Rio Grande Plain are comprised of Quaternary period sediments: (1) chert and limestone gravels, sands, and clays that have been eroded from the Balcones tablelands to the north and transported to the area via the many spring-fed rivers and streams cutting across the escarpment, and (2) calcareous soil fractions containing inclusions of exotic silicates of igneous origins (notably quartzite, basalt, and andesite) abraded from the southern Rocky Mountains of west Texas, northern Mexico, and southern New Mexico. Since the area's soils have poor infiltration rates due to their high clay content, flooding frequently occurs during even modest rainfalls. Much of the land surface has been repeatedly altered by natural colluvial (sheet) erosion, microscarping, rilling, and arroyo formation. These processes have had a flattening or deflating influence on most of the archaeological sites in the area (cf. Newton 1968:20, Figure 2).

The U.S. Department of Agriculture's Soil Conservation Service general soil map of Maverick County indicates the soils within the Dos Republicas permit tract are primarily of the Elindio-Montell and Jiminez-Olmos-Zapata associations. The former are described as nearly level to gently-sloping, deep silty-clay loams and clays; the latter are characterized as rolling to undulating, shallow to very-shallow loams and very-gravelly loams (U.S. Department of Agriculture 1977; cf. Montgomery 1978:7-9). Hester and Hill (1972:39) were advised by former Soil Conservation Service agents Jack Stevens and Wayne Hamilton that the Montell component is one of several in the Rio Grande Plain area containing vertisols (cf. Duffield 1970). Vertisols are often quite turbaceous, and therefore have the potential to radically disrupt otherwise well-preserved or well-stratified archaeological deposits. In spite of the presence of vertisols at the Holdsworth site (41ZV14; a prehistoric Indian floodplain midden site with Archaic and Late Prehistoric components located in southeastern Zavala County), no deleterious effects upon cultural strata that were attributable to soil type were observed during archaeological excavations at the site (Hester and Hill 1972:61).

The chert and limestone gravels on the Rio Grande Plain which are derived primarily from the Edwards and Glenrose limestones of the Balcones Escarpment are known as the Uvalde Gravels or as the Uvalde Formation (Loomis et al. 1992). The Uvalde Gravels is the principal gravel outcrop that covers almost the entire surface of the area (some alluvial zones excepted) north of the Rio Grande to the southern edge of the escarpment. It is particularly noticeable as relatively dense deposits capping the secondary terraces or hilly uplands (cf. Hester and Hill 1972:37). In the alluvial zones of the Rio Grande and other major rivers of the area, the gravels with a higher proportion of exotic silicate rocks derived principally from the southern Rocky Mountains are known colloquially as the Rio Grande Gravels. These chert and other silicate gravels were of great importance to the local prehistoric human groups as raw material for stone tool manufacturing, for heating elements in earth ovens, and for a multitude of other uses (cf. Hester 1989:119-120 and Hester et al. 1991 regarding the cultural importation of exotic lithic materials to the Rio Grande Plain and Trans-Pecos Texas areas from remote sources during prehistory).

Blair (1950) included the western portion of the Gulf Coastal Plains in the Tamaulipan Biotic Province and characterized the principal vegetation there as thornbrush. Riskind and Diamond (1988), following the classification scheme of the Lyndon B. Johnson School of Public Affairs (1978), assigned the area to Texas Natural Region 6: South Texas Brush Country. Although it was not feasible to present a detailed description of the area's modern phytogeography in this report, several comprehensive publications on the subject are available and the interested reader is referred to them directly (cf. Bowers 1989; Bye 1983; Elanco Range Products ca. 1990; Fischer 1989; Inglis 1964; Powell 1988).

It is noteworthy that numerous researchers have recognized modern vegetation in the area is differentially distributed between uplands and lowlands (cf. Espey, Huston \& Associates 1981:2-3; Hester 1971:1-2, 1976b:2, 1981:2; Montgomery 1978:13; Nunley and Hester 1966:236). The upland floral assemblages 
are generally comprised of relatively sparse stands of certain species of cacti and (mostly xeric and sclerophyllous) woody shrubs and trees, otherwise known as chaparral (Smith et al. 1940; Newton 1968:18). The floodplains and creek channels are densely populated with different species of cacti and (mostly mesic) deciduous woodlands amidst thick vines and groundcovers.

No formal botanical, ethnobotanical, or paleobotanical studies of the Dos Republicas Project area were performed during Phase II, but many of the floral species previously identified in the general area are listed in writings by Holdsworth (1972:65-69) and by Espey, Huston \& Associates (1981:2-3). Some of the native plants seen within the Dos Republicas Project site by the CAR field team in early 1992 were cedar elm; persimmon; hackberry; live oak; mesquite; huisache; blackbrush, catclaw and twisted acacia; guayacan; cenizo; guajillo; granjeno; lotebush; border palo verde; whitebrush; bacharrus; prickly pear; tasajillo; yucca (Spanish dagger; cf. Hill et al. 1972); horsecrippler cactus; and sacahuista. These species were distributed within several microenvironments and ecotones, but project time limitations did not allow for systematic examination or documentation of these phenomena. Although details have yet to be determined, there is virtually no doubt that similar ecotones existed during prehistory and were preferred living sites of humans and of many other animals as well (cf. Hester 1971:3-9, 1976a:85, 1976b:2,5-8, 1981:123-125; Hester and Hill 1975:20).

The fact that a large variety of animal species has occupied the area since the end of the Pleistocene geologic epoch (ca. 12,000 B.P.) has been well documented through archaeological studies (cf. Eaton 1975:37-39; Hester 1978:38,46, 1980:140-141; Hester and Hill 1975:25-29). Native fauna observed during the CAR field work included white-tail deer; javelinas; jackrabbits; cottontail rabbits; wild turkeys; quail; doves; roadrunners; buzzards and several unidentified species of hawks; rattlesnakes; several species of mice, lizards, and turtles; and miscellaneous unidentified small game animals and avifauna. Many species were present in abundant numbers. A few feral hogs were sighted, and numerous armadillos (though not seen during the CAR survey) were also known to inhabit the area.

Scientific research has revealed details of the long-term environmental evolution of northern Mexico and southern Texas (cf. Alexander 1970; Brown 1991; Bryant and Holloway 1985; Bryant and Shafer 1977; Dibble 1965; Inglis 1964; Marmaduke 1978; Nance 1972; Shafer 1986:34-43). The following synopsis of the natural history and paleoenvironment of the Rio Grande Plain area is derived from data gathered in the latter areas and includes only the period most relevant from a cultural-resource perspective (the terminus of the last ice age or Pleistocene geologic epoch to the near-present; cf. Black 1989:13-16; Hester 1976b:2-3, 1981:120-121; Montgomery 1978:12-14).

As melting of the northern-latitude ice caps of North America accelerated from about 18,000 to 12,000 B.P., the climate changed gradually from temperate to subtropical. Simultaneously, the sub-mountainous interriparian vegetation changed generally from a mesic, deciduous woodland/tall-grass savanna mosaic, or forest parkland, to a mixture of xeric thorn brush and short-grass prairies. The lower mountain slopes were initially verdant steppe grasslands. As gradual desiccation of the landscape occurred, the tops and higher slopes retained a boreal climate that supported piñon or ponderosa pine forests interspersed with a few patches of firs and spruces. River valleys became refuges for the last vestiges of dense deciduous woodlands where understories of mesic herbaceous shrubs, vines, and groundcovers flourished. As the warming trend continued into the last few thousand years B.P., invader species such as mesquite, huisache, prickly pear, and similar thornbrush (cf. Bowers 1989; Elanco Range Products ca. 1990; Fischer 1989; Powell 1988) became increasingly prevalent on the Coastal and Rio Grande Plains and juniper heavily infiltrated the Balcones Escarpment and Canyonlands. Fully developed deserts such as the Chihuahuan, located only a few hundred kilometers west of the middle-Rio Grande area, came into being (cf. Barlow et al. eds. 1986; Powell et al. eds. 1990; Wauer and Riskind eds. 1974). 
Significant changes in the area's animal life also occurred (cf. Espey, Huston \& Associates 1979:Table 3): Ice-age proboscidians (mammoths and mastodons); giant sloths; ancient forms of bison and camels; and unusually large varieties of predators including bears, American lions, sabre-toothed cats, and direwolves were apparently fairly abundant in the area at the beginning of the period, but largely disappeared by about 10,000 to 8,000 B.P. As the lush tall-grass steppes and prairies were transformed into expanses of short grass and thornbrush, antelope diminished to near-extinction and prairie dogs left the area. Very late in the chronology, deer, jackrabbits, and cottontails proliferated; and armadillos and javelina moved into the area from northern Mexico and gradually became established species (Hester and Hill 1975:17; Hester 1978:38, 1981:121). Sizeable populations of the modern (post-glacial) species of bison occupied the area intermittently after about 2,500 B.P. In the early 1990s, many species of small mammals, reptiles, and amphibians, and probably hundreds or perhaps even thousands of species of insects inhabited the area. For additional information on the plants and animals of the South Texas Plains, northeastern Mexico, and the Chihuahuan desert region, the interested reader is advised to consult literature by Barlow et al. (eds. 1986), Bowers (1989), Elanco Range Products (ca. 1990), Fischer (1989), Hester (1980:140141), Holdsworth (1972), Powell (1988), Powell et al. (eds. 1990), Swepston and Hailey (1991), and Wauer and Riskind (eds. 1974),

Humans affected the ecology of the area from the very beginning of the period. Throughout most of the sequence, their hunting-and-gathering lifeways and stone tool technologies simultaneously depleted the landscape and its natural inhabitants in some ways and helped to renew them in others. Until human populations and influence increased to a critical point during the post-European contact period, permanent alteration of the environment was minimal. Prior to the arrival of Europeans, only relatively small bands or populations of nomadic Indians periodically depleted microenvironments or ecological niches, usually allowing sufficient time between forays for the land to recover from their exploits.

The Europeans brought in urbanism and its large, concentrated human populations; began the practices of extensive agriculture and stockraising (employing deep-well irrigation that substantially depleted both surface-water and groundwater) in the rural zones; nearly eradicated such natural predators as bears, Mexican jaguars, cougars, wolves, coyotes, and alligators; eventually fenced the prairies; and suppressed range fires (cf. Hester 1976b:3,1978:38). These introduced conventions diminished biodiversity, encouraged overpopulation of white-tailed deer and small prey species such as jackrabbits and cottontails, promoted overgrazing that reduced natural soil stability and fertility, and ushered in the rampant secondary growth of thornbrush so prevalent in the area in later times. From the 1950s to the early 1990s, the use of modern scientific land management practices such as soil terracing, brush chaining, root plowing, and controlled burning began to ameliorate some of these adverse effects but simultaneously devastated literally thousands of archaeological sites within the area (Hester 1978:35, 1981:119-120). Hopefully, due to such ongoing attempts to restore ecological parity, the prospects for maintaining a stable and salubrious environment in the area well into the future will be assured. 


\section{PREVIOUS CULTURAL INVESTIGATIONS AND ANALYSES}

By the time of the CAR Dos Republicas survey, numerous archaeological sites in Maverick and nearby counties had been documented (Table 1). Systematic cultural resource studies were undertaken from the mid-1960s to the early 1990s in the central western Texas/Rio Grande Plains regions. The majority of the investigations occurred in three subregions: the Big Bend, the Lower Pecos Canyonlands, and the Rio Grande Delta (cf. Adams et al. 1975, 1976, 1977; Brown 1979; Campbell 1979, 1988; Eaton 1975; Espey, Huston \& Associates 1979, 1981; Fox 1979; Hester 1975c, 1977a, 1977b, 1978; Hester and Hill 1972; Hester et al. 1973; Hill and Hester 1971; Huebner 1991; Nunley 1989; Nunley and Hester 1966, 1975; Potter 1990; Ruecking 1953, 1955a, 1955b; Sobolik 1991).

Table 1. Numbers of Documented Archaeological Sites in Maverick and Proximate Counties in February 1992 (Source: Texas Archeological Research Laboratory, The University of Texas, Austin).

\begin{tabular}{|c|c|}
\hline COUNTY & $\begin{array}{c}\text { NUMBER OF } \\
\text { SITES }\end{array}$ \\
\hline \hline Maverick & 173 \\
\hline Dimmit & 123 \\
\hline Kinney & 50 \\
\hline Uvalde & 348 \\
\hline Webb & 349 \\
\hline Zavala & 343 \\
\hline
\end{tabular}


Thus, a substantial volume of both technical and non-technical literature on the archaeology and history of those areas was produced. Few state-of-the-art investigations had occurred in the permit area or immediate vicinity, but important treatises on the archaeology of South Texas (Hester 1980), the Rio Grande Plain (Hester 1976b), and the middle-lower Rio Grande area (Hester and Eaton 1983) were presented. Recently investigators have discussed the cultural inventory, culture history, archaeological theory, and research goals for the surrounding regions (cf. Black 1989; Gomez 1990; Hester and Eaton 1983; Salinas 1990; Shafer 1986; Turpin 1991; Turpin ed. 1991).

In an early attempt at analysis, Suhm et al. (1954:135-143) distinguished three stages within the culture history of the Southwest Texas archaeological region (Figure 1), a broad segment of the plains of southern Texas and northern Mexico that includes the Dos Republicas Project study area: PaleoAmerican (beginning in North America at an unknown time and continuing until about 5000-4000 B.C.), Archaic (4000 or 3000 B.C. to between A.D. 1 and 1000), and Historic (European contact to present). Following the McKern Taxonomic System (McKern 1939) and Kriegerian type concept (Krieger 1944, 1956), Suhm et al. divided the Archaic stage in the area into an earlier Falcon focus which, apparently with only slight changes in tool forms, evolved into the Meir focus. These divisions were based on interpretations of artifacts (projectile points and other stone tools) gathered mostly from surface cultural deposits by local avocational archaeologists and relic collectors. The few archaeological excavations in the area had been confined to the immediate vicinity of the Rio. Grande, and had focused on sites within the Zapata and Rosita terrace deposits (Suhm et al. 1954:137).

In the late 1960s, Newton (1968:Figure 3) attempted to develop a projectile point chronology for the area compatible with the general cultural chronology of Suhm et al. (1954), but Hester (1976b:4) suggested that more empirical data was needed to make both schemes more credible. Subsequent renditions of the culture history of the Rio Grande Plain area found during the CAR literature search (cf. Black 1989:39,48-57,61; Hester 1980:156; MacNeish 1958; Montgomery 1978:15) were largely inconclusive. At this writing, the formulation of a cogent and succinct prehistoric cultural chronology and technological typology for the middle-Rio Grande area apparently has yet to be achieved, and some important questions about the definition of the culture area seem to be unanswered (see Conclusions: Research Problems and Design for Future Work).

Systematic problem-oriented archaeological investigations in the South Texas Plains area proliferated during the mid-1960s and throughout the 1970s with the efforts of Thomas R. Hester (Director of CAR from 1974-1987 and, after 1987, Director of TARL) and various colleagues. The Hester and CARassociated projects most relevant to the prehistory of the Maverick County/Eagle Pass areas were comprehensive surveys and excavations of Indian sites located in major stream and river valleys of Dimmit, Starr, and Zavala Counties (cf. Fox 1979; Hester 1978; Hester and Hill 1972; Hill and Hester 1971; Montgomery 1978; Nunley and Hester 1966,1975). Those studies and similar ones undertaken under Hester's aegis in other areas of South Texas during the same period resulted in the forging of several important theoretical syntheses (cf. Hester 1971, 1974a, 1975a, 1975b, 1976a, 1976b, 1980, 1981; Hester ed. 1976; Hester and Hill 1975).

Cultural resources in Maverick and surrounding counties have also been documented in appreciable detail. In 1975, the National Endowment for the Humanities funded a major archaeological and ethnohistorical investigation of the area along both sides of the international border near Eagle Pass/Piedras Negras and in Guerrero, Mexico. The project, undertaken by UTSA and directed by Richard E. W. Adams, focused on the Spanish gateway missions and also on the prehistoric archaeological sites along the Rio Grande. It amassed a significant volume of data relevant to the management of the area's cultural resources (cf. Adams et al. 1975, 1976, 1977; Eaton 1975; Hester 1975c, 1977a, 1977b; Nunley 1975, 1977). In 
conjunction with the project, Parker Nunley discovered and documented approximately 162 archaeological sites (most of which had prehistoric components and 69 of which were in Maverick County).

With assistance from the Department of Housing and Urban Development, EHA prepared An Assessment of the Known Cultural Resources of the Middle-Rio Grande Area Prior to European Contact for the Middle-Rio Grande Development Council of Del Rio, Texas, in 1979. The report contains a compendium of recorded archaeological sites, cultural chronologies and trait lists, and cites 301 references pertinent to the history and archaeology of the nine-county area studied. In 1980, EHA also conducted a cultural resource inventory and assessment (intensive survey) for a 37.64 ha (93 a) area owned by the Central Power and Light Company in Eagle Pass. The property was located on alluvial terraces within close proximity of the Rio Grande channel. During that survey, six single-component prehistoric archaeological sites and one multi-component site (with both Prehistoric and Historic period affiliations) were discovered and recorded. Also in the early 1980s, EHA investigated 1,232.03 ha (3,044.31 a, approximately 1,629 a of which were within the Dos Republicas permit area as redefined for the 1992 CAR study) near Eagle Pass for Dahlstrom Corporation (Espey, Huston \& Associates 1981).

CAR investigations were conducted in the Eagle Pass vicinity in 1977, 1979, and 1990. The 1977 work was at the Seco Mines northwest of Eagle Pass and involved test excavations at 41MV57, a prehistoric Indian site on a tributary of Seco Creek (Frkuska et al. 1977). Two projects were undertaken in 1979: (1) an archaeological investigation of portions of the upper terrace alluvium of the Rio Grande (Fox and Whitsett 1979), and (2) a pedestrian archeological survey of approximately 100 ha (about 250 a) of land on which the new Eagle Pass Municipal Airport was built (Brown 1979). The former discovered and recorded one prehistoric Indian site (41MV65); the latter documented three prehistoric Indian sites (41MV71, 41MV192, and 41MV173). In 1990, CAR sent a field archaeological team to the site of the proposed International Bridge II to discover and evaluate cultural resources within the construction impact area for the bridge and associated improvements (Potter 1990).

Two other cultural resource investigations were undertaken in the Eagle Pass area during the early 1990s. In 1990, Rick Hubbard and Daniel Fox, archaeologists with the Texas Water Development Board, conducted a survey of the site of proposed improvements to the Eagle Pass wastewater treatment system. They discovered and recorded nine archaeological sites that exhibited potential for National Register of Historic Places designation. In July 1991, Mariah Associates of Austin, Texas, surveyed two pipeline routes and recorded and test excavated two previously unknown archaeological sites. One of the sites tested (41MV106) contained a basin-shaped hearth that was relatively well preserved. Flotation samples from the hearth yielded a variety of plant species remains including those of acacia or mesquite, prickly pear, spikerush, bulrush, spiderflower or beeweed, purslane, goosefoot, sunflowers, and the spines of several additional varieties of cacti. Charcoal from the hearth radiocarbon dated to the A.D. 300-400 period (Lintz 1992:9-10). 


\section{ARCHAEOLOGICAL SITES AND ARTIFACTS}

\section{INTRODUCTION}

Summary data on the 54 archaeological sites found within the Dos Republicas Project permit area by CAR in 1992 and by EHA in 1981 are presented in Table 2. Locations of the 27 sites discovered by CAR are shown in Figure 2 and locations of the EHA sites are shown in Figure 3 . Of 33 sites (41MV139, 41MV158-161, 41MV167, and 41MV174-200) examined by CAR during the Phase II investigations, two were not able to be cleared of further requirements until additional information is obtained and reviewed by the THC-DAP and the RCT. Eleven more warranted the performance of future work either in the form of initial shovel testing, additional shovel testing, or intensive subsurface testing to determine (1) extent and content of cultural deposits, (2) eligibility for designation as a state archaeological landmark and/or (3) eligibility for listing in the National Register of Historic Places.

In addition to the aforementioned sites, 24 of the EHA sites warranted future work, initially in the form of relocation and shovel testing. The total amount of additional work to be performed on the latter will depend upon the results of the initial shovel tests, the recommendations of the archaeological contractor performing the tests, and of the THC-DAP and the RCT. Thus, further archaeological work is recommended herein on a total of 37 sites. All of the sites not recommended for future investigations either: (1) exhibited poorly preserved, small-scale, or low-density surface features; (2) were in areas known to have been radically disturbed by soil conservation, brush control, agricultural or ranching activities; and/or (3) produced virtually no cultural material from subsurface tests.

Selected artifacts collected from the CAR Phase II sites are shown in Figures 4-11. Explanations of chipped stone artifact terminology and typology appear in Crabtree (1982), Davis (1991), Peck (1991), Suhm and Jelks (1962), and Turner and Hester (1985).

The following pertains only to the 33 sites examined by CAR during the 1992 Phase II Dos Republicas archaeological investigations. With the exception of one prehistoric site (41MV186) that contained two Late Paleo-Indian projectile point fragments that may have been brought to the site or used by indigenous peoples during post-Paleo-Indian times (cf. Hester 1968:159; Montgomery 1978:18), and of one historic site (41MV199), the sites are affiliated with the prehistoric era, Archaic and/or Late Prehistoric periods. Those affiliations are based largely on surface finds of time-diagnostic artifacts at the sites. In assigning small, light-weight projectile points (which bordered morphologically between dart and arrowpoints) to a particular cultural affiliation, for purposes of classification and analysis they were usually assumed to be dart points (cf. Hester 1974b:21 regarding the Figueroa and Zavala types). Shovel and backhoe subsurface tests yielded virtually no time-diagnostic artifacts and revealed few well-preserved or primary cultural strata, the best exception being at $41 \mathrm{MV} 160$. At that site, a nearly contiguous (throughout the test trench) horizontal layer of fragmented and burned quartzite cobbles mixed with chert chipping debris and ash-stained soil was unearthed at a depth of about $47 \mathrm{~cm}$ below the surface.

The prehistoric sites consisted of surface or very-near-surface scatters of cultural debris that included hammerstones and cores; preforms, projectile points, specialized tools, and other time-diagnostic artifacts; numerous flakes, chips, and burned rocks; a few freshwater mussel shell and land snail shell fragments; and rarely, charcoal and bone fragments (cf. Hester and Hill 1975:7; Montgomery 1978:137). A single piece of burned animal bone that was probably of prehistoric cultural origins was found at 41MV187. Also, a few of the prehistoric sites yielded incised stone or mano or metate fragments (Figure 8). Again, nearly the entire surface of the mining permit area was littered with cultural material of Indian origins, 
TABLE 2. SUMMARY DATA AND RECOMMENDATIONS FOR DOS REPUBLICAS PROJECT ARCHAEOLOGICAL SITES.

\begin{tabular}{|c|c|c|c|c|c|c|c|}
\hline Number & Type & $\begin{array}{l}\text { Location/ } \\
\text { Elevation }\end{array}$ & $\begin{array}{c}\text { Diagnostic } \\
\text { Artifacts/ } \\
\text { Features }\end{array}$ & $\begin{array}{c}\text { Cultural } \\
\text { Affiliations }\end{array}$ & $\begin{array}{l}\text { Five-Year } \\
\text { Permit } \\
\text { Boundary }\end{array}$ & $\begin{array}{l}\text { Proposed } \\
\text { Impact }\end{array}$ & Recommendations \\
\hline $41 M V 131$ & Open Camp & $\begin{array}{c}\text { Elm Creek Floodplain/ } \\
236 \mathrm{~m} \text { asl }\end{array}$ & None & Not Determined & Outside & Unknown & Relocation and Assessment \\
\hline $41 M V 132$ & Open Camp & $\begin{array}{l}\text { Elm Creek Floodplain' } \\
236 \mathrm{~m} \text { asl }\end{array}$ & $\begin{array}{l}\text { None/Possible Surface } \\
\text { Hearth Remnant }\end{array}$ & Not Determined & Inside & $\begin{array}{l}\text { Haul Road and } \\
\text { Diversion }\end{array}$ & Relocation and Assessment \\
\hline *41MV135 & Open Camp & $\begin{array}{l}\text { Hilly Uplands (terrace of } \\
\text { unnamed tributary of Elm } \\
\text { Creek) } / 239 \mathrm{~m} \text { asl }\end{array}$ & None & Not Delermined & Inside & Sediment Pond & Relocation and Assessment \\
\hline $41 \mathrm{MV} 136$ & Open Camp & $\begin{array}{l}\text { Hilly Uplands (terrace of } \\
\text { unnamed tributary of Elm } \\
\text { Creek) } / 238 \mathrm{~m} \text { asl }\end{array}$ & $\begin{array}{l}\text { None/Intact Surface Hearth } \\
\text { Remnants }\end{array}$ & Not Determined & Inside & Surface Mining & Relocation and Assessment \\
\hline $41 \mathrm{MV} 137$ & Open Camp & $\begin{array}{l}\text { Hilly Uplands (terrace of } \\
\text { unnamed tributary of Elm }\end{array}$ & None & Not Determined & Inside & Topsoil Stockpile & Relocation and Assessment \\
\hline & & Creck)/244 m asl & & & & & \\
\hline *41MV138 & Open Camp & $\begin{array}{l}\text { Hilly Uplands (terrace of } \\
\text { unnamed tributary of Elm } \\
\text { Creek) } / 244 \mathrm{~m} \text { asl }\end{array}$ & None & Not Determined & Inside & Surface Mining & Relocation and Assessment \\
\hline $41 \mathrm{MV} 139$ & Open Camp & $\begin{array}{l}\text { Hilly Uplands (terrace of } \\
\text { unnamed tributary of Elm } \\
\text { Creek) } / 250 \mathrm{~m} \text { asl }\end{array}$ & $\begin{array}{l}\text { None/Intact Subsurface } \\
\text { Hearth Remnants }\end{array}$ & Not Determined & Inside & Surface Mining & No Purther Work \\
\hline$\$ 1 M V 141$ & Unknown & $\begin{array}{l}\text { Hilly Uplands (terrace of } \\
\text { unnamed tributary of Elm } \\
\text { Creek) } / 250 \mathrm{~m} \text { asl }\end{array}$ & $\begin{array}{l}\text { D'hanis Brick } \\
\text { Concentrations and } \\
\text { Galvanized Metal } \\
\text { Wellhead }\end{array}$ & $\begin{array}{l}\text { Late 19th to Early } \\
\text { 20th Century Historic } \\
\text { Period }\end{array}$ & Inside & Haul Road & Relocation and Assessment \\
\hline $41 \mathrm{MV} 142$ & Open Camp & $\begin{array}{l}\text { Elm Creek Floodplain/ } \\
236 \mathrm{~m} \text { asl }\end{array}$ & None & Not Determined & Inside & Surface Mining & Relocation and Assessment \\
\hline $41 \mathrm{MV} 143$ & Open Camp & $\begin{array}{l}\text { Elm Creek Floodplain/ } \\
242 \mathrm{~m} \text { asl }\end{array}$ & None & Not Determined & Inside & Surface Mining & Relocation and Assessment \\
\hline *41MV144 & Open Camp & $\begin{array}{l}\text { Elm Creek Floodplain/ } \\
236 \mathrm{~m} \text { asl }\end{array}$ & None & Not Determined & Inside & $\begin{array}{l}\text { Haul Road and } \\
\text { Diversion }\end{array}$ & Relocation and Assessment \\
\hline $41 \mathrm{MV} 145$ & Open Camp & $\begin{array}{l}\text { Floodplain of Unnamed } \\
\text { Tributary of Elm Creek/ } \\
\qquad 233 \mathrm{~m} \text { asl }\end{array}$ & None & Not Determined & Inside & $\begin{array}{l}\text { Sediment Pond } \\
\text { P002 and } \\
\text { Diversion }\end{array}$ & Relocation and Assessment \\
\hline
\end{tabular}


TABLE 2. (continued)

\begin{tabular}{|c|c|c|c|c|c|c|c|}
\hline Number & Type & $\begin{array}{l}\text { Location/ } \\
\text { Elevation }\end{array}$ & $\begin{array}{c}\text { Diagnostic } \\
\text { Artifacts/ } \\
\text { Features }\end{array}$ & $\begin{array}{c}\text { Cultural } \\
\text { Affiliations }\end{array}$ & $\begin{array}{l}\text { Five-Year } \\
\text { Permit } \\
\text { Boundary }\end{array}$ & $\begin{array}{l}\text { Proposed } \\
\text { Impact }\end{array}$ & Recommendations \\
\hline *41MV146 & Open Camp & $\begin{array}{l}\text { Elm Creek Floodplain/ } \\
235 \mathrm{~m} \text { asl }\end{array}$ & None & Not Determined & Inside & Haul Road & Relocation and Assessment \\
\hline *41MV155 & Open Camp & $\begin{array}{l}\text { Hilly Uplands (terrace of } \\
\text { unnamed tributary of Elm } \\
\text { Creek) } / 250 \mathrm{~m} \text { asl }\end{array}$ & None & Not Determined & Inside & $\begin{array}{l}\text { Sediment Pond } \\
\text { P009 }\end{array}$ & Relocation and Assessment \\
\hline$-41 \mathrm{MV} 157$ & Open Camp & $\begin{array}{l}\text { Hilly Uplands (terrace of } \\
\text { unnamed tributary of Elm } \\
\text { Creek) } / 240 \mathrm{~m} \text { asl }\end{array}$ & $\begin{array}{c}\text { None/Intact Surface Hearth } \\
\text { Remnants }\end{array}$ & Not Determined & Inside & $\begin{array}{c}\text { Minimal } \\
\text { Disturbance }\end{array}$ & Relocation and Assessment \\
\hline $41 \mathrm{MV} 158$ & Open Camp & $\begin{array}{l}\text { Hilly Uplands (terrace of } \\
\text { unnamed tributary of Elm } \\
\text { Creek) } / 242 \mathrm{~m} \text { asl }\end{array}$ & $\begin{array}{l}\text { Guadalupe Tool, } \\
\text { Unidentified Dart } \\
\text { Point/Possible Intact } \\
\text { Bumed Rock Features }\end{array}$ & $\begin{array}{l}\text { Prehistoric Archaic } \\
\text { Period }\end{array}$ & Inside & Surface Mining & No Further Work \\
\hline $41 \mathrm{MV} 159$ & Open Camp & $\begin{array}{l}\text { Hilly Uplands (terrace of } \\
\text { unnamed tributary of Elm } \\
\text { Creek) } / 244 \mathrm{~m} \text { asl }\end{array}$ & $\begin{array}{c}\text { Marshall-like Dart } \\
\text { Point/Intact Surface Hearth } \\
\text { Remnants }\end{array}$ & $\begin{array}{l}\text { Prehistoric Archaic } \\
\text { Period }\end{array}$ & Inside & $\begin{array}{c}\text { Minimal } \\
\text { Disturbance }\end{array}$ & No Further Work \\
\hline $41 \mathrm{MV} 160$ & Open Camp & $\begin{array}{l}\text { Hilly Uplands (terrace of } \\
\text { unnamed tributary of Elm } \\
\text { Creek)/244 m asl }\end{array}$ & $\begin{array}{l}\text { Ensor and Frio Dart } \\
\text { Points/lntact Subsurface } \\
\text { Burned Rock Features }\end{array}$ & $\begin{array}{l}\text { Prehistoric Archaic } \\
\text { Period }\end{array}$ & Inside & Surface Mining & $\begin{array}{l}\text { Extensive Controlled Surface } \\
\text { Survey and Intensive } \\
\text { Subsurface Testing }\end{array}$ \\
\hline 41MV161 & Open Camp & $\begin{array}{l}\text { Hilly Uplands (terrace of } \\
\text { unnamed tributary of Elm } \\
\text { Creek) } / 246 \mathrm{~m} \text { asl }\end{array}$ & $\begin{array}{l}\text { Almagre Large Stemmed } \\
\text { Point/lntact Surface Hearth } \\
\text { Remnants }\end{array}$ & $\begin{array}{l}\text { Prehistoric Archaic } \\
\text { Period }\end{array}$ & Inside & Surface Mining & $\begin{array}{l}\text { Extensive Controlled Surface } \\
\text { Survey and Intensive } \\
\text { Subsurface Testing }\end{array}$ \\
\hline $41 \mathrm{MV} 164$ & Open Camp & $\begin{array}{l}\text { Floodplain of Unnamed } \\
\text { Tributary of Elm Creek } \\
\qquad 237 \mathrm{~m} \text { asl }\end{array}$ & $\begin{array}{l}\text { Ensor-like and Frio Dart } \\
\text { Point Fragments, Clear } \\
\text { Fork Tool, Metate }\end{array}$ & $\begin{array}{c}\text { Prehistoric Archaic } \\
\text { Period }\end{array}$ & Inside & $\begin{array}{l}\text { Haul Road and } \\
\text { Facilities }\end{array}$ & Relocation and Assessment \\
\hline $41 \mathrm{MV} 165$ & Open Camp & $\begin{array}{l}\text { Floodplain of Unnamed } \\
\text { Tributary of Elm Creek/ } \\
237 \mathrm{~m} \text { asl }\end{array}$ & $\begin{array}{c}\text { None/Possible Intact } \\
\text { Surface Hearth Remnants }\end{array}$ & Not Determined & Inside & Topsoil Stockpile & Relocation and Assessment \\
\hline $41 \mathrm{MV} 166$ & Open Camp & $\begin{array}{l}\text { Floodplain of Unnamed } \\
\text { Tribulary of Elm Creek/ } \\
\qquad 237 \mathrm{~m} \text { asl }\end{array}$ & $\begin{array}{l}\text { Marcos Dart Point } \\
\text { Fragment }\end{array}$ & $\begin{array}{l}\text { Prehistoric Archaic } \\
\text { Period }\end{array}$ & Inside & Surface Mining & Relocation and Assessment \\
\hline
\end{tabular}


TABLE 2. (continued)

\begin{tabular}{|c|c|c|c|c|c|c|c|}
\hline Number & Type & $\begin{array}{l}\text { Location/ } \\
\text { Elevation }\end{array}$ & $\begin{array}{l}\text { Diagnostic } \\
\text { Artifacts/ } \\
\text { Features }\end{array}$ & $\begin{array}{c}\text { Cultural } \\
\text { Affiliations }\end{array}$ & $\begin{array}{l}\text { Five-Year } \\
\text { Permit } \\
\text { Boundary }\end{array}$ & $\begin{array}{l}\text { Proposed } \\
\text { Impact }\end{array}$ & Recommendations \\
\hline $41 \mathrm{MV} 167$ & Open Camp & $\begin{array}{l}\text { Elm Creek Floodplain/ } \\
\qquad 242 \mathrm{~m} \text { asl }\end{array}$ & $\begin{array}{l}\text { Frio, Langtry-like, and } \\
\text { Unidentified Dart Point } \\
\text { Fragments/Possible Intact } \\
\text { Surface Hearth Remnant }\end{array}$ & $\begin{array}{l}\text { Prehistoric Archaic } \\
\text { Period }\end{array}$ & Inside & Surface Mining & No Further Work \\
\hline $41 \mathrm{MV} 168$ & Open Camp & $\begin{array}{l}\text { Hilly Uplands near Transition } \\
\text { with Elm Creek Floodplain } \\
\text { Zone/248 m asl }\end{array}$ & None & Not Determined & Inside & Surface Mining & Relocation and Assessment \\
\hline *41MV170 & $\begin{array}{l}\text { Open Camp and } \\
\text { Lithic } \\
\text { Procurement }\end{array}$ & $\begin{array}{l}\text { Hilly Uplands (terrace of } \\
\text { unnamed tributary of Elm } \\
\text { Creek) } / 253 \mathrm{~m} \text { asl }\end{array}$ & None & Not Determined & Inside & Surface Mining & Relocation and Assessment \\
\hline${ }^{* 41 M V 171}$ & Open Camp & $\begin{array}{l}\text { Elm Creek Floodplain/ } \\
229 \mathrm{~m} \text { asl }\end{array}$ & None & Not Determined & Inside & Access Road & Relocation and Assessment \\
\hline $41 \mathrm{MV} 172$ & Open Camp & $\begin{array}{l}\text { Elm Creek Floodplain/ } \\
\qquad 230 \mathrm{~m} \text { asl }\end{array}$ & None & Not Determined & Inside & Surface Mining & Relocation and Assessment \\
\hline $411 \mathrm{MV} 173$ & $\begin{array}{l}\text { Isolated Artifact } \\
\text { Find }\end{array}$ & $\begin{array}{l}\text { Elm Creek Floodplain/ } \\
\qquad 235 \mathrm{~m} \text { asl }\end{array}$ & Lerma-like Dart Point & $\begin{array}{c}\text { Prehistoric Late } \\
\text { Paleoindian or Eariy } \\
\text { Archaic }\end{array}$ & Inside & $\begin{array}{l}\text { Access Road and } \\
\text { Ditch }\end{array}$ & Relocation and Assessment \\
\hline $41 \mathrm{MV} 174$ & Open Camp & $\begin{array}{l}\text { Elm Creek Floodplain/ } \\
\qquad 230 \mathrm{~m} \text { asl }\end{array}$ & None & Not Determined & Inside & $\begin{array}{l}\text { Sediment Pond } \\
\text { P016 }\end{array}$ & No Further Work \\
\hline $41 \mathrm{MV} 175$ & Open Camp & $\begin{array}{c}\text { Elm Creek Floodplain/ } \\
230 \mathrm{~m} \text { asl }\end{array}$ & None & Not Determined & Inside & Surface Mining & No Further Work \\
\hline $41 \mathrm{MV} 176$ & Open Camp & $\begin{array}{l}\text { Elm Creek Floodplain/ } \\
230 \mathrm{~m} \text { asl }\end{array}$ & None & Not Determined & Inside & Surface Mining & No Further Work \\
\hline $41 \mathrm{MV} 177$ & Open Camp & $\begin{array}{c}\text { Elm Creek Floodplain/ } \\
230 \mathrm{~m} \text { asl }\end{array}$ & Guadalupe Tool Fragment & $\begin{array}{l}\text { Prehistoric Archaic } \\
\text { Period }\end{array}$ & Inside & Surface Mining & No Further Work \\
\hline $41 \mathrm{MV} 178$ & Open Camp & $\begin{array}{l}\text { Eim Creek Floodplain/ } \\
230 \mathrm{~m} \text { asl }\end{array}$ & $\begin{array}{l}\text { Desmuke, Edgewood, and } \\
\text { Langtry Dart Points, Mano } \\
\text { Fragment }\end{array}$ & $\begin{array}{c}\text { Prehistoric Archaic } \\
\text { Period }\end{array}$ & Inside & Surface Mining & No Further Work \\
\hline $41 \mathrm{MV} 179$ & Open Camp & $\begin{array}{l}\text { Elm Creek Floodplain/ } \\
230 \mathrm{~m} \text { asl }\end{array}$ & None & Not Determined & Inside & $\begin{array}{l}\text { Sediment Pond } \\
\text { P014 }\end{array}$ & No Further work \\
\hline
\end{tabular}


TABLE 2. (continued)

\begin{tabular}{|c|c|c|c|c|c|c|c|}
\hline Number & Type & $\begin{array}{l}\text { Location/ } \\
\text { Elevation }\end{array}$ & $\begin{array}{l}\text { Diagnostic } \\
\text { Artifacts/ } \\
\text { Features }\end{array}$ & $\begin{array}{c}\text { Cultural } \\
\text { Affiliations }\end{array}$ & $\begin{array}{l}\text { Five-Year } \\
\text { Permit } \\
\text { Boundary }\end{array}$ & $\begin{array}{l}\text { Proposed } \\
\text { Impact }\end{array}$ & Recommendations \\
\hline $41 \mathrm{MV} 180$ & Open Camp & $\begin{array}{l}\text { Elm Creek Floodphin } \\
230 \mathrm{~m} \text { asl }\end{array}$ & $\begin{array}{l}\text { Edgewood and Frio Dart } \\
\text { Poinls }\end{array}$ & $\begin{array}{l}\text { Prehistoric Archaic } \\
\text { Period }\end{array}$ & Inside & None & No Further Work \\
\hline 41MV181 & Open Camp & $\begin{array}{l}\text { Upland Terrace of Elm } \\
\text { Creek/ } / 250 \mathrm{~m} \text { asl }\end{array}$ & $\begin{array}{l}\text { Abasolo, Figueroa, and } \\
\text { Palmillas Dart Points; } \\
\text { Zavala Arrowpoint }\end{array}$ & $\begin{array}{c}\text { Prehistoric Archaic } \\
\text { and Late Prehistoric } \\
\text { Periods }\end{array}$ & Inside & None & No Further Work \\
\hline $41 M V 182$ & Open Camp & $\begin{array}{l}\text { Elm Creek Floodplain/ } \\
230 \mathrm{~m} \text { asl }\end{array}$ & $\begin{array}{l}\text { Abasolo, Ensor, Figueroa, } \\
\text { Martindale, and Pandale } \\
\text { Dart Points; Zavala } \\
\text { Arrowpoint; Engraved } \\
\text { Stone; Mano Fragments }\end{array}$ & $\begin{array}{c}\text { Prehistoric Archaic } \\
\text { and Late Prehistoric } \\
\text { Periods }\end{array}$ & Inside & Access Road & $\begin{array}{l}\text { Pending Further } \\
\text { Interpretstion by THC-DAP } \\
\text { of Phase II Work }\end{array}$ \\
\hline $41 \mathrm{MV} 183$ & Open Camp & $\begin{array}{l}\text { Elm Creck Floodplain/ } \\
230 \mathrm{~m} \text { asl }\end{array}$ & $\begin{array}{l}\text { Unidentified Projectile } \\
\text { Point }\end{array}$ & Not Detemined & Inside & Surface Mining & $\begin{array}{l}\text { Pending Further } \\
\text { Interpretation by THC-DAP } \\
\text { of Phase II Work }\end{array}$ \\
\hline $41 \mathrm{MV} 184$ & Open Camp & $\begin{array}{l}\text { Elm Creek Floodplain/ } \\
230 \mathrm{~m} \text { asl }\end{array}$ & None & Not Determined & Inside & Surface Mining & $\begin{array}{l}\text { Additional Shovel Testing } \\
\text { and Subsequent } \\
\text { Recommendations of the } \\
\text { THC-DAP }\end{array}$ \\
\hline $41 M V 185$ & Open Camp & $\begin{array}{l}\text { Elm Creek Floodplain/ } \\
230 \mathrm{~m} \text { asl }\end{array}$ & $\begin{array}{l}\text { Castroville, Conejo, } \\
\text { Edgewood, Marshall, } \\
\text { Matamoros, and Pandale } \\
\text { Dart Points; Arrowpoint } \\
\text { Preform/High Density } \\
\text { Cultural Debris Scatters }\end{array}$ & $\begin{array}{c}\text { Prehistoric Archaic } \\
\text { and Late Prehistoric } \\
\text { Periods }\end{array}$ & Inside & Surface Mining & $\begin{array}{l}\text { Extensive Controlled Surface } \\
\text { Survey and Intensive } \\
\text { Subsurface Testing }\end{array}$ \\
\hline 41MV186 & Open Camp & $\begin{array}{l}\text { Elm Creck Floodplain/ } \\
230 \mathrm{~m} \text { asl }\end{array}$ & $\begin{array}{l}\text { Angostura, Langtry, and } \\
\text { Paisano Dart Points; Dart } \\
\text { and Arrowpoint } \\
\text { Preforms/Intact Surface } \\
\text { Hearth Remnants and High } \\
\text { Density Cultural Debris } \\
\text { Scatters }\end{array}$ & $\begin{array}{c}\text { Prehistoric } \\
\text { Paleoinidan, Archaic } \\
\text { and Late Prehistoric } \\
\text { Periods }\end{array}$ & Inside & Surface Mining & $\begin{array}{l}\text { Extensive Controlled Surface } \\
\text { Survey and Intensive } \\
\text { Subsurface Testing }\end{array}$ \\
\hline $41 \mathrm{MV} 187$ & Open Camp & $\begin{array}{l}\text { Elm Creek Floodplain/ } \\
230 \mathrm{~m} \text { asl }\end{array}$ & $\begin{array}{l}\text { Fairland and Figueroa Dart } \\
\text { Points; Perdiz Arrow- } \\
\text { poin//Intact Surface Hearth } \\
\text { Remnants }\end{array}$ & $\begin{array}{c}\text { Prehistoric Archaic } \\
\text { and Late Prehistoric } \\
\text { Periods }\end{array}$ & Inside & Surface Mining & Intensive Subsurface Testing \\
\hline
\end{tabular}


TABLE 2. (continued)

\begin{tabular}{|c|c|c|c|c|c|c|c|}
\hline Number & Type & $\begin{array}{l}\text { Location/ } \\
\text { Elevation }\end{array}$ & $\begin{array}{l}\text { Diagnostic } \\
\text { Artifacts/ } \\
\text { Features }\end{array}$ & $\begin{array}{c}\text { Cultural } \\
\text { Affiliations }\end{array}$ & $\begin{array}{l}\text { Five-Year } \\
\text { Permit } \\
\text { Boundary }\end{array}$ & $\begin{array}{l}\text { Proposed } \\
\text { Impact }\end{array}$ & Recommendations \\
\hline $41 \mathrm{MV} 188$ & Open Camp & $\begin{array}{l}\text { Elm Creek Floodplain } / \\
230 \mathrm{~m} \text { asl }\end{array}$ & None & Not Determined & Inside & Surface Mining & $\begin{array}{l}\text { Additional Subsurface } \\
\text { Testing }\end{array}$ \\
\hline $41 \mathrm{MV} 189$ & Open Camp & $\begin{array}{l}\text { Elm Creek Floodplain/ } \\
230 \mathrm{~m} \text { asl }\end{array}$ & $\begin{array}{l}\text { Bell, Figueroa, Frio, } \\
\text { Langlry, Marcos, and } \\
\text { Pedemales Dart } \\
\text { Points/High Density } \\
\text { Cultural Debris Scatters }\end{array}$ & $\begin{array}{l}\text { Prehistoric Archaic } \\
\text { Period }\end{array}$ & Inside & Surface Mining & $\begin{array}{l}\text { Extensive Controlled Surface } \\
\text { Survey and Intensive } \\
\text { Subsurface Testing }\end{array}$ \\
\hline $41 \mathrm{MV} 190$ & Open Camp & $\begin{array}{l}\text { Elm Creek Floodplain/ } \\
230 \mathrm{~m} \text { asl }\end{array}$ & $\begin{array}{l}\text { Frio and Marcos Dart } \\
\text { Points }\end{array}$ & $\begin{array}{l}\text { Prehistoric Archaic } \\
\text { Period }\end{array}$ & Inside & Surface Mining & $\begin{array}{l}\text { Additional Shovel Testing } \\
\text { and Subsequent } \\
\text { Recommendations of the } \\
\text { THC-DAP }\end{array}$ \\
\hline $41 \mathrm{MV} 191$ & Open Camp & $\begin{array}{l}\text { Elm Creck Floodplain/ } \\
230 \mathrm{~m} \text { asl }\end{array}$ & $\begin{array}{l}\text { Arrowpoint Distal Tip and } \\
\text { Preform }\end{array}$ & Not Determined & Inside & Surface Mining & No Further Work \\
\hline $41 \mathrm{MV} 192$ & Open Camp & $\begin{array}{l}\text { Elm Creek Floodplain/ } \\
230 \mathrm{~m} \text { asl }\end{array}$ & $\begin{array}{l}\text { Perdiz, Scallom, and } \\
\text { Toyah-like Arrowpoints }\end{array}$ & $\begin{array}{l}\text { Late Prehistoric } \\
\text { Period }\end{array}$ & Inside & Surface Mining & No Further Work \\
\hline $41 \mathrm{MV} 193$ & Open Camp & $\begin{array}{l}\text { Elm Creck Floodplain/ } \\
230 \mathrm{~m} \text { asl }\end{array}$ & $\begin{array}{l}\text { Ensor, Figucros, and } \\
\text { Montell Dart Points; } \\
\text { Perdiz and Scallom } \\
\text { Arrowpoints/Extensive, } \\
\text { High Density Cultural } \\
\text { Debris Scatters }\end{array}$ & $\begin{array}{c}\text { Prehistoric Archaic } \\
\text { and Late Prehistoric } \\
\text { Periods }\end{array}$ & Inside & Surface Mining & $\begin{array}{l}\text { Pending Further } \\
\text { Interpretation by THC-DAP } \\
\text { of Phase II Work }\end{array}$ \\
\hline $41 \mathrm{MVI} 194$ & Open Camp & $\begin{array}{l}\text { Elm Creek Floodplain } / \\
230 \mathrm{~m} \text { asl }\end{array}$ & None & Not Determined & Ingide & Surface Mining & $\begin{array}{l}\text { Pending Further } \\
\text { Interpretation by THC-DAP } \\
\text { of Phase II Work }\end{array}$ \\
\hline 41MV195 & Open Camp & $\begin{array}{l}\text { Elm Creck Floodplain } / \\
230 \mathrm{~m} \text { asl }\end{array}$ & None & Not Determined & Inside & Surface Mining & $\begin{array}{l}\text { Additional Subsurface } \\
\text { Testing }\end{array}$ \\
\hline $41 \mathrm{MV} 196$ & Open Camp & $\begin{array}{l}\text { Elm Creek Floodplain/ } \\
230 \mathrm{~m} \text { asl }\end{array}$ & $\begin{array}{l}\text { Darl, Carrizo, and Pandora } \\
\text { Dart Points; Scaliom } \\
\text { Arrowpoint }\end{array}$ & $\begin{array}{c}\text { Prehistoric Archaic } \\
\text { and Late Prehistoric } \\
\text { Periods }\end{array}$ & Inside & Surface Mining & No Further Work \\
\hline 41MV197 & Open Camp & $\begin{array}{l}\text { Elm Creek Floodplain/ } \\
\qquad 230 \mathrm{~m} \text { asl }\end{array}$ & Pandale Dart Point & $\begin{array}{l}\text { Prehistoric Archaic } \\
\text { Period }\end{array}$ & Inside & Surface Mining & No Further Work \\
\hline
\end{tabular}


TABLE 2. (continued)

\begin{tabular}{|c|c|c|c|c|c|c|c|}
\hline Number & Type & $\begin{array}{l}\text { Location/ } \\
\text { Elevation }\end{array}$ & $\begin{array}{c}\text { Diagnostic } \\
\text { Artifacts/ } \\
\text { Features }\end{array}$ & $\begin{array}{c}\text { Cultural } \\
\text { Affiliations }\end{array}$ & $\begin{array}{l}\text { Five-Year } \\
\text { Permit } \\
\text { Boundary }\end{array}$ & $\begin{array}{l}\text { Proposed } \\
\text { Impact }\end{array}$ & Recommendations \\
\hline $41 \mathrm{MV} 198$ & Open Camp & $\begin{array}{l}\text { Elm Creek Floodplain/ } \\
230 \mathrm{~m} \text { asl }\end{array}$ & $\begin{array}{c}\text { Almagre Large-stemmed } \\
\text { Point }\end{array}$ & $\begin{array}{l}\text { Prehistoric Archaic } \\
\text { Period }\end{array}$ & Inside & Surface Mining & No Further Work \\
\hline $41 \mathrm{MV} 199$ & $\begin{array}{l}\text { Railroad or } \\
\text { Ranch Work } \\
\text { Camp }\end{array}$ & $\begin{array}{l}\text { Elm Creek Floodplain } / \\
230 \mathrm{~m} \text { asl }\end{array}$ & $\begin{array}{l}\text { Transferware, Banded } \\
\text { Slip, Lead Glaze, } \\
\text { Stoneware, Ironstone } \\
\text { Ceramic Fragments; Milk } \\
\text { Glass and Botlle Glass } \\
\text { Fragments; Square Spikes } \\
\text { and Nails; Miscellaneous } \\
\text { Metal Fragments } \\
\text { (houschold and } \\
\text { construction); Animal } \\
\text { Bone Fragments/Stone } \\
\text { Foundation Remnants }\end{array}$ & $\begin{array}{l}\text { 19th and 20th Century } \\
\text { Historic Period }\end{array}$ & Inside & Topsoil Stockpile & $\begin{array}{l}\text { Archival and Oral History } \\
\text { Research; Mapping; and } \\
\text { Intensive Subsurface Testing }\end{array}$ \\
\hline $41 \mathrm{MV} 200$ & Open Camp & $\begin{array}{l}\text { Elm Creek Floodplain/ } \\
230 \mathrm{~m} \text { asl }\end{array}$ & $\begin{array}{c}\text { Castroville and Edgewood } \\
\text { Dart Points; Perdiz Arrow- } \\
\text { point }\end{array}$ & $\begin{array}{c}\text { Prehistoric Archaic } \\
\text { and Late Prehistoric } \\
\text { Periods }\end{array}$ & Inside & None & No Further Work \\
\hline
\end{tabular}

* Sites not examined during the 1992 CAR Phase II survey. Data shown were extracted from 1981 vintage EH\&A archaeological site forms on file at the TARL-UT.

Note: Data shown in the following columns were provided courtesy of Marston \& Marston, Inc., St. Louis, Missouri: (1) Five-Year Permit Boundary; (2) Proposed Impact. Recommendations are based on the findings of CAR and on commentary and review by the THC-DAP and the RCT made after the first manuscript draft was submitted. 


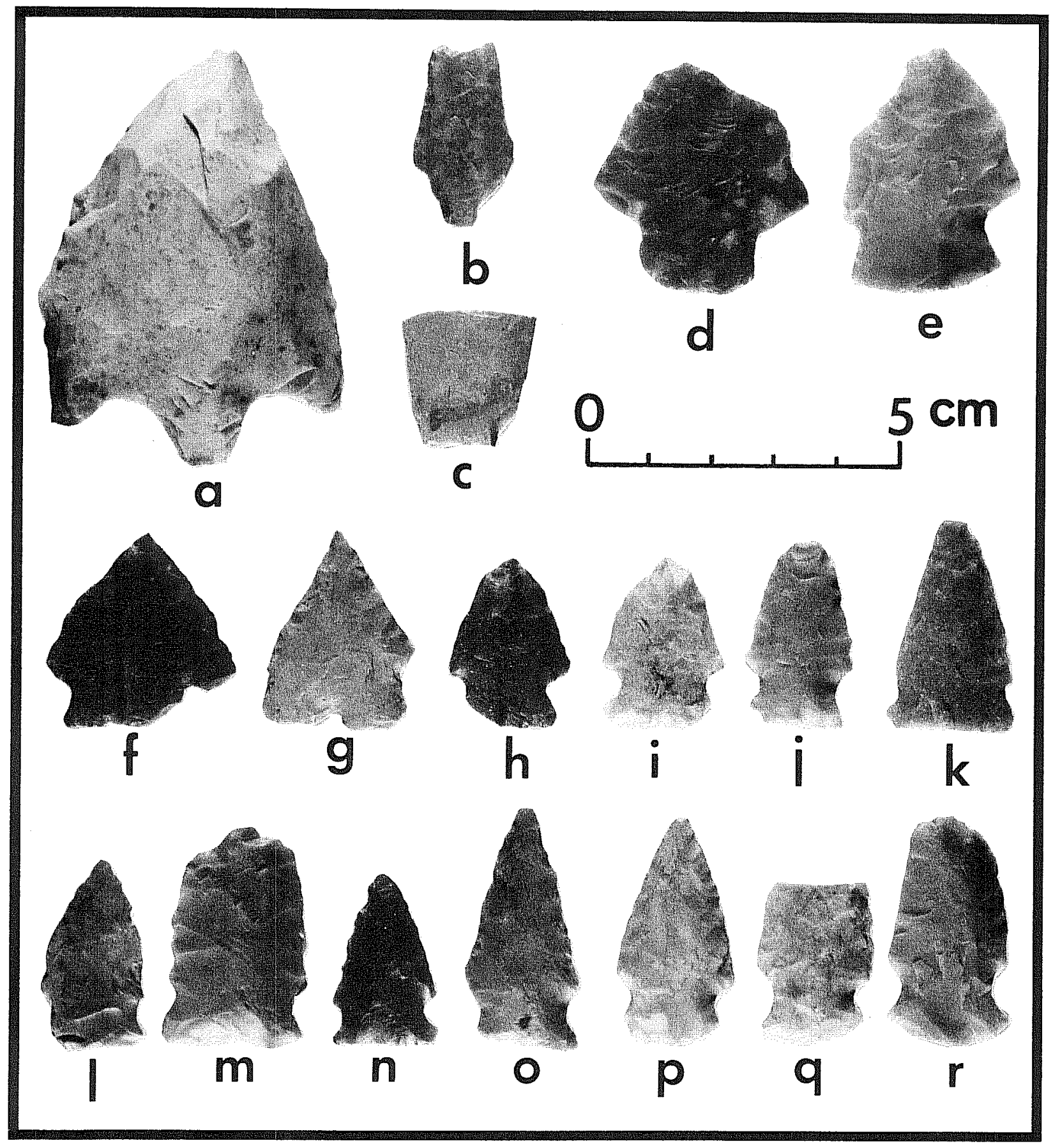

Figure 4. Diagnostic Surface Artifacts from the Phase II Dos Republicas Project Archaeological Survey. All are dart points or dart point fragments. a, Almagre (or Langtry preform); b, c, Angostura; d, Bell; e, Castroville; f, g, Conejo; h, i, Edgewood; j-n, Ensor; o, Fairland; p-r, Figueroa (or possibly Zavala arrowpoints). 


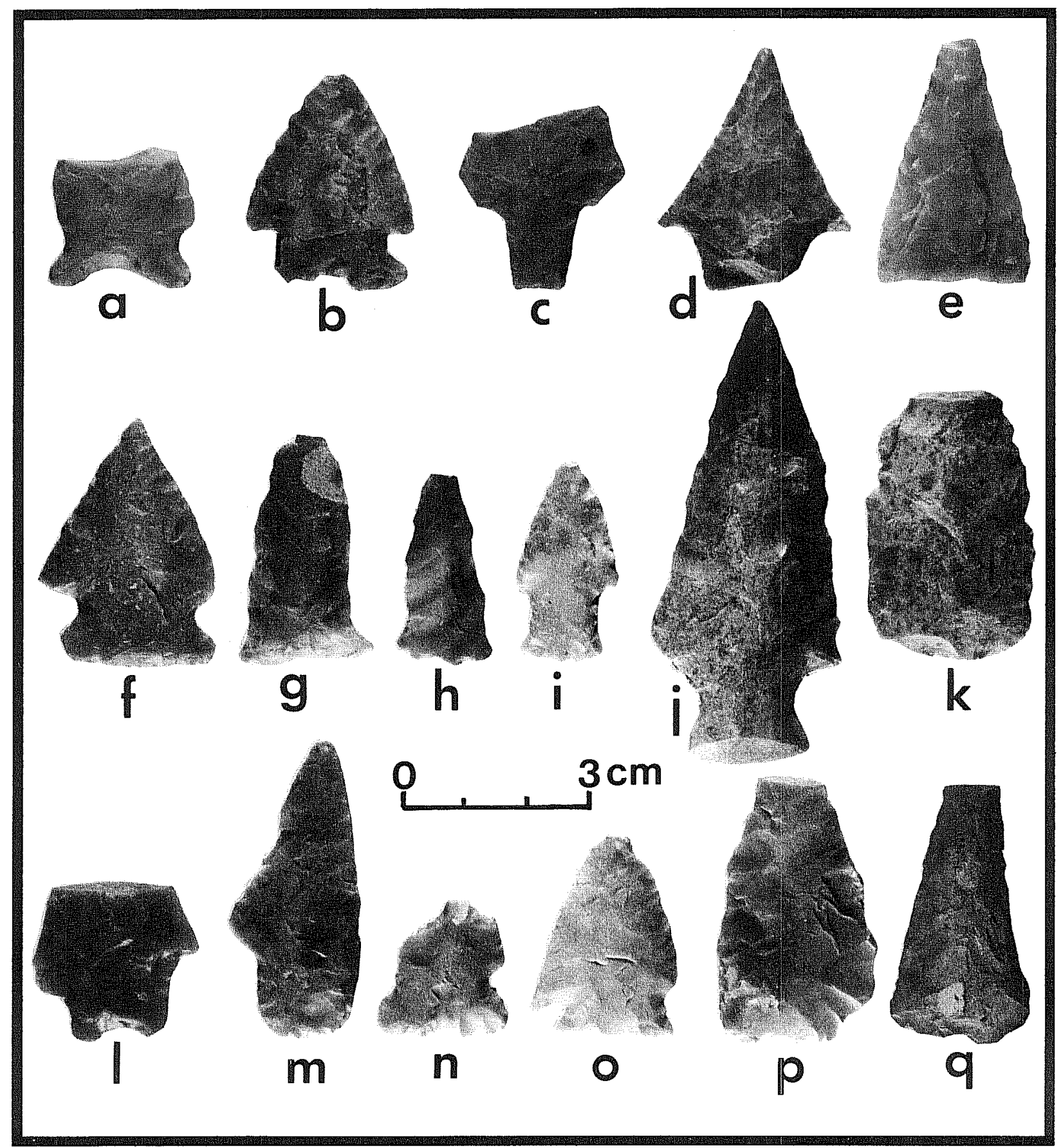

Figure 5. Diagnostic Surface Artifacts from the Phase II Dos Republicas Project Archaeological Survey. All except $q$ are dart points or dart point fragments. a, b, Frio; c, d, Langtry; e, Matamoros; f, Marcos; g, h, Paisano; i, j, Palmillas; $k$, Pandora; $m-p$, unidentified; $q$, perforator. 


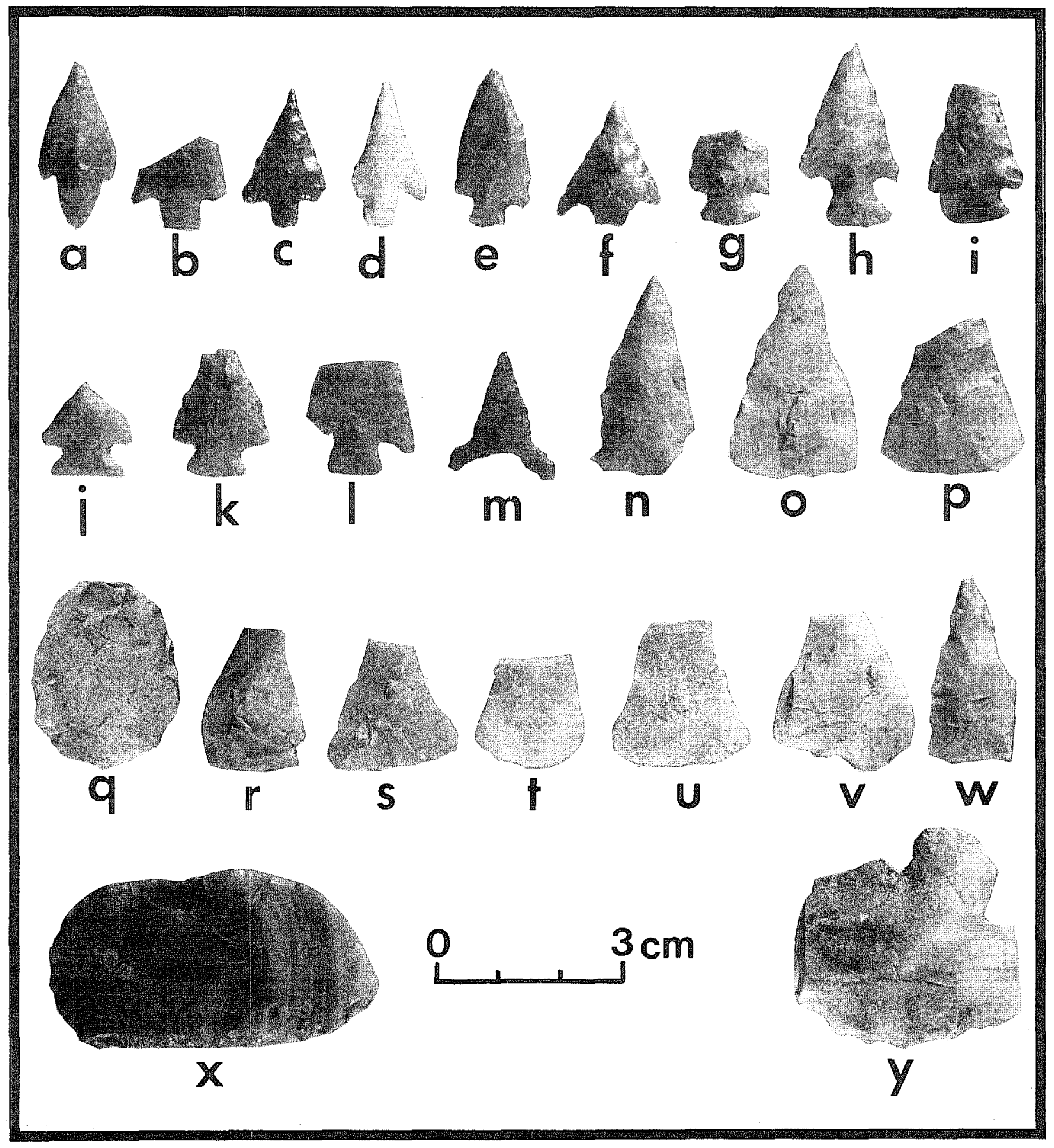

Figure 6. Surface Artifacts from the Phase II Dos Republicas Project Archaeological Survey. a-n, are arrowpoints, $0-\mathrm{w}$, arrowpoint preforms; $\mathrm{x}$, is a unifacial flake scraping tool; $\mathrm{y}$, a corner tang tool fragment. a, b, Perdiz; c-f, unidentified; g-l, Scallorn; m, Toyah-like; n, Zavala. 


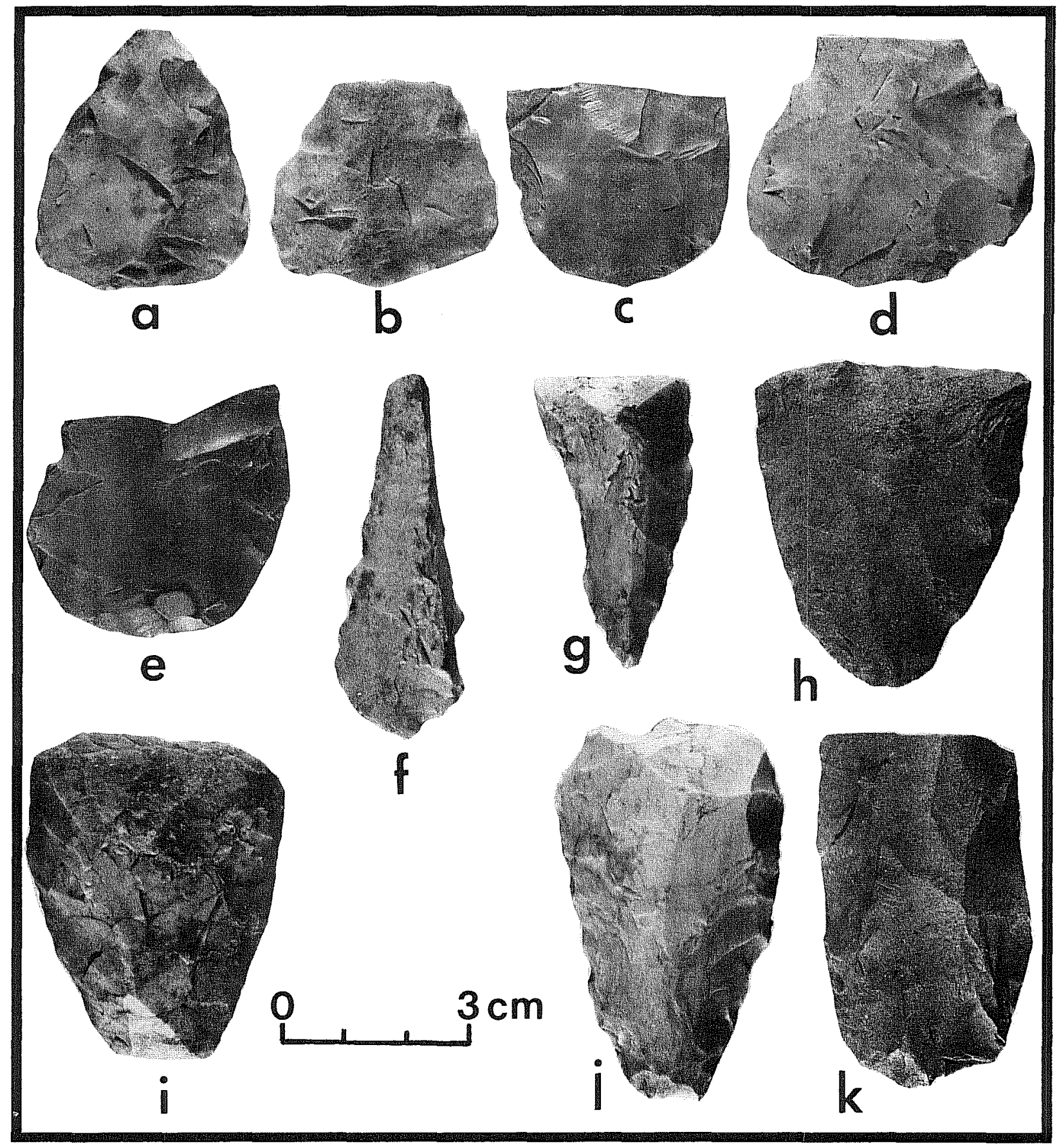

Figure 7. Surface Artifacts from the Phase II Dos Republicas Project Archaeological Survey. a-e, large preforms; f, perforator; g, unidentified tool; h, bifacial Clear Fork took; i, unifacial Clear Fork tool; j, $\mathrm{k}$, Guadalupe tool fragments. 


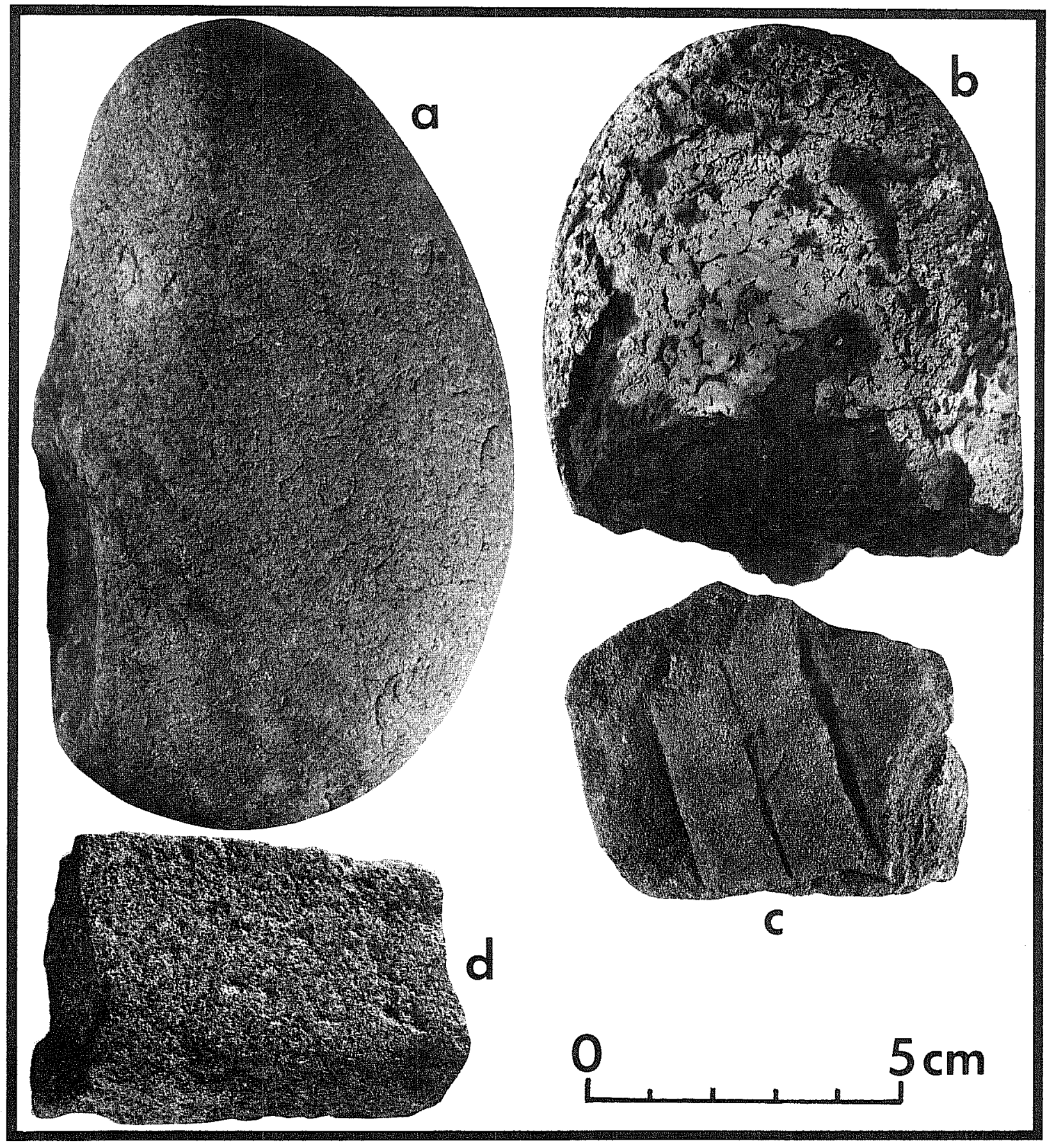

Figure 8. Surface Artifacts from the Phase II Dos Republicas Project Archaeological Survey. a, quartzite mano; $b$, andesite mano fragment; c, grooved sandstone fragment; $d$, basalt-porphyry mano fragment. 


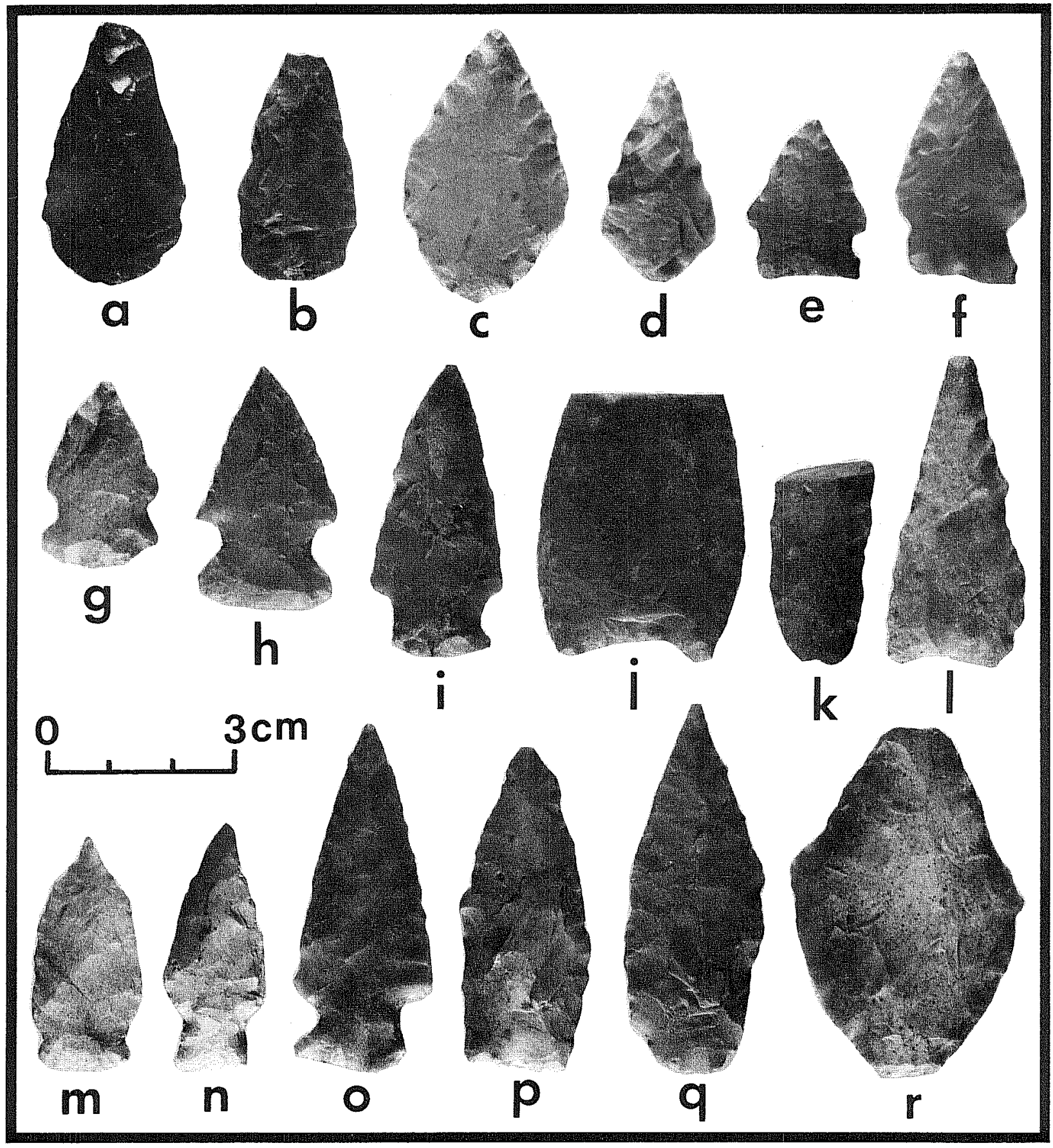

Figure 9. Diagnostic Surface Artifacts from the Phase II Dos Republicas Project Archaeological Survey. All except $\mathbf{r}$ (a reworked beveled biface) are dart points or dart point fragments. a, b, Catan; c, d, Desmuke; d, Edgewood; f, Fairland; g-i, Figueroa; j, Kinney; k, Lerma, 1, Paisano; m-o, Palmillas; p, Pandale; q, Refugio. 


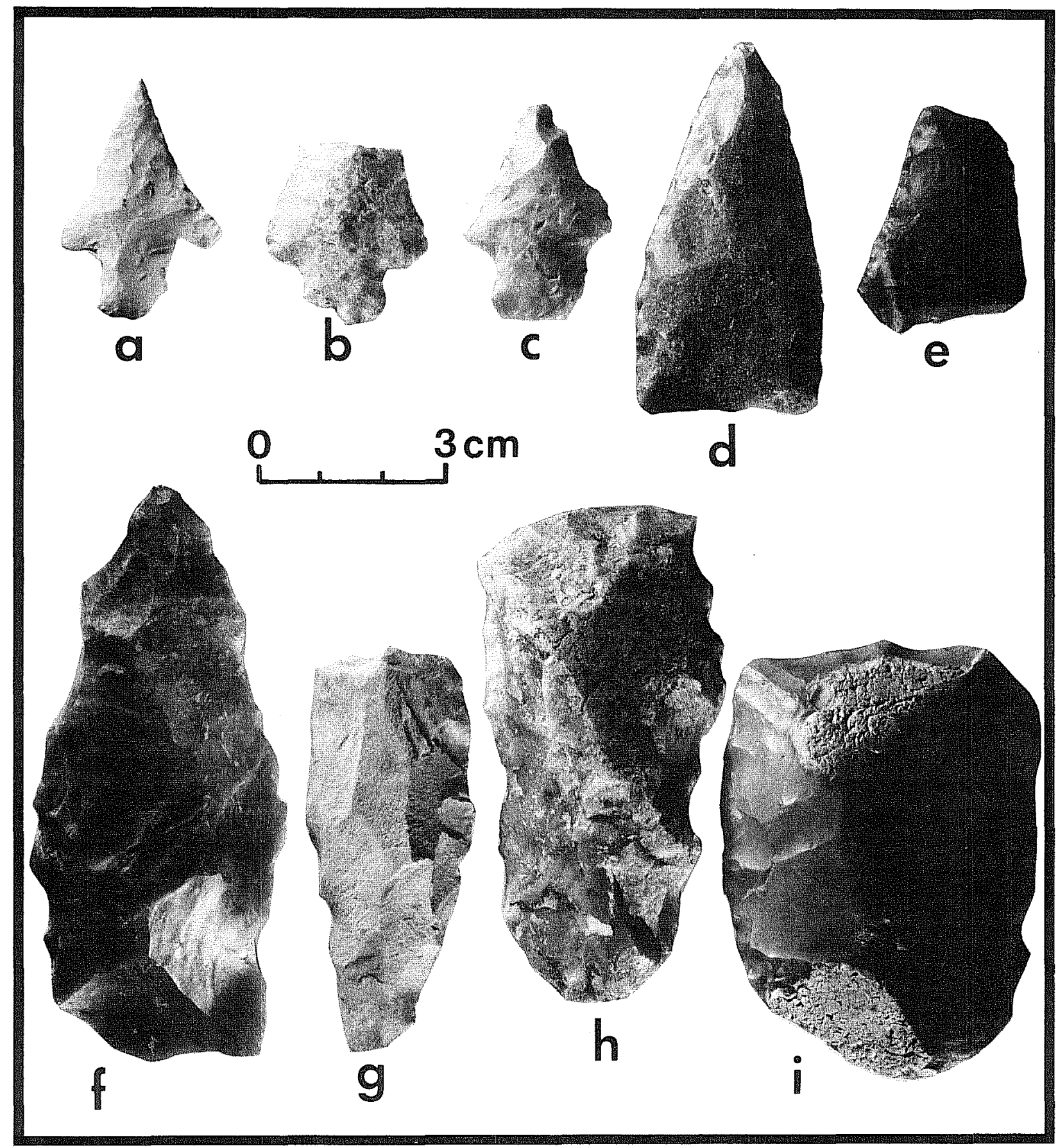

Figure 10. Surface Artifacts from the Phase II Dos Republicas Project Archaeological Survey. a, b, Shumla dart points; c-e, unidentified dart points; $f, g$, unidentified thick bifaces; $h$, i, unidentified thick unifaces. 


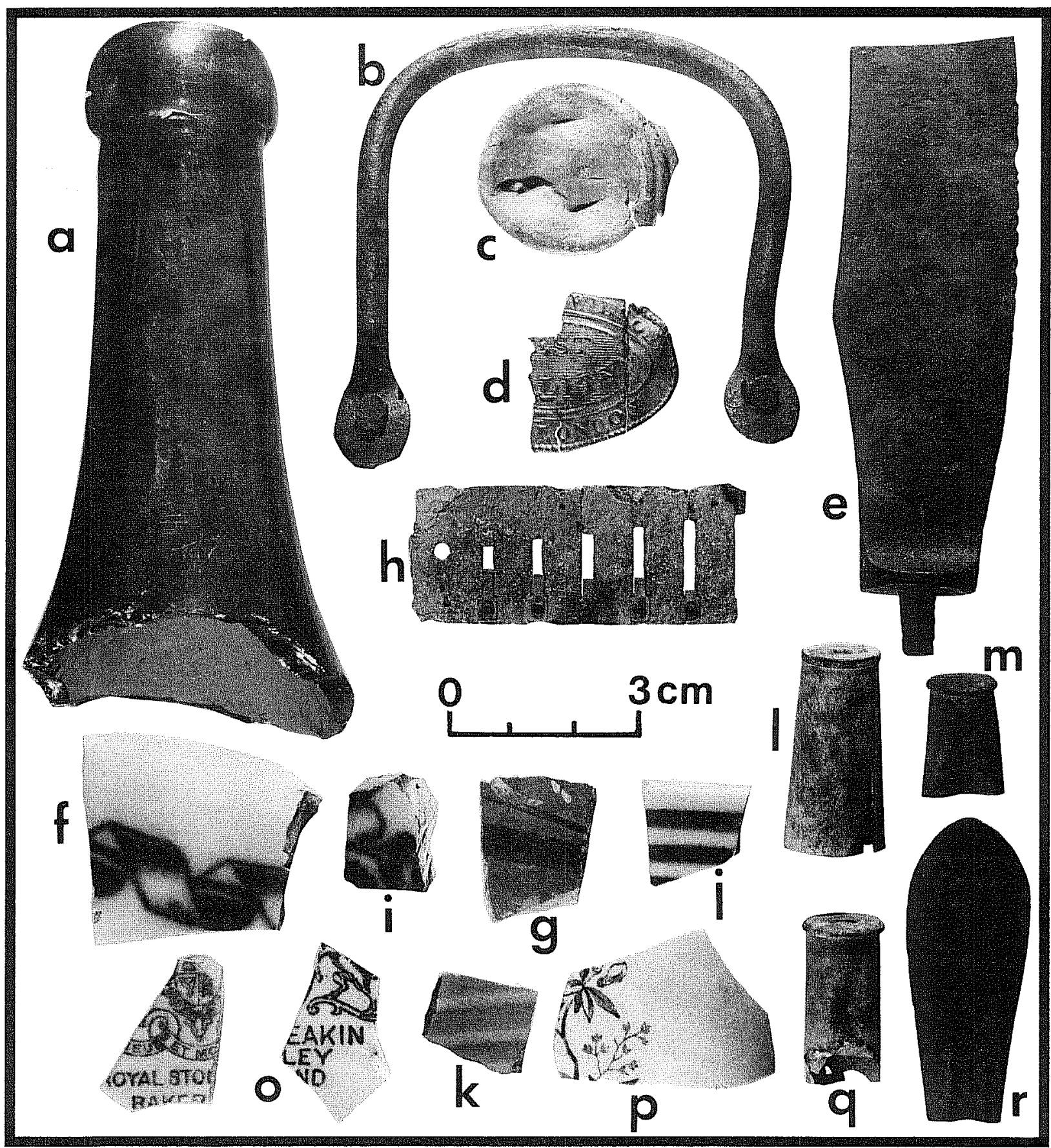

Figure 11. Surface and Subsurface Artifacts from Site 41MV199. a, whiskey bottle neck; b, metal comal handle; c, d, metal cap fragments; e, metal knife blade fragment; f, g, i, j, k, n, o, p, ceramic fragments; $h$, metal harmonica reed fragment; $1, q$, centerfire cartridges; $m$, rimfire cartridge; metal spoon handle fragment. 
and geographic definitions of archaeological sites made by both EHA in 1981 and CAR in 1992 were largely arbitrary.

Virtually all the prehistoric sites were open camps located on alluvial terraces or levees adjacent to either Elm Creek or unnamed tributaries of Elm Creek. An exception is 41MV181, which was situated on an upland or secondary terrace of Elm Creek several hundred meters from the channel. At the time of the CAR survey, the typical vegetation of all the alluvial floodplain sites was thornbrush and prickly pear thicket that varied substantially in density with location. Also, nearly all the sites were in active cattle pastures. These types of sites in the South Texas Plains area are usually remnants of occupations or activities by the nomadic hunting-gathering ancestors of peoples known during the Historic period collectively as Coahuiltecans, or perhaps by one or more of the other historic Indian groups (e.g., Lipan or Mescalero Apaches, Jumanos, Comanches) that frequented the area.

Apparently the prehistoric floodplain sites were the primary occupation and tool-finishing areas since most of the projectile points and other time-diagnostic or bifacial stone tools were found at those sites (cf. Montgomery 1978:21). Nevertheless, 41MV181 (the single upland terrace site not immediately proximate to a recognizable potential water source) also yielded surface finds of many points and other bifacial tools. It may have been a preferred upland occupation site because of the panoramic view it offers of the valley below and of the surrounding hills. The locale is an excellent long-distance look-out or observation post.

Site 41MV199 had foundation and collapsed-wall remnants of several small stone structures. Also on its surface were significant scatters of mid-to-late-nineteenth-century/early-twentieth-century age cultural material (primarily ceramic, glass, and metal fragments). Similar materials, including some butchered animal bone fragments, were recovered from the shovel test at the site. Though it was on the Kincaid Ranch, neither James Kincaid nor the ranch manager, Hodge Lord, knew anything definite about its origins and no reliable information concerning the site was obtained during the Phase II work. The impression of the CAR team in the field was that it may have been associated with the laying of the nearby section of the Southern Pacific Railroad (perhaps having been a railroad construction camp) during the early 1880 s; however, subsequent analysis of artifacts from the site suggested that it was probably the remnant of a late-nineteenth to early-twentieth-century-age ranch work camp.

Eight of the 33 sites examined by CAR during Phase II were particularly significant, so are discussed in some detail.

\section{$41 \mathrm{MV} 160$ and $41 \mathrm{MV} 161$}

Sites 41MV160, 41MV161, and 41MV159 were probably once one large site. They were situated in Area B on the primary terrace on the west side of an unnamed tributary of Elm Creek just east of the western permit boundary line (Figures 2 and 12). The locale is part of the Los Cuatros Ranch. The tributary source was about $12 \mathrm{~km}$ north-northwest of the sites, direction of flow was basically north-tosouth, and average channel floor width in the vicinity of the sites was about 3-5 m. Relatively short, wide arroyos dissected the terrace laterally with respect to the main tributary and formed geomorphically isolated remnants where each of the sites was located. The site surfaces were several meters above the tributary channel floor and the terrace alluvium consisted primarily of uniformly fine-textured and lighttan-colored sandy-clay loams. The terraces were underlain by a layer of well-rounded (mostly limestone) cobbles, the lag and gravel-bar deposits of previous channels. 
This page has been

redacted because it

contains restricted

information. 
The surfaces at the two sites sloped gently away from the main tributary for about 50-100 m until they adjoined the bases of secondary terraces or hilly uplands. The latter had relatively steep side slopes, with tops about 6-8 $\mathrm{m}$ higher above the tributary channel than those of the primary terraces. The secondary terraces also contained higher proportions of (mostly chert or quartzite) pebbles and gravels, and some small boulders. Since the backhoe trench at $41 \mathrm{MV} 160$ encountered a distinct layer of cultural material at about $47 \mathrm{~cm}$ below the primary terrace surface, it appears there was an earlier human occupation followed by substantial natural terrace aggradation which was, in turn, succeeded by a later human occupation represented by the surface and near-surface artifacts at the site.

Time-diagnostic surface artifacts collected at 41MV160 were Transitional Archaic in age and seemed to be eroding directly from reasonably well-preserved archaeological deposits, suggesting that the lower cultural layers at the site were probably at least Middle Archaic and perhaps even Early Archaic or Late Paleo-Indian in age. This interpretation is also supported to some extent by the fact that the lower layer of cultural material was just above the basal limestone stream gravels. Unfortunately, no time-diagnostic artifacts were found in the one backhoe test trench dug and time limitations precluded additional backhoe excavations at the site during Phase II.

When the sites were visited by the CAR field team, moderately dense surface scatters of cultural material interspersed with heavier concentrations of midden rocks and stone tool chipping debris were present. Dart points of the Almagre and Marcos types (Figure 4:a; Figure 5:f) were found on the surface at 41MV161. At 41MV160, the most intensively examined of the sites, dart points or dart point fragments of the Ensor and Frio varieties (Figure 4:m; Figure 5:a) were found among the debris. Most of the surface artifact scatters were within about the first 20-25 $\mathrm{m}$ of the channel bank and were exposed on the bank face and also on the primary terrace surface.

At both sites, low-density scatters of artifacts (mostly chert debitage) extended across virtually the entire primary terrace surfaces. Also, enough cultural material was located on the slopes and floors of the arroyos between the sites to indicate basic continuity between them, and with 41MV159 as well. The overall appearance of each site was that of a typical central or south Texas prehistoric burned-rock terrace-midden.

With regard to erosional processes, the adjacent tributary was not perennially flowing but the terraces containing the sites were being slowly degraded by periodic flooding and colluvial erosion. There were numerous rills and microscarps on the primary terrace and the areas of most severe erosion corresponded to the zones of maximum artifact exposure. Little indication of animal burrowing and virtually no evidence of artificial disturbances were observed at the sites. The best-preserved cultural strata may be located within the primary terrace at some distance from the main tributary channel, possibly even near the base of the secondary terrace. Sites $41 \mathrm{MV} 159,41 \mathrm{MV} 160$, and $41 \mathrm{MV} 161$ were probably contiguous for a significant period during prehistory; however, $41 \mathrm{MV} 159$ had been severely eroded by the time it was examined by the CAR field team and was therefore not considered to be archaeologically important. This interpretation was supported by both shovel and backhoe test excavations conducted at the sites during the Phase II survey.

\section{$\underline{41 M V 185}$}

$41 \mathrm{MV} 185$ is a burned-rock midden alluvial site (about $10 \times 40 \mathrm{~m}$ ) situated in Area A within the natural levee on the northeastern side of an unnamed tributary of Elm Creek. It was within the Kincaid Ranch property near the intersection of the tributary with an unpaved ranch road (Figures 2 and 13). Soils and vegetation were fairly typical for a floodplain site in that area. The dominant floral species were 
This page has been

redacted because it

contains restricted

information. 
mesquite and huisache. The gently rising levee was only a few meters wide, on average, and the heaviest concentrations of midden materials were mostly confined to its surface. The direction of flow of the tributary was from roughly northwest-to-southeast, its source was about $300 \mathrm{~m}$ to the northwest of the site (near 41MV189), and its confluence with Elm Creek was about 150-200 m to the southeast of the site.

Surface cultural features present at the site consisted of relatively heavy concentrations of burned rocks, chert debitage, and land snail and freshwater mussel shell fragments. Diagnostic stone tools from the surface include dart points or fragments of dart points of the Castroville, Conejo, Edgewood, Matamoros, and Palmillas types (Figure 4:e,f,h; Figure 5:e,j,m); three dart point preforms (Figure 7:c,d,e); and two arrowpoint preforms (Figure $6: \mathrm{q}, \mathrm{t}$ ). Shovel tests revealed the presence of cultural material at the site to depths of about $0.5 \mathrm{~m}$. The single backhoe test at the site was located amidst one of the heaviest surface concentrations and exposed a sizeable (several meters wide) ash-stained pit that appeared to be of considerable antiquity. The portion of the pit examined contained widely dispersed charcoal flecks and chert flakes and chips, and was situated at about $20-50 \mathrm{~cm}$ depth in the test trench profile.

Preservation appeared to have been fairly good. The ranch road passing through the site was only about two meters wide, was oriented roughly perpendicular to the tributary and levee, and did not have an elaborately prepared or deeply bladed bed. There was no visible evidence of disturbances from brush chaining, root plowing, or soil terracing and few animal burrows were present. Nevertheless, it was clear that sheet erosion was slowly depleting the archaeological deposits at the site.

\section{MV186}

Prehistoric site 41MV186 was located in the fossil floodplain of Elm Creek about 750-800 m northnorthwest from the most proximate portion of the existing creek channel. The site was in Area A, within the Kincaid Ranch property, about 30-50 m east of the Southern.Pacific Railroad track and about 1.90 $\mathrm{km}$ from the intersection of the track with the northern permit boundary line (Figures 2 and 14). The site rose as a slight knoll above the surrounding grade, which sloped gently downward to the east toward a narrow, shallow, soil-lined tributary of Elm Creek. Toward the west, the terrain gradually rose in elevation until it intersected the steep slopes of the upland terraces several hundred meters distant.

The source of the tributary was only about $100 \mathrm{~m}$ north of the site and the trend and direction of flow was roughly from north to south. It held small pools of standing water at the time of the CAR survey and intersected Elm Creek about $750 \mathrm{~m}$ south-southeast of the site. Vegetation near the site was mixed thornbrush and prickly pear interspersed with stands of mesquite and huisache that were taller and thicker toward the tributary. Soils in the vicinity were typical floodplain sandy and clayey loams. Surface cultural features at the site consisted of moderate-to-high-density scatters of burned rock, chert debitage, and other typical midden materials. These were exposed over a zone approximately $30 \mathrm{~m}$ north-to-south by $15 \mathrm{~m}$ east-to-west. Within this zone were several small (maximum dimensions about one meter) irregular-shaped concentrations of burned stones that were probably remnants of Late Prehistoric or Historic period Indian hearths (Figure 15). Some of the stones were contiguous or nearly-contiguous fragments of once-larger slabs and cobbles that had apparently been heat-fractured, thus supporting the notion that the arrangements were relatively undisturbed (cf. Varner 1968:56).

Two Angostura dart point proximal fragments (Figure 4:b,c) were found on the site's surface. One of the fragments had been reworked into a drill or perforator, thus suggesting it may have been imported to the site and reused during post-Paleo-Indian times. Both of the fragments exhibited basal and proximal-lateral-edge grinding and the precision flaking patterns characteristic of Paleo-Indian projectile 
This page has been

redacted because it

contains restricted

information. 

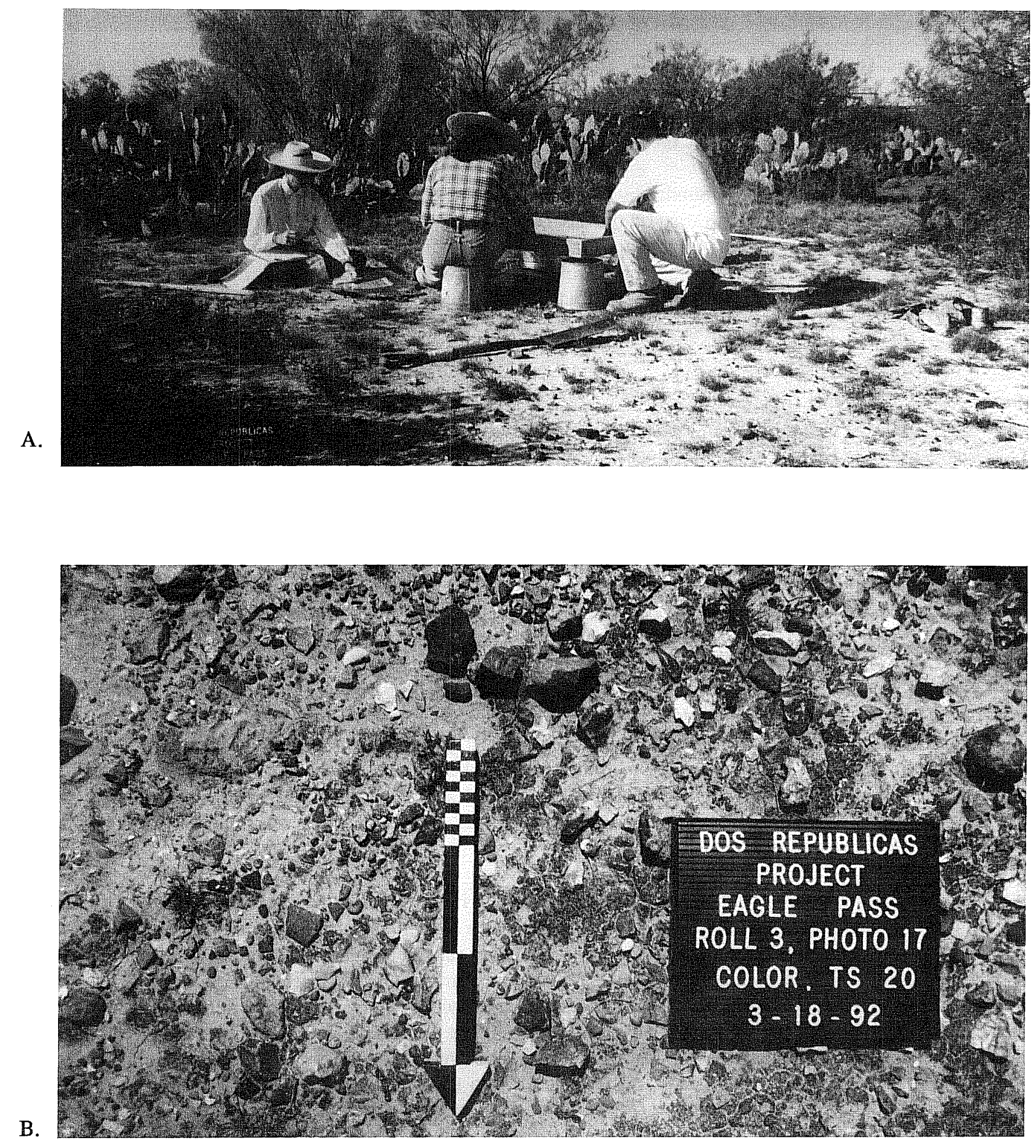

Figure 15. The Survey Area. A. Typical landscape of the Dos Republicas project area. CAR field crew members excavating and recording shovel test at site 41MV185. B. Typical hearth remnant. Closeup of burned and chipped stone on surface at site $41 \mathrm{MV} 186$. North arrow-scale is approximately $30 \mathrm{~cm}$ in length. 
points. In spite of the possibility they are out of their original temporal contexts, their presence at the site (and the fact that the site was somewhat higher in elevation and further from Elm Creek than most other prehistoric sites in the vicinity), strengthens the likelihood that 41 MV186 may contain a PaleoIndian occupational component. Langtry and Paisano dart point fragments (Figure 5:c,g), an unidentified dart point fragment, and a dart point preform (Figure 7:b) were also found, thus extending the range of probable cultural affiliations for the site to the Archaic period.

Although it was virtually surrounded by modern disturbances (a large stock tank to the south, the railroad track on the west, and a ranch road on the east), the site appeared to be relatively well-preserved. There was little evidence of animal burrowing or similar natural disturbances; however, colluvial erosion was slowly degrading the surface. Shovel tests revealed a paucity of subsurface cultural material in the areas tested, but the presence of what were apparently intact hearth remnants on the surface indicated the site may have substantial archaeological merit.

\section{MV187}

Site 41MV187 was located in Area A, within the Kincaid Ranch, close to the midpoint of the straight segment of the eastern boundary line of the permit area (Figures 2 and 16). It was on the northeast side of a slough (an old channel swale of Elm Creek) on the primary terrace about two meters above the slough bottom. The slough was dry at the time of the CAR investigations, and the eastern edge of Elm Creek was about $50 \mathrm{~m}$ west of the site. Both the slough and Elm Creek trended essentially north-tosouth. The fossil floodplain of Elm Creek extended at least $150 \mathrm{~m}$ to the east before reaching the hilly uplands. Soils and vegetation consisted of sandy-clay loam terrace beds covered with prickly pear and thornbrush; however, the slough to the south and west of the site was a heavily deflated and bioturbated marsh zone of clay bogs, undulating hillocks, and abundant strawgrass (sacahuista).

Surface archaeological features were distributed lengthwise along the edge of the slough for about 60-80 $\mathrm{m}$ over an area about $15 \mathrm{~m}$ wide. There were two distinct zones of cultural material: (1) the terraceslope zone containing several shallow, concentrated, irregular clusters of burned rocks, chert chipping debris, mussel shell fragments, and one burned animal bone fragment; and (2) the terrace-top zone that had several well-preserved Indian hearth remnants and a tight cluster of chipping debris. The latter features were amidst less dense scatters of cultural debris, mostly burned rocks and chert debitage, with some land snail shell fragments.

The hearth remnants were similar to those found at site 41MV186. The debitage cluster, containing about a dozen varieties of chert, appeared to be a remnant of a stone tool finishing station (cf. Hester 1978:2930). It was comprised of approximately several hundred relatively small tertiary or biface-thinning flakes (including many blade and lipped flakes) in a circular area on the surface about $30-50 \mathrm{~cm}$ in diameter. An Edgewood dart point (Figure 4:i) and a Perdiz arrowpoint (Figure 6:a) were within the concentration, and a Figueroa dart point (or Zavala arrowpoint; Figure 4:r) was found a few meters to the east. A Fairland dart point (Figure 4:0) was also found about $30 \mathrm{~m}$ to the north. Surface finds in other areas of the site included a Palmillas dart point (Figure 5:i), an unidentified projectile point proximal fragment (Figure 5:n), a Scallorn arrowpoint (Figure 6:h), and two arrowpoint preforms (Figure 6:s,v).

Since the chipped stone feature appeared to be relatively unique, well-preserved, and in imminent danger of being removed by non-archaeological means, it was mitigated extemporaneously by the CAR field team. A salvage (hand) excavation was begun at the surface level in the approximate center of the cluster and was continued outward and downward (about one meter in diameter and $10 \mathrm{~cm}$ deep) into the surrounding sterile soil. 
This page has been

redacted because it

contains restricted

information. 
Although there were several relatively well-preserved archaeological features in the terrace-top zone of 41MV187, the site was being slowly dissected from west to east by the headward erosion of some small arroyos that drained into the slough. In addition, both colluvial and slope erosion were gradually depleting the archaeological resources present, and the site was being used as a staging area for modern deer hunting activities (as evidenced by a 55-gallon steel drum deer feeder located there). Both shovel tests and a backhoe test indicated subsurface cultural material was confined mostly to the upper 20-30 cm of alluvium. The results of those tests, and of controlled surface examinations and collections, implied the site contained at least two distinct cultural components: (1) a Transitional Archaic or Late Prehistoric period occupation represented by the cultural material eroding from the terrace slope, and (2) a succeeding Late Prehistoric or Historic period (Indian) occupation represented by the terrace-top cultural debris. This multicomponent configuration clearly underscores the site's potential value as an archaeological resource.

\section{$41 \mathrm{MV} 189$}

Site 41MV189 was in Area A (Kincaid Ranch). Most of it was contained within a terrace-levee about $300 \mathrm{~m}$ northwest of $41 \mathrm{MV} 185$ on the opposite or west bank of the same unnamed tributary adjacent to the latter site (Figures 2 and 13). An unpaved ranch road connected a location along Elm Creek about $550 \mathrm{~m}$ east of $41 \mathrm{MV} 189$ to some stock pens about $30 \mathrm{~m}$ west of the site. Although a moderate-to-lowdensity scatter of stone artifacts extended for perhaps a $100 \mathrm{~m}$ radius from the tributary-road intersection, the majority of the surface artifacts were confined to an area approximately $15 \mathrm{~m}$ by $50 \mathrm{~m}$ adjacent to the tributary channel. Soils and vegetation were typical for the area.

The diagnostic cultural material discovered on the surface included Archaic period dart points or fragments of dart points of the Bell (Figure 4:d), Ensor (Figure 4:k,l), Figueroa (Figure 4:q), Frio (Figure 5:b), Langtry (Figure 5:d), Paisano (Figure 5:h), and Pedernales (Figure 5:1) types; a Marcos-like projectile point (Figure 5:0); and a finely retouched unifacial flake scraper (Figure 6:x). They were dispersed among dense isolated scatters of burned rocks and chert debitage.

Shovel tests and the one backhoe test conducted revealed that in the areas tested, the cultural strata were very shallow ( $<20 \mathrm{~cm}$ in depth); nevertheless, some well-preserved subsurface archaeological features may be present. Although 41MV189 and $41 \mathrm{MV} 185$ are probably contiguous, they were arbitrarily divided during the field survey to expedite documentation. What appear to be intact subsurface cultural features were discovered at 41MV185, and since that site and 41MV189 seem to be relatively undisturbed by modern human activities and seem to have similar morphologies, it is probable that they would have similar contents.

\section{$41 \mathrm{MV} 193$}

41MV193, a large floodplain site (cf. Montgomery 1978:2), was adjacent to and on the east side of Elm Creek and was circumscribed by a westward-bowing meander of the creek (Figures 2 and 17). It was in Area $\mathrm{A}$ and within the Kincaid Ranch. Its north-south axis extended about $800 \mathrm{~m}$ south from a point along the creek about $450 \mathrm{~m}$ south of the intersection of the creek and the northern boundary line of the permit area. On an east-west axis, its maximum breadth extended from the westernmost point along the creek meander (about $550 \mathrm{~m}$ from the east boundary line of the permit area) for about $400 \mathrm{~m}$ to the east. The site encompassed roughly 32 ha (80 a) of land. Soils and vegetation in the vicinity consisted of fairly thick alluvial terrace deposits of sandy-clay loam that rose several meters above the floor of Elm Creek and were covered by stands of thornbrush and prickly pear cactus. 
This page has been

redacted because it

contains restricted

information. 
Cultural material was scattered in moderate to low densities over the entire surface of the site amidst heavier concentrations of burned rocks containing chert debitage and tools, cores and hammerstones, and freshwater mussel and land snail shells. The quantity of unbroken mussel valves on the surface was markedly higher than at any of the other sites examined during the project (Hester [1976b:7] has noted that mussels were probably heavily exploited at many prehistoric sites on the Mexican side of the Rio Grande below Eagle Pass.). Unfortunately, time did not permit a thorough surface examination or any shovel or backhoe tests at the site, which was discovered late on the last day of field work. The backhoe services had been terminated and most of the CAR field crew had been dismissed from the project and had returned to San Antonio by that time; however, a skeleton crew comprised of Herbert G. Uecker and Clinton M. M. McKenzie undertook a preliminary pedestrian survey and artifact collection. Dart points of the Conejo (Figure 4:g), Ensor (Figure 4:j,n), and Figueroa (Figure 4:p), types; an unidentified dart point (Figure 5:p); and arrowpoints of the Sabinal (Figure 6:c), Scallorn (Figure 6:g), and Zavala types (Figure 6:n) were found on the surface of the site. Also found on the site's surface were two small, unidentified, thick $(>1.0 \mathrm{~cm}$ ) unifacial tools (Figure 7:f,g). One of the latter (Figure 7:f) appears to have been suitable for use as a perforator.

Most of the heavier surface scatters of midden material seemed to have been substantially deflated; however, some reasonably well-preserved Indian hearth remnants were noticed. The site did not appear to have been radically disturbed by modern human activities, but evidence of natural colluvial erosion, stream degradation, and rill and arroyo formation was present. It will not be possible to make a complete evaluation of the site's cultural assets without further archaeological work; however, the preliminary examination indicates that the site is significant.

\section{$\underline{41 M V 199}$}

41MV199 was the only historic-age archaeological site found during the CAR Phase II investigations. It was located on a floodplain flat, about $300 \mathrm{~m}$ north of the confluence of two unnamed tributaries of Elm Creek, about $460 \mathrm{~m}$ south of the northern permit boundary line, and about $215 \mathrm{~m}$ east of the Southern Pacific Railroad track (Figures 2 and 18). Soils were typical area sandy-clay loams; the dominant vegetation consisted of thick, tall stands of mesquite and huisache.

Artifacts (Figure 11) and remnants of structures from the site fall within the mid-to-late-nineteenth century to early-twentieth century time frame. Portable items consisted mostly of kitchen or cooking paraphernalia, including metal pot fragments; a metal comal handle; a metal spoon handle fragment; and sherds of transferware, banded slip, lead glaze, iron stone, stoneware, whiteware, and milkglass (Anne Fox, personal communication 1992). There were also glass wine and whiskey bottle fragments; a metal harmonica reed segment; metal bottle caps; and general construction and agricultural debris in the form of metal spikes (square), bolts, brackets, and a metal hoe blade. A few plain buttons were the only clothing items found. Also, several gun cartridge fragments were found. This assemblage, with its paucity of artifacts that could be clearly or exclusively associated with the presence of women, lends credence to the suggestion the site was a male work camp, possibly for construction of the railroad, but more likely a ranch camp. Unfortunately, nothing certain was discovered concerning the history of the site during the Phase II work.

Near one of the stone foundations, a shovel test was excavated to a depth of about $40 \mathrm{~cm}$ within a surface scatter of container glass and whiteware sherds which was apparently the upper remnant of a shallow trash pit. Several types of Historic period cultural material, including butchered and burned bone fragments, charcoal, glass and ceramic fragments, square nails, and gun cartridges, were collected from 
This page has been

redacted because it

contains restricted

information. 
the $0-10 \mathrm{~cm}$ level. Chipped stone fragments, including two tertiary flakes, were found below the historic age items to a depth of $40 \mathrm{~cm}$.

Preservation of some of the architectural remnants seemed reasonably good; several foundation outlines comprised of stone blocks were visible on the surface. If any archival records exist for the site, it may be possible to add to its recorded history through archaeological excavations. If no archival records are found, archaeological excavations might reveal its origin and purpose.

\section{OTHER PHASE II SITES}

In addition to the eight sites described previously, 25 (41MV139, 41MV158, 41MV159, 41MV167, 41MV174-84, 41MV188, 41MV190, 41MV192, 41MV194-198, and 41MV200) were examined by CAR during Phase II. Virtually all known data regarding these sites are presented in Table 2. Since many of the sites were in areas known to have been radically disturbed by modern soil conservation and agricultural practices or were otherwise poorly preserved, and since Phase II field time was relatively limited, archaeological field investigations were concentrated elsewhere and full recording and mapping of the sites was deferred to a future phase of work. Some of these sites were shovel and backhoe tested and enough data was gathered to prepare schematic maps (Figures 19-30) from field notes. 
This page has been

redacted because it

contains restricted

information. 
This page has been

redacted because it

contains restricted

information. 
This page has been

redacted because it

contains restricted

information. 
This page has been

redacted because it

contains restricted

information. 
This page has been

redacted because it

contains restricted

information. 
This page has been

redacted because it

contains restricted

information. 
This page has been

redacted because it

contains restricted

information. 
This page has been

redacted because it

contains restricted

information. 
This page has been

redacted because it

contains restricted

information. 
This page has been

redacted because it

contains restricted

information. 
This page has been

redacted because it

contains restricted

information. 
This page has been

redacted because it

contains restricted

information. 


\section{CONCLUSIONS}

\section{COMMENTARY AND RECOMMENDATIONS}

Though many archaeological sites (Table 1) had been discovered and recorded within the southwest Texas/Rio Grande Plains areas prior to the CAR Dos Republicas Project investigations, only a few had been comprehensively investigated. Within Maverick County and the Eagle Pass/Dos Republicas Project vicinities, virtually no formal archaeological studies had been undertaken. Except for the 1981 EHA survey, none had focused on prehistoric archaeological sites situated along tributaries several kilometers from the Rio Grande. Thus a major supposition of the following recommendations was that in the early 1990s, there was a dearth of information on sites such as those located within the Dos Republicas permit boundary.

A second important assumption behind the recommendations is that sites within the area investigated probably represent a unique cultural manifestation within Texas archaeology as a whole. The high spatial and temporal variability of natural resources and microenvironments and the steep ecological gradients present have fostered the development of diverse human adaptations in such areas during prehistory. The resulting archaeological sites appear as both large-scale (intersite) and fine-scale (intrasite and intracomponent) phenomena, and their value cannot always be accurately judged using criteria salient in other areas. For example, the criterion of depth-of-deposit is quite appropriate in central and east Texas, where aggradation on terraces of even minor streams during human prehistory was generally continuous and proceeded at rates sufficient to produce many deeply buried and well-stratified sites with multiple cultural components (distinctive human living floors). Such a criterion is clearly less germane to evaluating sites in the south and west Texas areas, where non-primary stream aggradation has proceeded at generally slower rates, or not at all, or where such stream terraces were degraded (cf. Black 1989:44).

The sites in the latter areas have a characteristic horizontal structure in which diagnostic artifacts from diverse time periods are often found on a common stratigraphic level (usually the surface or near-surface; cf. Hester 1976a:85, 1980:52-60; Hester and Hill 1975:20; Newton 1968:20, Figure 2; Varner 1968:61). In order to recover the maximum amount of cultural resource data, archaeological investigations of prehistoric, alluvial terrace sites in such areas must be tailored to those specific circumstances. In such cases the presence of thin, partially overlapping cultural zones (representing chronologically separate components) often make vertical excavations inappropriate:

... the excavation of buried occupation sites [in south Texas] is difficult, as large areas have to be excavated in order to recover enough artifacts and features (such as hearths and shell accumulations) to enable us to say something useful about the way people lived at the site. Because of the widely scattered nature of the buried remains, it is also hard to isolate a sequence of buried deposits and reconstruct the local culture history. We have found open area or block excavations to be the only way to obtain useful data from most south Texas sites [Hester 1980:60; cf. Hester 1976b:6,1978:41,1989:118; MacNeish 1958:174].

A third major premise of the recommendations given is that in spite of the impact of both natural and modern artificial disturbances, important information on past human cultures can probably still be gleaned from the types of sites under consideration here. Notwithstanding the toll that both ancient and modern artifact collectors, cattle ranching, sheet erosion, rilling, and arroyo formation have exacted, patterns of past human activities can often be discerned by careful investigators. This notion is supported by the findings of other archaeologists who have excavated similar sites in nearby areas of the South Texas 
Plains, "while disturbance at open area sites is often extensive, significant distributional evidence may still be present, and artifacts recovered from their relatively undisturbed contexts can indicate the patterned human behavior responsible for their existence" (Varner 1968:51; cf. Black 1989:44; Brown et al. 1982:13-18; Hester 1978:29-30,1980:59; Hester and Hill 1972,1975:7; Hill and Hester 1971; Montgomery 1978).

Given the probable validity of such assumptions; the fact that archaeological resources are nonrenewable; the fact that mining operations (especially at strip mines) frequently totally destroy the integrity and context of cultural resources; and the fact that all of the significant archaeological sites found by CAR during Phase II of the Dos Republicas Project investigations are within or near the primary mining impact zones; it is recommended that comprehensive cultural resource investigations of the following Dos Republicas Project sites, as described herein, be undertaken prior to any mining activities or other future artificial disturbances within the permit boundary (See Table 2 recommendations for all sites within the permit area.).

At sites 41MV160, 41MV161, 41MV185, 41MV186, 41MV187, 41MV189, and 41MV193 extensive controlled surface survey and intensive subsurface testing should be undertaken to further define the extent and content of the sites, and to determine the eligibility of the sites for nomination and listing in the National Register of Historic Places and/or for designation as state archaeological landmarks. Specifically, precise mapping, machine (backhoe) test-trenching, and carefully controlled manual testexcavations should be employed at each of these sites. These types of investigations would probably require a field crew of about eight professional archaeologists for a minimum average period of ten days at each site, as well as appropriate laboratory and report-preparation time. A backhoe with an operator proficient at working with archaeologists would need to be available on-site during much or all of this period. Reasonable amounts of time and funds should be allocated in any budget for additional geomorphological studies; ethnobotanical and/or paleobotanical studies; phytolith, pollen, soil humate, flotation, or other specialized procedures or studies; and radiocarbon dating.

Because of the size of 41MV193, additional field crew and backhoe time will be needed to make a more precise Phase II-type examination and evaluation of the site prior to engaging in detailed investigations. This would probably require a minimum of nine person-days and three days of backhoe and operator time. Appropriate laboratory and report-preparation time for this task should also be allocated.

At 41MV199, archival and oral-history research, on-site limited subsurface archaeological testing, and possibly some mitigative excavations should be performed. The background investigations should consist of interviews with area residents, history buffs, and professional historians; and a search of local courthouse, title company, and similar records that relate to land ownership and use in the general area, as well as with specific regard to 41MV199. This procedure would require the services of a professional historic archaeologist/archival researcher, probably for a minimum of five days. Also, depending upon the results of the archival research, archaeological excavations to further define site extent and content, and to determine the eligibility of the site for nomination and listing in the National Register of Historic Places and/or for designation as a state archaeological landmark might be needed. An appropriate estimate of field time required for such excavations could only be determined after completion of the archival research and oral interviews.

Surface survey and limited subsurface testing of the portion of Area A omitted from the CAR Phase II work (Figure 2; about $40 \mathrm{ha}$ [100 a] on the floodplain of Elm Creek) will also need to be included in future work. A minimum of 20 person-days of field time, five days of backhoe and operator time, and appropriate laboratory time should be reserved for this facet of the next phase of investigations. 
Sufficient flexibility will need to be incorporated in any proposal for future work to cover reasonable contingencies. For example, should any significant sites be found in the area omitted from the Phase II pedestrian survey or any significant features be found during the intensive preliminary investigation of $41 \mathrm{MV} 193$, additional funding for the archaeological field crew, geomorphologist and other required specialists, backhoe and operator, and attendant laboratory and report preparation time necessary to mitigate these sites or features should be anticipated. An overriding consideration is the impossibility of predicting exactly what will be found during any archaeological investigation; therefore, the possibility exists that future work will have to be expanded beyond what has been outlined herein.

\section{RESEARCH PROBLEMS AND DESIGN FOR FUTURE WORK}

It was not feasible to present within this report a comprehensive review of research theory and problemoriented topics relating to the archaeology of the Dos Republicas Project area. In order to supply lay readers with some substantive knowledge of the types of problems that the discipline of archaeology confronts in such projects, and to set forth possible avenues of research for future Dos Republicas Project investigations, the following synopsis of research topics found in the archaeological literature and formulated during the CAR field work is offered. More detailed treatments of the research problems of south Texas prehistoric archaeology appear in Black (1989:57-62), Hall et al. (1982:473-478, 1986:406416), and Montgomery (1978:1). Also, Nunley (1975:46-47) and Warren (1989a:15-16) have presented brief outlines of research topics for the middle-Rio Grande area. Since the majority of sites to be investigated during the next phase are prehistoric, the synopsis focuses mainly on issues and problems of the prehistoric archaeology of the area.

For presentation purposes, Hester's (1980:31) definition of the culture area under consideration as the Rio Grande Plain (Figure 1) is adopted here, "the southern Texas-northeastern Mexico archaeological area . . . encompasses a region whose northern edge is along and just south of the Edwards Plateau and extending south into adjacent portions of northeast Mexico. The south Texas sector, consisting of 22.5 million acres . . . is often referred to as the 'Rio Grande Plain'. . ." (cf. Black 1989:39, Figure 19; Hester 1980:31, Figure 2.1; Montgomery 1978:Map 1; Newcomb 1956, 1961:29; Warren 1989a:12 and Figure 7, 1989b):

Since Hester has probably researched the prehistoric archaeology of the area more thoroughly than most other professional archaeologists to date, many theoretical concepts expounded here were initially developed or first introduced to the literature by him, or by students and colleagues working under his aegis. Nevertheless, several other researchers have contributed to the body of knowledge on the archaeology of the area and references to their findings or interpretations are also cited.

Major themes in the study of the prehistoric archaeology of the middle-Rio Grande area have included: (1) the definition of the area as a distinct geographic and cultural phenomenon and of its diagnostic cultural traits and patterns; (2) the determination of a regional cultural chronology or culture history; (3) the revelation of specific human adaptations to past natural environments and of supporting technologies; and (4) the explication of cultural processes and changes over time. Each category has numerous intertwined aspects which, at this stage, need further investigation, and many approaches must often be subsumed within a single research effort to obtain optimum results. Coloring all studies of the prehistoric hunting and gathering peoples of the area is the fact that almost everything that can be learned about them is contained within their ancient trash piles. The latter consist mostly of stone, bone, shell, and ceramic

fragments. Many middens have not survived to the present time in a good state of preservation; the few that have are continually threatened or destroyed by modern human activities. Also, all nonmaterial 
aspects of the area's prehistoric cultures (such as social, political, and economic organization; and ideology, religion, and cosmology) must be inferred from examination of these meager tangible remnants. Under such circumstances, the contract archaeologist, who is often doing what is essentially salvage archaeology under tight scheduling and other adverse field situations, must be extraordinarily diligent in order to recover meaningful data.

Regarding the cultural identity of the area, Nunley (1975:43-45) compared the archaeological remains from both sides of the Rio Grande and made tentative conclusions regarding the local prehistoric human settlement patterns and occupation densities (cf. Hester 1976b:4; Hester and Hill 1975:21):

The distribution of prehistoric sites [in Mexico] seems to be essentially the same as in southwestern Texas. That is, habitation sites tend to parallel streams, while utility sites such as quarry or kill sites are found at opportunistic locations.

Judging by both the close proximity to one another and the relatively large extent of these Mexican sites, the density of prehistoric occupation was greater in northern Coahuila than across the river in southern Texas. Although very large sites (over $500 \mathrm{~m}$ in length) are common on both sides of the Rio Grande, such sites are more frequent in areas visited in Coahuila than in adjacent areas of Texas.

. . . observations of artifacts at the [prehistoric Mexican] sites visited plus study of collections previously made by amateurs from both Mexico and the United States strongly suggest both quantitative and qualitative differences in lithic technology and typology from similar sites on the United States side of the Rio Grande. This suggests the unusual situation of separate, and different, sociocultural groups on opposite sides of the river in prehistoric times.

Nunley (1977:5-10) later expands his discussion:

Although we spent approximately as much time in Texas as in Mexico, we found a disproportionately large number of [prehistoric] sites in Mexico. The Mexican sites are, generally speaking, far more extensive than those on the U.S. side. It is not unusual to find continuous occupation areas extending for more than a kilometer along a major stream in the Coahuila portion of the study area. Although similarly extensive sites are commonly found in south Texas, none was found in the area of Texas visited in this study.

Quick comparison with Hester's material from just east of the target area, as well as material from Amistad similarly indicates the distinctiveness of the material we have collected in the course of this project. This material ... I have chosen to call the Castaña Complex. The people of the Castaña Complex lived in large, relatively sedentary encampments on the Mexican side of the Rio Grande in the vicinity of the Arroyo Castaña. I believe these people to have achieved a unique and stable relationship with their environment for a period of time during what has been termed the Middle Archaic. They occupied a unique environmental niche--a part of the Rio Grande that has only very brief northern laterals but numerous crossing points. 
Comparison of the Castaña Complex with Hester's Late Archaic indicates that the Late Archaic never reached the area in significant degree. Similar comparison with lithic material from the excavated missions shows no technological or typological similarity.

I submit, therefore, that the Castaña Complex in particular and the Archaic in general was absent from the area long before the earliest Spanish entradas and that the Valle de Circumsision and the area along the Arroyo Castaña were virtually uninhabited at the time the missions were established. Such inhabitants as were there were themselves recent arrivals.

Thus the gap between the Archaic and ethnohistory in the Gateway area is clear--the relationship between the historic and aboriginal populations is mainly a matter of chronological sequence and geographic coincidence. Once again we seem to be denied the luxury of associating a prehistoric entity with history [emphasis added].

Nunley (1977:7) also observed that many chipped stone tools at Mexican sites in the vicinity are made of chert which only occurs naturally in Texas. Similarly, Hester (1989:119) found obsidian, obtained from a Mexican source $1,000 \mathrm{~km}$ distant (identified as such by neutron-activation chemical-trace analysis), at a prehistoric archaeological site in Uvalde County. Additionally, Hester referred to some outstanding similarities of Late Prehistoric period artifacts of the lower Pecos and southeastern Trans-Pecos areas with those of the Rio Grande Plain (Hester 1975b:20). Also, Hester and Hill (1975:23) postulated the presence of exchange vectors between south Texas, west Texas, the Texas coastal margin area, New Mexico, and Mexico during the Late Prehistoric period. Montgomery (1978:18-19; cf. Suhm et al. 1954) noted the presence of Almagre projectile points (which he believed to be associated primarily with the prehistoric peoples of Mexico) in archaeological sites along the Rio Grande in Texas and favorably compared the diagnostic projectile points of the Pecos River area to those of the Rio Grande Plain.

Apparently the prevailing view among archaeologists has been that prehistoric cultures of the middle-andlower Rio Grande areas formed a coherent tradition (or several integrally related traditions) which extended into relatively large portions of both Texas and Mexico, and that cultural evolution in the area was essentially gradual and uniform; however, these notions may need to be significantly revised. Perhaps the implications of the patterns of trade across the Rio Grande during prehistoric times should be more rigorously examined. It is noteworthy that the definition of the culture area which contains the Dos Republicas permit site may need refinement or reinforcement and that what ostensibly were distinct cultures on each side of the Rio Grande existed, commingled, and exchanged material goods. Any data that are forthcoming from local archaeological projects should be analyzed in the context of the culture area concept and for trade implications, and when possible, research should be predisposed toward those topics.

A related problem is that cultural chronologies conceived at the general level for south and southwest Texas many decades ago have still not been adequately refined at sub-regional and local levels. Regarding the sequence of South Texas Plains prehistory, ". . . chronologies are very well known for central Texas and for the lower Pecos, but very poorly understood for the south Texas plains. Similarly, typologies are well established in central and lower Pecos Texas, but are a real problem in south Texas where unstemmed point forms are dominant" (Hester 1989:118). 
Black (1989:57) lists five reasons for lack of progress in chronology and typology building in the area: "(1) poor preservation of organic material, (2) scarcity of buried sites, (3) dearth of excavated sites, (4) predominance of seemingly heterogeneous unstemmed lithic forms, and (5) systematic surface mining of all potentially diagnostic lithics by collectors . . .."

For the Rio Grande Plain area, the three-division areal chronology (consisting of the Paleo-American, Archaic, and Historic periods) of Suhm et al. (1954) has only been modestly revised and many central questions concerning the character and contents of the Late Prehistoric and Protohistoric periods apparently remain open. For example, the Late Prehistoric period in Texas has been traditionally perceived by archaeologists as part of a regional phenomenon of south-central and southwestern North America that began about A.D. 500-800 with the introduction of semi-permanent or permanent agricultural villages, ceramics, and the bow and arrow. In central Texas, based on extensive archaeological excavations, two distinctive phases of the Late Prehistoric period have been distinguished: the Austin phase (ca. A.D. 800-1200; diagnostically linked to finds of Scallorn arrowpoints within appropriate assemblages of other characteristic artifacts) and the Toyah phase (ca. A.D. 1200-1500; diagnostically linked to Perdiz arrowpoints within certain stratigraphic and associational settings). To date, there is no evidence of the contemporaniety of the two phases there.

By contrast, in the Rio Grande Plain area, Scallorn and Perdiz arrowpoints have been found in close mutual association within well-stratified and well-preserved archaeological deposits, and there is mounting evidence of the contemporaniety of both kinds of points with certain types of light weight dart points which are usually attributed to the Late Archaic period (cf. Hester and Hill 1972:57,1975:8,18; Montgomery 1978:141). There is speculation that the light weight projectile points which fall into the morphological range normally assigned to dart points, were actually used with the bow and arrow, or even contemporaneously used as both dart and arrow points (cf. Hester 1974b:21,1976b:5; Hester and Hill 1972:41; Hill and Hester 1971). If these associations are valid, do they reveal that in certain areas the use of conventional Archaic technologies continued into the Late Prehistoric (or even into the Historic) period as the terminus of a monotonous cultural tradition that lasted for many thousands of years (cf. Newcomb 1956), or merely that the widely accepted conceptual axioms and chronological nomenclature need revision (cf. Hester 1976b:9, 1981:Abstract; Newton 1968:21-22; Nunley and Hester 1975:93-94)? And what of the Protohistoric period, the time after the first Europeans had arrived in the general southwest North American area but had not made contact with Indians in certain isolated zones such as portions of southwest Texas and the Rio Grande Plain (cf. Hester and Hill 1975:19; Hill and Hester 1973)? Can its validity as a spatiotemporal and cultural construct be decisively demonstrated and can it be clearly recognized archaeologically? Fortunately, many archaeological sites in the Dos Republicas project area had what were apparently well-preserved Late Prehistoric or Historic Indian components which may have the potential to provide answers to such questions.

For at least the last several decades, archaeologists have understood the importance of detailed studies that examine the maximum variety of data to reconstruct the full environmental context of prehistoric human ecology and adaptive technology:

Local variations in rainfall, soils, vegetation, and related factors must be considered before the prehistoric adaptation patterns in a specific area can be understood. It has also been suggested that the data currently do not exist for most areas . . . [of south and central Texas] . . . that are adequate for detailed paleoenvironmental reconstructions. Thus, plans for future archeological investigations should always consider the potential for recovering environmental data [Black 1989:16]. 
For the Rio Grande Plain region, outstanding examples of paleoenvironmental topics are in need of further study. One is the issue of the morphology and function of the so-called hearths and other burnedrock features that are fairly ubiquitous in the area. These enigmatic features appear on the surface as small but conspicuous clusters of burned rocks and chert chipping debris in both intrasite or intersite (isolated) contexts (cf. Mallouf 1986:Figure 3; Nunley 1975:43; Nunley and Hester 1975:Figure 3, 1980:153-154; Warren 1989a:13). Archaeologists had found carbonized plant remains in association with several similar features in other parts of south Texas and in central Texas (cf. Hall et al. 1986:407; Hester 1985; Holloway 1986:437-451) but only very small samples of perishable materials had been found in hearths of the Rio Grande Plain area until Mariah Associates, Inc., of Austin, Texas, found a more substantial sample in Maverick County in 1991. A preliminary report on the discovery was published just prior to the CAR Dos Republicas Phase II investigations (Lintz 1991). This invaluable find included well-preserved carbonized remains of many local species of plants, thereby adding to the evidence that such hearths were used by prehistoric human groups throughout much of Texas primarily to prepare plant foods (cf. Black 1989:49-50; Hester 1981:126; Hester and Hill 1972:59-60; and Taylor 1972 who suggest that the wide-spread exploitation of plant foods by prehistoric peoples may have supported a marked population growth during the Middle Archaic and Late Prehistoric periods in south Texas). Nevertheless, it will be necessary to examine many more of these features (not yet discovered) to make their association primarily with plant food preparation viable, to establish such an association as an area-wide phenomenon, and to refine the inventory of plants exploited.

Analysis of botanical and paleobotanical data is a major approach to reconstructing the past climate and other environmental aspects of a given area (cf. Montgomery 1978:11). Probably because of soil fungal activity, alkalinity, and oxidation levels, pollen apparently does not preserve well on the Rio Grande Plain (Hester 1978:38), and carbonized plant remains from ancient hearths may be one of only a few sources of paleobotanical and ethnobotanical data for the area. Since many hearth-like features that are apparently in a reasonably good state of preservation were tentatively documented by the CAR field team in the Dos Republicas permit area, they will need careful investigation during future work (cf. Varner 1968:57-58).

Alston Thoms (personal communication 1992), archaeologist with Texas A\&M University, suggests Indians preferred silicate rocks such as sandstone, chert, or quartzite calcareous rocks such as limestones for hearth stones. This is because silicates are the most advantageous raw material for stone tool manufacturing (heat-treating often augments the knapping quality of chert) and because they retain heat longer than other naturally occurring materials and thus make better heating elements in earth ovens. Interestingly, the two layers of hearth stones (at the surface and at about $47 \mathrm{~cm}$ below the surface) documented at site 41MV160 during CAR Phase II work exhibited remarkable contrasts. The burned stones on the surface appeared to be almost entirely calcareous while those from the subsurface layer were virtually all silicious (quartzite). If, as is believed to be the case, the two layers represent separate human occupations widely separated chronologically, how can this disparity in the composition of hearth stones from the two strata be explained? Is it the result of natural or cultural conditions that have varied over time? In an appropriate effort to answer such questions, future work in the Dos Republicas permit area should be structured to thoroughly record and analyze both qualitative and quantitative variations in burned stone at prehistoric archaeological sites.

Based on archaeological work in south Texas spanning nearly three decades, Hester defined several natural microenvironments and attendant human adaptations within the area during prehistory (cf. Hester 1976b:5-10, 1989:123 and 127, 1981; Hester and Hill 1975:17; Newton 1968:24,Figure 4). He gradually discovered that while there are general similarities among a majority of prehistoric sites in the area, there are significant variations in artifact assemblages among some of the sites--even sites located in similar adjoining stream drainages. As data on artifact assemblages has accumulated, Hester's initial 
notion that area cultural manifestations represented only a few salient human adaptations has undergone substantial revision (Hester 1978:34-35).

For instance, in his earlier interpretations, Hester believed there was a relatively uniform morphological and functional dichotomy between floodplain sites and upland sites in south Texas. The former were large-scale, multiple-function occupational sites or base camps which often had appreciable depths-ofdeposit; the latter were small-scale, specialized-activity sites which were satellites of base camps, and were usually severely deflated by erosion (cf. Hester 1976b:6-7). The underlying assumption was small bands or populations of a particular human group utilized both kinds of sites in a given area simultaneously and seasonally (cf. Hester 1976b:7; Hester and Hill 1975:22). The subsequent discovery of massive, well-stratified, multiple-component upland sites with deep cultural deposits by Hester (1978:34, 1981:123-124) and of enigmatically located sites by Nunley (1975:42) suggested that site function was not always related to location in such a simplistic manner. While it seems there must have been substantial functional differences, even between contemporaneous sites with roughly similar internal morphologies and geomorphological contexts, the nature of those differences has yet to be fully elucidated. Again, the problem has been perpetuated by poor preservation of pollen and other perishables, and no doubt, a good deal of luck will be involved in its resolution. In any case, archaeological research in the area should be tempered with the knowledge that much remains to be done regarding site function and site classification. Future archaeological investigations of the Dos Republicas permit area may provide an excellent opportunity for enhancing our knowledge of these subjects.

Regarding the fourth major objective of archaeological investigations in the Rio Grande Plain area -- the explication of cultural processes and changes over time -- Montgomery, in the late 1970s, expressed the hope that archaeologists could soon progress beyond data-gathering and into the realm of interpreting cultural processes (the mechanisms and conditions responsible for cultural evolution). Unfortunately, this has not occurred on a broad scale because it requires a massive high-quality data base that does not yet exist for the area. Again, many archaeological sites in the area are poorly preserved or inaccessible. To date, excavations have occurred at only a handful of major prehistoric sites, notably the Mariposa site and the Stockley site, and in the case of the Stockley site, the data obtained still awaits full analysis and publication. As recently as the late 1980s, Black asserted:

In contrast to central Texas, the south Texas archaeological region . . . is one of the least known regions of the state. Only in recent decades have archaeological investigations begun in south Texas on a significant scale. Thus, in comparison with central Texas and the lower Pecos, much of the prehistory of south Texas remains either totally unknown or largely conjectural . . . Archaeological work along the middle-Rio Grande in south Texas has been very sporadic and the area remains very poorly known ... [Black 1989:39; cf. Hester and Eaton 1983; emphasis added].

The paucity of superlative excavations in the area is yet another reason for the undertaking of optimal future investigations at the Dos Republicas Project site.

These are only a few research topics pertinent to archaeological investigation in the area. Undoubtedly many other specific questions will surface as future work progresses. It will be the responsibility of the subsequent researchers to deal with such unforeseen issues extemporaneously and creatively in order to properly document and preserve the cultural resources of the proposed Dos Republicas coal mine. 


\section{REFERENCES CITED}

Adams, R. E. W., F. D. Almaraz, B. Davidson, J. D. Eaton, A. A. Fox, T. R. Hester, J. P. Nunley, and $\mathrm{F}$. Valdez. Jr.

1976 The Archaeology and Ethnohistory of the Gateway Area: Middle-Rio Grande of Texas. Report of the 1976 Investigations. Unpublished manuscript assembled by R. E. W. Adams and submitted to the National Endowment for the Humanities by the University of Texas at San Antonio, December, 1976. Photocopy on file at the Center for Archaeological Research, The University of Texas at San Antonio.

Adams, R. E. W., F. D. Almaraz, T. N. Campbell, J. D. Eaton, A. A. Fox, T. R. Hester, and J. P. Nunley

1977 The Archaeology and Ethnohistory of the Gateway Area: Middle-Rio Grande of Texas. Final report to the National Endowment for the Humanities, \#RO-21425-75-408. Unpublished manuscript assembled by R. E. W. Adams and submitted to the National Endowment for the Humanities by the University of Texas at San Antonio, December, 1976. Photocopy on file at The Center for Archaeological Research, The University of Texas at San Antonio.

Adams, R. E. W., J. D. Eaton, T. R. Hester, J. P. Nunley, and F. D. Almaraz

1975 The Archaeology and Ethnohistory of the Gateway Area: Middle-Rio Grande of Texas. Report of the 1975 Investigations. Unpublished manuscript assembled by R. E. W. Adams and submitted to the National Endowment for the Humanities by The University of Texas at San Antonio, December, 1975. Photocopy on file at the Center for Archaeological Research, The University of Texas at San Antonio.

Alexander, R. K.

1970 Archeological Excavations at Parida Cave, Val Verde County, Texas. Papers of the Texas Archeological Salvage Project 19. University of Texas, Austin.

Barlow, J. C., A. M. Powell, and B. N. Timmermann, eds.

1986 Invited Papers from the Second Symposium on Resources of the Chihuahuan Desert Region: United States and Mexico. Chihuahuan Desert Research Institute, Allen Press, Lawrence, Kansas.

Black, S. L.

1989 South Texas Plains. In From the Gulf Coast to the Rio Grande: Human Adaptation in Central, South, and Lower Pecos Texas by T. R. Hester, S. L. Black, D. G. Steele, B. W. Olive, A. A. Fox, K. J. Reinhard, and L. C. Bement, pp. 39-62. Arkansas Archeological Survey Research Series 33, Fayetteville.

Blair, W. F.

1950 The Biotic Provinces of Texas. Texas Journal of Science, 2(1):93-115.

Bowers, J. C.

1989100 Desert Wildflowers of the Southwest. Southwest Parks and Monuments Association. Tucson, Arizona. 
Brown, K. M.

1979 An Archaeological Reconnaissance of the Proposed Eagle Pass Municipal Airport Site, Maverick County, Texas. Archaeological Survey Report 87, Center for Archaeological Research, The University of Texas at San Antonio.

1991 Prehistoric Economics at Baker Cave: A Plan for Research. In Papers on Lower Pecos Prehistory, edited by S. A. Turpin, pp. 87-140. Studies in Archeology 8, Texas Archeological Research Laboratory, The University of Texas at Austin.

Brown, K. M., D. R. Potter, G. D. Hall, and S. L. Black

1982 Excavations at 41LK67, A Prehistoric Site in the Choke Canyon Reservoir, South Texas Choke Canyon Series 7, Center for Archaeological Research, The University of Texas at San Antonio.

Brune, G.

1981 Springs of Texas. Branch-Smith, Fort Worth.

Bruseth, J. E.

1991 Section 106: What is the SHPO Really Looking for in a Survey Report? Part 1: The Basic Elements. APR News and Views 3(2):15-16. Department of Archeological Planning and Review, Texas Historical Commission, Austin.

Bryant, V. M., Jr., and R. G. Holloway

1985 A Late Quaternary Paleoenvironmental Record of Texas: An Overview of the Pollen Evidence. In Pollen Records of Late Quaternary North American Sediments, pp. 39-70. American Association of Stratigraphic Palynologists Foundation, Dallas.

Bryant, V. M., Jr., and H. J. Shafer

1977 The Late Quaternary Paleoenvironment of Texas: A Model for the Archeologist. Bulletin of the Texas Archeological Society 48:1-26.

Bye, A. R., Jr.

1983 Vegetation and Soils. In Borderlands Sourcebook, A Guide to the Literature on Northern Mexico and the American Southwest, edited by E. R. Stoddard, R. L. Nostrand, and J. P. West, pp. 98-104. University of Oklahoma Press, Norman.

Campbell, T. N.

1979 Ethnohistoric Notes on Indian Groups Associated with Three Spanish Missions at Guerrero, Coahuila. Archaeology and History of the San Juan Bautista Mission Area, Coahuila and Texas 3, Center for Archaeological Research, The University of Texas at San Antonio.

1988 The Indians of Southern Texas and Northeastern Mexico: Selected Writings of Thomas Nolan Campbell. The University of Texas, Austin.

Campbell, T. N. and T. J. Campbell

1981 Historic Indians of the Choke Canyon Reservoir and Surrounding Area, Southern Texas. Choke Canyon Series I, Center for Archaeological Research, The University of Texas at San Antonio. 
Caran, S. C. and V. R. Baker

1986 Flooding Along the Balcones Escarpment, Central Texas. In The Balcones Escarpment: Geology, Hydrology, Ecology, and Social Development in Central Texas, edited by P. L. Abbott and C. M. Woodruff, Jr, pp. 1-14. Published for the Geological Society of America Annual Meeting, San Antonio, Texas, November, 1986. Printed by Comet Reproduction Service, Santa Fe Springs, California.

Chambers, W. T.

1946 The Geography of Texas. Steck Vaughn, Austin.

Crabtree, D. E.

1982 An Introduction to Flintworking. Occasional Papers of the Idaho Museum of Natural History, 28. Pocatello, Idaho.

Davis, D. R. , Jr.

1991 Prehistoric Artifacts of the Texas Indians: An Identification and Reference Guide. Pecos Publishing, San Antonio.

Dibble, D. S.

1965 Bonfire Shelter: A Stratified Bison Kill Site in the Amistad Reservoir Area, Val Verde County, Texas. Miscellaneous Papers 5, Texas Archeological Salvage Project, The University of Texas, Austin.

Duffield, L. F.

1970 Vertisols and Their Implications for Archaeological Research. American Anthropologist 72:1055-1062.

Eaton, J. D.

1975 Preliminary Report on Archaeological Investigations at San Bernardo, 1975. In Archaeology and Ethnohistory of the Gateway Area, Middle-Rio Grande of Texas: Report of the 1975 Investigations. Unpublished manuscript prepared by The University of Texas at San Antonio and submitted to the National Endowment for the Humanities. Photocopy on file at the Center for Archaeological Research, The University of Texas at San Antonio.

Eagle Pass Chamber of Commerce

ca. 1991 Unpublished and untitled photocopied sheets with information on the geography, history, demography, and climate of Maverick County. Obtained from the Eagle Pass Chamber of Commerce in 1992.

Elanco Range Products

ca. 1990 Rancher's Guide to Brush Management. Elanco Products Company. Indianapolis, Indiana.

Espey, Huston \& Associates, Inc.

1979 An Assessment of the Known Cultural Resources of the Middle-Rio Grande Area Prior to European Contact. Prepared through the cooperation of the United States Department of Housing and Urban Development for the Middle-Rio Grande Development Council, Del Rio, Texas. Ms. on file at the Texas Archeological Research Laboratory, The University of Texas, Austin. 
1981 A Cultural Resource Survey and Assessment of the Maverick County Coal Project. Unpublished report on file with the Texas Historical Commission, Austin.

Evans, T. J.

1974 Bituminous Coal in Texas. Bureau of Economic Geology Handbook 4. The University of Texas, Austin.

Fenneman, N. M.

1931 Physiography of Western United States. McGraw-Hill, New York.

Fischer, P. C.

198970 Common Cacti of the Southwest. Southwest Parks and Monuments Association, Tucson.

Fox, D. E.

1979 An Intensive Survey of Sixteen Prehistoric Archaeological Sites in Starr County, Texas. Archaeological Survey Report 72. Center for Archaeological Research, The University of Texas at San Antonio.

1983 Traces of Texas History: Archeological Evidence of the Past 450 Years. Corona Publishing, San Antonio.

Fox, D. E. and W. H. Whitsett

1979 An Archaeological Reconnaissance at Eagle Pass, Maverick County. Unpublished manuscript on file at the Center for Archaeological Research, The University of Texas at San Antonio.

Frkuska, A. J., E. C. Frkuska, D. Brown, and T. R. Hester

1977 Archaeological Test Excavations at 41MV57: The Seco Mines Project, Maverick County, Texas. Archaeological Survey Report 28, Center for Archaeological Research, The University of Texas at San Antonio.

Gomez, A. R.

1990 A Most Singular Country: A History of Occupation in the Big Bend. National Park Service, Department of the Interior, Santa Fe, New Mexico and Charles Redd Center for Western Studies, Brigham Young University.

Hall, G. D., S. L. Black, and C. Graves

1982 Archaeological Investigations at Choke Canyon Reservoir, South Texas: The Phase I Findings. Choke Canyon Series 5, Center for Archaeological Research, The University of Texas at San Antonio.

Hall, G. D., T. R. Hester, and S. L. Black

1986 The Prehistoric Sites at Choke Canyon Reservoir, Southern Texas: Results of Phase II Archaeological Investigations. Choke Canyon Series 10, Center for Archaeological Research, The University of Texas at San Antonio.

Hester, T. R.

1968 Paleo-Indian Artifacts from Sites Along San Miguel Creek: Atascosa, Frio, and McMullen Counties, Texas. Bulletin of the Texas Archeological Society 39:147-161. 
1971 Hunters and Gatherers of the Rio Grande Plain and the Lower Coast of Texas. Paper presented at the annual meeting of the Texas Academy of Science, Nacogdoches.

1974a Prehistoric Subsistence and Settlement Systems on the Rio Grande Plain, Southern Texas. Yearbook of the American Philosophical Society 1973, pp. 594-596.

1974b Some Observations on Archaeology at Chaparrosa Ranch, 1974. La Tierra 1 (3):19-22.

1975a Chipped Stone Industries on the Rio Grande Plain, Texas: Some Preliminary Observations. Texas Journal of Science 26(1-2):213-222.

1975b Late Prehistoric Cultural Patterns along the Lower Rio Grande of Texas. Bulletin of the Texas Archeological Society 46:107-125.

1975c Material Culture at San Bernardo: Preliminary Comments. In Archaeology and History of the Gateway Area, Middle-Rio Grande of Texas, pp. 23-36. Report submitted to the National Endowment for the Humanities by The University of Texas at San Antonio. Mimeographed.

1976a The Archaic of Southern Texas. In The Texas Archaic: A Symposium, edited by T. R. Hester, pp. 83-90. Special Report 2, Center for Archaeological Research, The University of Texas at San Antonio.

1976b Hunters and Gatherers of the Rio Grande Plain and the Lower Coast of Texas. Non-serial Publication 1, Center for Archaeological Research, The University of Texas at San Antonio.

1977a The Lithic Technology of Mission Indians in Texas and Northeastern Mexico. Lithic Technology IV/1-2. Center for Archaeological Research, The University of Texas at San Antonio.

1977b Material Culture of Missions San Juan Bautista and San Bernardo. In The Archaeology and Ethnohistory of the Gateway Area: Middle-Rio Grande of Texas. Final report to the National Endowment for the Humanities. Assembled by R. E. W. Adams. Photocopy on file at the Center for Archaeological Research, The University of Texas at San Antonio.

1978 Background to the Archaeology of Chaparrosa Ranch, Southern Texas. Special Report 6, Center for Archaeological Research, The University of Texas at San Antonio.

1980 Digging into South Texas Prehistory, A Guide for Amateur Archaeologists. Corona Publishing, San Antonio.

1981 Tradition and Diversity Among the Prehistoric Hunters and Gatherers of Southern Texas. Plains Anthropologist 26(92):119-128.

1985 UTSA Archaeological Field School Excavations in Bandera and Victoria Counties, Texas. Friends of Archaeology Newsletter 2:11-14. Center for Archaeological Research, The University of Texas at San Antonio. 
1989 Historic Native American Populations. In From the Gulf Coast to the Rio Grande: Human Adaptation in Central, South, and Lower Pecos Texas by T. R. Hester, S. L. Black, D. G. Steele, B. W. Olive, A. A. Fox, K. J. Reinhard, and L. C. Bement, pp. 39-62. Arkansas Archeological Survey, Research Series 33.

Hester, T. R., ed.

1976 The Texas Archaic: A Symposium. Special Report 2, Center for Archaeological Research, The University of Texas at San Antonio.

Hester, T. R., F. Asaro, F. Stross. A. C. Kerr, and R. D. Giauque

1991 Trace Element Analysis and Geologic Source Studies of Obsidian Artifacts from Arenosa Shelter, Val Verde County, Texas. In Papers on Lower Pecos Prehistory, edited by S. A. Turpin, pp. 191-198. Studies in Archeology 8, Texas Archeological Research Laboratory, The University of Texas, Austin.

Hester, T. R., D. Gilbow and A. Albee

1973 A Functional Analysis of "Clear Fork" Artifacts from the Rio Grande Plain, Texas. American Antiquity 38:90-96.

Hester, T. R. and J. D. Eaton

1983 Middle-Lower Rio Grande Archaeology. In Borderlands Sourcebook, A Guide to the Literature on Northern Mexico and the American Southwest, edited by E. R. Stoddard, R. L. Nostrand, and J. P. West, pp. 70-74. University of Oklahoma Press, Norman.

Hester, T. R. and T. C. Hill, Jr.

1972 Prehistoric Occupation at the Holdsworth and Stewart Sites on the Rio Grande Plain of Texas. Bulletin of the Texas Archeological Society 43:73-75.

1975 Some Aspects of Late Prehistoric and Protohistoric Archaeology in Southern Texas. Special Report 1. Center for Archaeological Research, The University of Texas at San Antonio.

Hill, T. C., Jr., and T. R. Hester

1971 Isolated Archaic and Late Prehistoric Components at the Honeymoon Site (41ZV34), Southern Texas. Plains Anthropologist 16:52-59.

1973 A Preliminary Report on the Tortuga Flat Site: A Protohistoric Campsite in Southern Texas. Texas Archeology 17(2):10-14.

Hill, T. C., Jr., J. B. Holdsworth and T. R. Hester

1972 Yucca Exploitation: A Contemporary Account from the Rio Grande Plain. In Archaeological Papers Presented to J. W. House (assembled by T. R. Hester), pp. 10-11.

Holdsworth, J.

1972 A Study of Modern Flora and Fauna in the Vicinity of the Holdsworth Site (41ZV14). Bulletin of the Texas Archeological Society 43:65-73. 
Holloway, R. G.

1986 Macrobotanical Analysis of Phase II Materials from the Choke Canyon Reservoir Area, Texas. In The Prehistoric Sites at Choke Canyon Reservoir, Southern Texas: Results of Phase II Archaeological Investigations by G. D. Hall, T. R. Hester, and S. L. Black, pp. 437-451. Choke Canyon Series 10, Center for Archaeological Research, The University of Texas at San Antonio.

Huebner, J. A.

1991 Cactus for Dinner, Again! An Isotopic Analysis of Late Archaic Diet in the Lower Pecos Region of Texas. In Papers on Lower Pecos Prehistory, edited by S. A. Turpin, pp. 175-190. Studies in Archeology 8, Texas Archeological Research Laboratory, The University of Texas, Austin.

Inglis, J. M.

1964 A History of Vegetation on the Rio Grande Plain. Texas Parks and Wildlife Bulletin 45, Austin.

Johnson, E. H.

1931 The Natural Regions of Texas. The University of Texas Bulletin 3113. Bureau of Business Research Monograph 8. Austin.

Krieger, A. D.

1944 The Typological Concept. American Antiquity 9:271-288.

1956 Archeological Typology in Theory and Practice. In: Selected Papers of the Fifth International Congress of Anthropological and Ethnological Sciences, Philadelphia. University of Pennsylvania Press, Philadelphia.

Lintz, C.

1992 Eagle Pass Wastewater Treatment Program. Archeological Planning and Review News \& Views 4 (1). Department of Archeological Planning \& Review, Texas Historical Commission. Austin.

Loomis, L. E., W. J. Gabriel, and B. R. Brasher

1992 Genesis of the Quihi Soil in the Uvalde Gravel of South-Central Texas. In Preliminary Draft of Late Cenozoic Alluvial Stratigraphy and Prehistory of the Inner Gulf Coastal Plain, SouthCentral Texas. Guidebook, 10th Annual Meeting, South-Central Friends of the Pleistocene, March 27-29, 1992. Lubbock Lake Landmark Quaternary Research Center Series 4:47-72. San Antonio.

Lyndon B. Johnson School of Public Affairs

1978 Preserving Texas' Natural Heritage. Lyndon B. Johnson School Policy Research Project Report 31. Austin.

MacNeish, R. S.

1958 Preliminary Archaeological Investigations in the Sierra de Tamaulipas, Mexico. Transactions of the American Philosophical Society 48(6). 
Mallouf, R. J.

1986 Prehistoric Cultures of the Northern Chihuahuan Desert. In Invited Papers from the Second Symposium on Resources of the Chihuahuan Desert Region: United States and Mexico, edited by J. C. Barlow, A. M. Powell and B. N. Timmermann, pp. 69-78. Chihuahuan Desert Research Institute, Allen Press, Lawrence, Kansas.

Marmaduke, W. S.

1978 Prehistoric Culture in Trans-Pecos Texas, an Ecological Explanation. Ph.D. dissertation, The University of Texas, Austin.

McKern, W. C.

1939 The Midwestern Taxonomic Method as an Aid to Archaeological Culture Study. American Antiquity 4:301-313.

Montgomery, J. L.

1978 The Mariposa Site: A Late Prehistoric Site on the Rio Grande Plain of Texas. Special Report 6, Center for Archaeological Research, The University of Texas at San Antonio.

Mueller, J. E.

1983 Geology and Landforms. In Borderlands Sourcebook, A Guide to the Literature on Northern Mexico and the American Southwest, edited by E. R. Stoddard, R. L. Nostrand, and J. P. West, pp. 81-86. University of Oklahoma Press, Norman.

Nance, C. R.

1972 Cultural Evidence for the Altithermal in Texas and Mexico. Southwestern Journal of Anthropology 28:169-192.

Newcomb, W. W., Jr.

1956 A Reappraisal of the 'Cultural Sink' of Texas. Southwestern Journal of Anthropology 12:145153.

1960 The Indian Tribes of Texas. Bulletin of the Texas Archeological Society 29:1-34.

1961 The Indians of Texas from Prehistoric to Modern Times. University of Texas Press, Austin.

Newton, M. B.

1968 The Distribution and Character of Sites, Arroyo Los Olmos, Starr County, Texas. Bulletin of the Texas Archeological Society 38:18-24.

Nunley, J. P.

1975 Report of Archaeological Survey Activities, 1975. In The Archaeology and Ethnohistory of the Gateway Area: Middle-Rio Grande of Texas. Report of the 1975 Investigations. Unpublished manuscript assembled by R. E. W. Adams and submitted to the National Endowment for the Humanities by the University of Texas at San Antonio, December, 1975. Photocopy on file at the Center for Archaeological Research, The University of Texas at San Antonio. 
1977 Concerning the Relationship between the Historic and Aboriginal Populations in the Guerrero Vicinity. In The Archaeology and Ethnohistory of the Gateway Area: Middle-Rio Grande of Texas. Final report to the National Endowment for the Humanities. Assembled by Richard E. W. Adams at The University of Texas at San Antonio. Photocopy on file at the Center for Archaeological Research, The University of Texas at San Antonio.

1989 A Field Guide to Archeological Sites of Texas. Texas Monthly Press. Austin.

Nunley, J. P. and T. R. Hester

1966 Preliminary Archeological Investigations in Dimmit County, Texas. Texas Journal of Science 18(3):233-253.

1975 An Assessment of Archaeological Resources in Portions of Starr County, Texas. Archaeological Survey Report 7. Center for Archaeological Research, The University of Texas at San Antonio.

Peck, J.

1991 An Analysis of the Projectile Points from the 1932 Excavation of Fate Bell Rockshelter. In Papers on Lower Pecos Prehistory, edited by S. A. Turpin, pp. 65-86. Studies in Archeology 8, Texas Archeological Research Laboratory, The University of Texas, Austin.

Perttula, T. K.

1991 Memorandum of Understanding Drafted for the Protection of Cultural Resources in Coal Mines. APR News and Views 3(2):15-16. Department of Archeological Planning and Review, Texas Historical Commission, Austin.

Pine, A. L.

1990 The Texas Middle Corridor: Options for the '90s, Twin Plant News, June, 1990.

Pingenot, B. E.

ca. 1990 Historical Highlights of Eagle Pass and Maverick County, Eagle Pass Chamber of Commerce, Eagle Pass, Texas.

Potter, D. R.

1990 Archaeological Survey of Property for the Proposed Eagle Pass International Bridge, Maverick County, Texas. Archaeological Survey Report 200, Center for Archaeological Research, The University of Texas at San Antonio.

Powell, A. M.

1988 Trees and Shrubs of Trans-Pecos Texas Including Big Bend and Guadalupe Mountains National Parks. Big Bend Natural History Association, Big Bend National Park, Texas.

Powell, A. M., R. R. Hollander, J. C. Barlow, W. B. McGillivray, and D. J. Schmidly, eds.

1990 Papers from the Third Symposium on Resources of the Chihuahuan Desert Region: United States and Mexico. Chihuahuan Desert Research Institute. Printech, Lubbock.

Renfro, H. B., D. E. Feray, and P. B. King

1973 Geological Highway Map of Texas. United States Geological Survey, American Association of Petroleum Geologists, Tulsa. 
Riskind, D. H., and D. D. Diamond

1988 An Introduction to Environments and Vegetation. In Edwards Plateau Vegetation: Plant Ecological Studies in Central Texas edited by B. B. Amos and F. R. Gehlbach, pp. 1-15. Baylor University Press, Waco, Texas.

Ruecking, F., Jr.

1953 The Economic System of the Coahuiltecan Indians of Southern Texas and Northeastern Mexico. Texas Journal of Science 5:480-497.

1955a The Coahuiltecan Indians of Southern Texas and Northeastern Mexico. Unpublished Master's thesis, Department of Anthropology, University of Texas, Austin.

1955b The Social Organization of the Coahuiltecan Indians of Southern Texas and Northeastern Mexico. Texas Journal of Science 7:357-388.

Russell, R. J.

1945 Climates of Texas. Annals, Association of American Geographers 35:37-52.

Salinas, M.

1990 Indians of the Rio Grande Delta: Their Role in the History of Southern Texas and Northeastern Mexico. University of Texas Press, Austin.

Shafer, H. J.

1986 Ancient Texans: Rock Art and Lifeways Along the Lower Pecos. Texas Monthly Press, Austin.

Sjoberg, A. F.

1953 The Culture of the Tonkawa, A Texas Indian Tribe. Texas Journal of Science 5:280-304.

Slade, R. M., Jr.

1986 Large Rainstorms Along the Balcones Escarpment in Central Texas. In The Balcones Escarpment: Geology, Hydrology, Ecology, and Social Development in Central Texas, edited by P. L. Abbott and C. M. Woodruff, Jr., pp. 15-19. Published for the Geological Society of America Annual Meeting, San Antonio, Texas, November, 1986. Printed by Comet Reproduction Service, Santa Fe Springs, California.

Smith, H. M., M. H. Layton, J. T. Miller, T. W. Glassey, and R. M. Marshall

1940 Soil Survey of Zavala County, Texas. United States Department of Agriculture, Bureau of Plant Industry Series 1934, 21.

Sobolik, K. D.

1991 Prehistoric Diet and Subsistence in the Lower Pecos as Reflected in Coprolites from Baker Cave, Val Verde County, Texas. Studies in Archeology 7, Texas Archeological Research Laboratory, The University of Texas, Austin.

Stephens, A. R., and W. M. Holmes

1989 Historical Atlas of Texas. University of Oklahoma Press. Norman. 
Suhm, D. A., and E. B. Jelks eds.

1962 Handbook of Texas Archeology: Type Descriptions. Published jointly as Texas Archeological Society Special Publication 1 and Texas Memorial Museum Bulletin 4. Austin.

Suhm, D. A., E. B. Jelks, and A. D. Krieger

1954 An Introductory Handbook of Texas Archeology. Bulletin of the Texas Archeological Society 25.

Swepston, D. A., and T. L. Hailey

1991 Texas Pronghorns. Federal Aid Report Series 29. Texas Parks and Wildlife Department, Fisheries and Wildlife Division, Austin.

Taylor, W. W.

1972 The Hunter-Gatherer Nomads of Northern Mexico: A Comparison of the Archival and Archaeological Records. World Archaeology 4:167-178.

Texas Historical Commission

1981 Guidelines for Archeological Investigation of Mining Areas in Texas. Texas Historical Commission. Austin.

Thornthwaite, C. W.

1948 An Approach Toward a Rational Classification of Climate. Geographical Review 38:55-94.

Turner, S. E. and T. R. Hester

1985 A Field Guide to Stone Artifacts of Texas Indians. Texas Monthly Press, Austin.

Turpin, S. A.

1991 Time Out of Mind: The Radiocarbon Chronology of the Lower Pecos River Region. In Papers on Lower Pecos Prehistory, edited by S. A. Turpin, pp. 1-49. Studies in Archeology 8, Texas Archeological Research Laboratory, The University of Texas, Austin.

Turpin, S. A., ed.

1991 Papers on Lower Pecos Prehistory. Studies in Archeology 8, Texas Archeological Research Laboratory, The University of Texas, Austin.

U.S. Department of Agriculture

1977 Soil Survey of Maverick County, Texas. United States Department of Agriculture, Soil Conservation Service. In cooperation with Texas Agricultural Experiment Station.

Varner, D. M.

1968 The Nature of Non-buried Archaeological Data: Problems in Northeastern Mexico. Bulletin of the Texas Archeological Society 38:51-65.

Warren, J. E.

1989a A Cultural Resources Survey of the City of San Ygnacio Wastewater Improvement Project, Zapata County, Texas. Archaeology Consultants, George West, Texas.

1989b An Archeological Context for the Lower Rio Grande Laterals Archeological Region of Southern Texas and Northeastern Mexico. Archaeology Consultants, Report 185. George West, Texas. 
Wauer, R. H. and D. H. Riskind eds.

1974 Transactions of the Symposium on the Biological Resources of the Chihuahuan Desert Region: United States and Mexico. National Park Service Transactions and Proceedings Series 3. U.S. Department of the Interior, National Park Service. U.S. Government Printing Office, Washington, D.C.

Weddle, R. S.

1968a San Juan Bautista: Mother of Texas Missions. Southwestern Historical Quarterly 71:542-563.

1968b San Juan Bautista: Gateway to Spanish Texas. University of Texas Press, Austin. 


\title{
APPENDIX I
}

\section{GEOLOGICAL STUDY OF THE DOS REPUBLICAS STRIP MINE}

\author{
David Shahabrook
}

\section{GENERAL GEOLOGY AND GEOMORPHOLOGY}

The strip mine proposed by Dos Republicas Resources Company, Inc., is located along Elm Creek approximately eight kilometers north-northeast of Eagle Pass in Maverick County, Texas. It includes the present floodplain of Elm Creek, the floodplain of an unnamed tributary that flows into Elm Creek from the north, and portions of the surrounding uplands (Figures 1 and 2). The section of Elm Creek within the permit area is approximately $6,000 \mathrm{~m}$ long and the floodplain is about $1,500 \mathrm{~m}$ wide. The permit area averages about $2,500 \mathrm{~m}$ in width, perpendicular to the channel of Elm Creek.

The uplands rise roughly $15-18 \mathrm{~m}$ above the floor of Elm Creek and are composed of Cretaceous age bedrock capped in some areas (particularly north of the creek) with six meters or more of lag gravel deposits. The valley slopes are relatively gentle except in the southeastern portion of the area where there is an $18 \mathrm{~m}$ scarp of Cretaceous bedrock. To the north of Elm Creek there appears to be a remnant of a fluvial terrace or abandoned floodplain surface. The surface is approximately $2-3 \mathrm{~m}$ above that adjacent to the current Elm Creek channel and it slopes gently to the southeast. On both sides of Elm Creek small, intermittent streams have dissected the higher ground in a series of deep narrow valleys that extend basically at right angles from the main valley. The central valley trends roughly northeast to southwest across the permit area. The main channel is presently located along the extreme eastern or southeastern edge of its floodplain in most of the permit area.

The near-surface geology of the permit area consists of sandstones, claystones, coal, and limestones of Upper Cretaceous age that are unconformably overlain by Tertiary and Quaternary sands, silts, gravels, and clays. The Upper Cretaceous units that underlie the floodplain and the higher ground to the north of Elm Creek and form the uplands to the south belong to the Olmos and San Miguel Formations. The Cretaceous units were deposited ca. 75 million years ago (during a transgressive-regressive depositional cycle) in deltaic, fluvial, fluvial backswamp, and shallow marine environments.

The San Miguel Formation, which is approximately $120 \mathrm{~m}$ thick, is composed of sandstones and sandy limestones overlain by claystones that were probably deposited in near-shore and shallow-marine environments, and may underlie a small portion of the northern and northwestern edge of the permit area. The Olmos Formation, which conformably overlies the San Miguel and outcrops south of Elm Creek, underlies the vast majority of the study area. It is $120-150 \mathrm{~m}$ thick and composed of interbedded sandstone and claystone with minor amounts of coal. The Olmos was probably deposited in deltaic, fluvial, and fluvial-related environments and commonly contains ferruginous concretions and silicified wood. This unit weathers rapidly and easily where it is exposed in the southeastern portion of the study area. It forms steep-sided, highly-dissected hills, mantled with deposits of loose, white-to-pale-gray, finegrained sand and abundant, irregular masses of iron concretions.

Structurally, the upper Cretaceous units in the study area are located on the southwestern flank of the large, southeastward-plunging Chittam Anticline. The anticline's axis is marked by the present channel of Mustang Creek. Both the Olmos and the San Miguel locally dip gently to the southeast into the Rio Grande Embayment (the northwestern portion of which is also known as the Maverick Basin). Both formations may have been affected by the northeast-southwest trending faults that are observed in the 
vicinity of the Chittam Field along Mustang and Salado Creeks approximately $10-15 \mathrm{~km}$ to the northeast of the study area. Interestingly, the trend of Elm Creek's valley in the study area is parallel or subparallel to the trend of the aforementioned faults that dissect the Upper Cretaceous units just to the northeast (Barnes 1976). Given the principally fluvial origin of the Olmos and the highly erodible nature of some of its members, considerable lithologic variability is likely within its outcrops and subcrops within the study area. It is probable this variability is also an attribute of the topography of contact between the Olmos and the overlying zones and that it has had a strong influence on sediment characteristics and valley structure for Elm Creek and its feeder streams.

The Tertiary and Quaternary deposits that rest unconformably on the Upper Cretaceous units in the permit area consist of Pliocene-to-Pleistocene-age Uvalde Gravels and Holocene-age sands, silts, gravels, and clays. Although it is possible Pleistocene sediments other than the Uvalde Gravels are present either along the margins of the floodplain or beneath the younger Holocene deposits, none was observed during fieldwork. The Uvalde Gravels dominates the surface of the uplands on the north and west sides of the permit area but is present to a much lesser degree to the south and east of Elm Creek. It is a lag deposit of waterworn gravels that were derived principally from the Cretaceous chert and carbonate units of the Edwards Plateau and the Balcones Fault Zone to the north and from reworking of the coarse fluvial sediments of the younger (Tertiary) Ogallala Formation to the north and west (Byrd 1971:5-7,13-20).

The lag gravels formed a portion of the series of Late Tertiary and Early Quaternary fluvial deposits that blanketed much of the area during the prolonged erosional period subsequent to the uplift of the Southern Rocky Mountains. The fluvial deposits were reworked and the finer fraction was stripped away, leaving the coarse lag gravels that tend to be resistant to further erosion; consequently, the Uvalde Gravels acts as anti-erosional "armor" (Byrd 1971:29), capping many hills and upland surfaces. This is certainly true in the permit area where the upland zones adjoining Elm Creek's valley to the west and north are protected by over $5 \mathrm{~m}$ of Uvalde Gravels and have relatively flat, smooth surfaces. In contrast, the high ground to the east and south that lacks this protection is very irregular and shows signs of ongoing erosion (Barnes 1976; Marston \& Marston 1991a).

Clearly, varying thicknesses of the fluvial-alluvial parent of the Uvalde Gravels were deposited unconformably over the Cretaceous bedrock in much of the permit area. The lag gravel deposits derived from these Pliocene-Pleistocene sediments are now completely absent in the Elm Creek floodplain and are present only as isolated remnants south and east of Elm Creek, but they are still quite prominent on the uplands north and west of the floodplain. Within the latter area, the Uvalde Gravels is slowly being eroded by the headward progression of small streams (A thick gravel bed was observed in backhoe trench [BHT] 13; Figure 31.) and by colluvial and slopewash processes along the edge of the uplands (note the large amount of gravel encountered throughout BHT 15; Figure 32).

As noted elsewhere in this report, the Uvalde Gravels was an important source of raw material for stone tool manufacturing by the ancient inhabitants of the region. It and its derivatives appear to be principally composed of chert, limestone, and quartzite. This contrasts sharply with the gravel deposits found along the Rio Grande that contain higher proportions of cobbles and pebbles derived from igneous and metamorphic sources (U.S. Army Corps of Engineers 1992:3-54). Thus, the Uvalde Gravels in the vicinity of the permit area were derived principally from the Edwards Plateau to the north rather than from the ancestral Rio Grande to the south and west.

Again, the youngest sediments in the permit area are Holocene. They form the surface layer on the entire Elm Creek floodplain and in places they cover the older upland deposits. Their thickness is highly variable throughout the study area and, on the Elm Creek floodplain, ranges from $<1 \mathrm{~m}$ in a cutbank 
This page has been

redacted because it

contains restricted

information. 


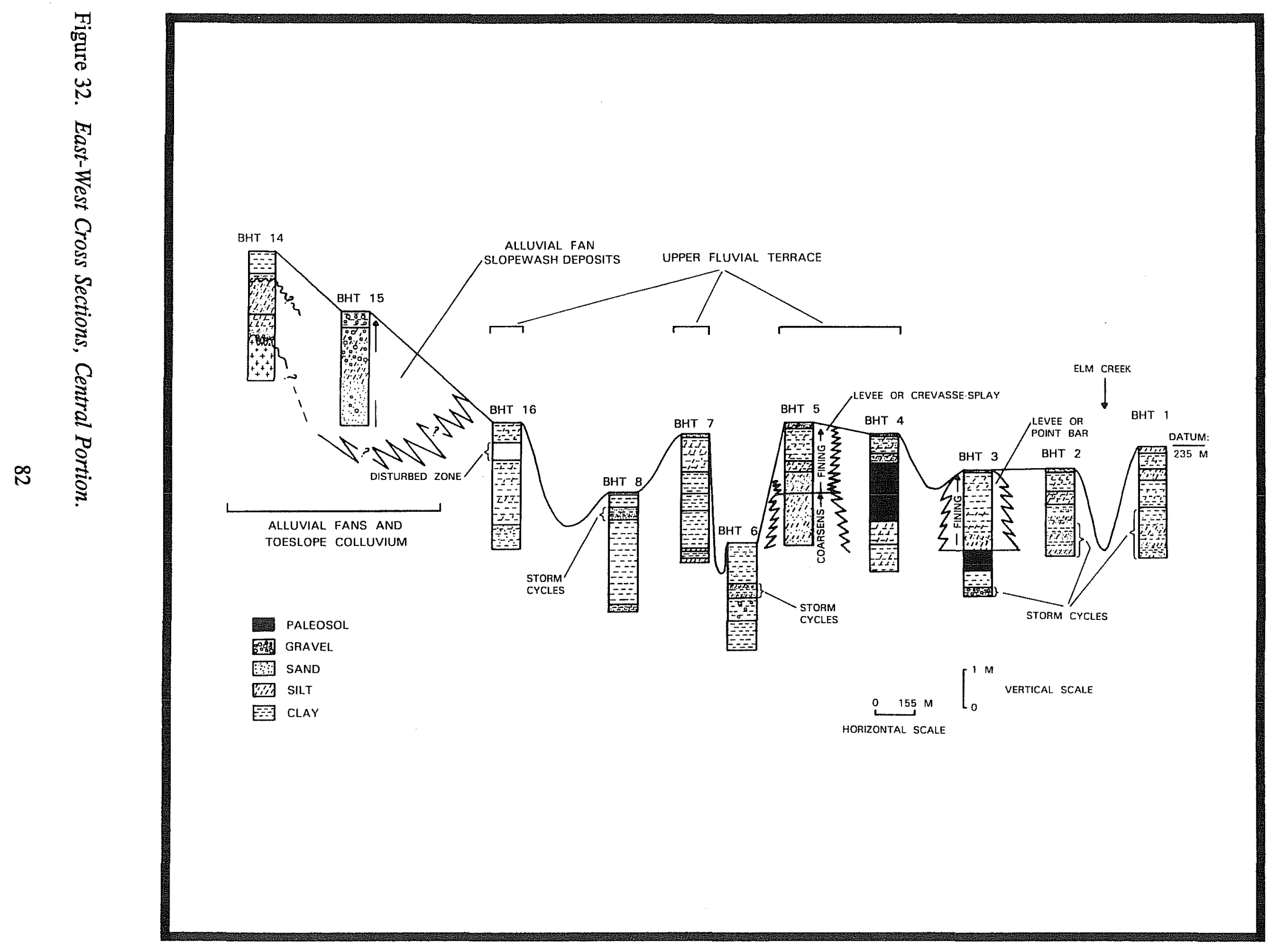


exposure just east of BHT 11, to over eight meters in Core Hole DRRC-91-50 (Marston \& Marston 1991b; Figure 31). Accounting for the facts that Core Hole DRRC-91-50 was drilled from the surface of a lower portion of the floodplain and that the Holocene deposits appear to wedge out in portions of the floodplain margin, their actual thickness probably ranges from 0-10 m.

The Holocene sediments observed (see next section and Appendix II for detailed descriptions) were formed by a variety of processes including colluvial erosion, slopewash, alluvial and fluvial reworking of earlier deposits, and simple weathering or erosion of existing outcrops of Upper Cretaceous and Uvalde Gravels sediments. Erosional downwasting is probably an important factor in the derivation of the Holocene sediments found in the colluvial and slopewash deposits north and west of Elm Creek along the foot of the uplands (e.g., the area around BHTs 14,15; Figures 31,32) and in several other areas, including the many zones of surface sediments which mantle the uplands and the deposits of the small streams that drain the uplands on both sides of Elm Creek. The erosional processes range from in situ development of soil from exposed bedrock by pedogenesis, to weathering followed by increasing transportation of Upper Cretaceous and other unconsolidated sediments by wind and water. The latter were augmented by alluvial and colluvial erosion and slopewash; nevertheless, the bulk of the Holocene sediments were observed on the Elm Creek floodplain were deposited by fluvial processes. More specifically, the near-surface sediments appear to have been formed as a sequence of point-bar, levee, back-swamp, and associated deposits by a relatively sinuous, meandering stream which occasionally switched its channel by the process of avulsion.

Accordingly, the present morphology of the Elm Creek floodplain, especially in the northern portion of the permit area, has also been shaped primarily by the same mechanisms. Particularly noticeable are the abandoned channels or sloughs. Most of these relict channels either contain small oxbow lakes or ponds in low areas, or show signs of recent flooding or other stream action that indicate that they are an active part of the drainage system; for example, piles of wood and other organic debris stacked against the upstream sides of standing trees or absence of leaf-litter and other organic-rich surface deposits. Many of these sloughs have low, sandy rises parallel or subparallel to them that are probably either accretion topography or natural levees.

All of the active stream channels were somewhat entrenched. Water surfaces were 1-2 $\mathrm{m}$ below the level of the surrounding floodplains, a situation that tends to inhibit future avulsion events and the formation of natural levees. Another prominent relict fluvial feature is the abandoned terrace most noticeable north and west of Elm Creek in the vicinity of site 41MV193 (Figure 31). It is roughly 5-6 m above the current floodplain. Whether it is the product of a single depositional event or if it is a patchwork of many ancient floodplain remnants is unknown, but clearly from the backhoe trench data the pattern of sediments present is very similar to those observed elsewhere in the permit area. It is being actively eroded at its margins by Elm Creek and its tributaries and deflated by eolian, alluvial, and sheetwash processes.

Another subtle but important topographic feature of the Elm Creek floodplain in the permit area is the fan of colluvium and slopewash material being built outward from the toe slope of the uplands north and west of the creek onto the surface of the upper fluvial terrace. This deposit has lessened the break in slope between the uplands and the Elm Creek floodplain, and appears to extend for a considerable distance onto the floodplain. There does not seem to be a similar apron of colluvium at the toe slope of the uplands south and east of Elm Creek because the present channel virtually abuts the uplands in this area. Thus, any colluvial or slopewash deposits that might otherwise have accumulated there have been destroyed by fluvial erosion. 
It is also appropriate to note at this juncture that much of the Elm Creek floodplain and its sediments have been greatly modified by humans in historic times. These artificial alterations include the construction of stock ponds along active streams; the building of irrigation canals and pipelines; such agricultural activities as deep root plowing (as evidenced by the disturbed zone in BHT 16; Figure 33), clearing, and construction of large-scale irrigation works (A high level of calcification was observed in the sediments in BHTs 14,15; Figures 32,33); and the building of the Southern Pacific Railroad and of numerous ranch and farm roads in the vicinity. At least in the southern and western portions of the permit area, these activities have so changed the Elm Creek floodplain that it is not possible to make accurate statements about its natural morphology.

\section{FIELD METHODOLOGY}

The geologic studies which are the subject of this report were performed to determine the types, relationships, environments and methods of deposition, and relative ages of near-surface sediments present in the permit area. A major objective was also to gain a detailed understanding of the formation of the Elm Creek floodplain and adjoining uplands that would facilitate the discovery and assessment of surface and subsurface cultural resources in the area. The bulk of the investigation was focused on the northern portion of the area because (1) it appeared to have suffered less disturbance from artificial activities during historic times than the remainder of the area, (2) the topography there appeared favorable for the occurrence of archaeological sites, and (3) the existing roads and fences augmented the excavation of backhoe trenches along two transects oriented normal to the valley axis (Figure 32). Specifically, the objectives of the series of backhoe trenches excavated in the area were:

1. to examine the sediments in two roughly east-west transects across the floodplain and the toe slopes of the adjoining upland areas, to collect data on sediment types and stratigraphic relationships, to construct diagnostic cross sections through the floodplain, and to test for the presence of cultural materials not previously discovered (BHTs 211,14-16; Figure 32);

2. to test three areas where cultural material had been previously found to determine the extent, degree of preservation and stratification of both cultural deposits and natural sediments; and to determine relationships of such deposits to those in other portions of the permit area (BHTs 1, 12,13; Figure 32).

The backhoe trenches (BHTs 1-16) were approximately 4-5 $\mathrm{m}$ long, $60 \mathrm{~cm}$ wide, and ranged from 1.9-3.5 $\mathrm{m}$ deep. Depths were not consistent because of variations in the structural competency of sediments and the height of the water table. In each trench, matrix samples were screened using $1 / 4$ in or $1 / 2$ in mesh hardware cloth, and the screened fraction of cultural material was provenienced and collected. The depth, thickness, and Munsell value (while moist), of each stratum was also recorded in the field. Certain sediment samples were collected for specialized analysis. Elevations for the trenches were estimated from USGS quadrangle maps.

\section{SEDIMENT DESCRIPTIONS}

Sixteen backhoe trenches were excavated in the permit area (Figure 32). A comprehensive profile description for each trench is given in Appendix II. Two cross sections were constructed across the Elm Creek valley, one in the central portion (Figure 33) and one in the northern portion (Figure 34) of the 
This page has been

redacted because it

contains restricted

information. 


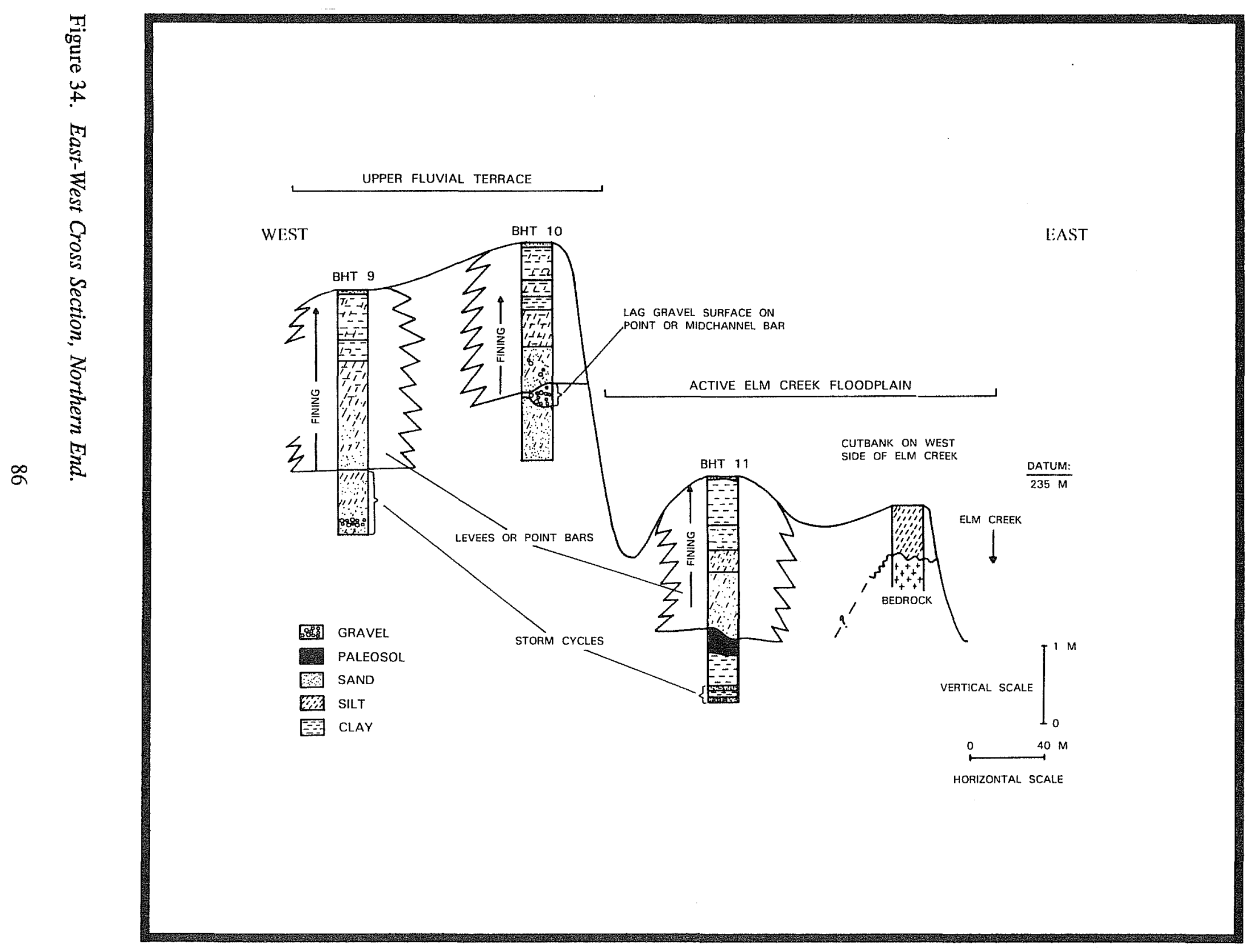


area. With the exception of BHT 14 (which partially penetrated the Upper Cretaceous bedrock), the trenches encountered only Holocene-age sediments.

The sediments appeared to be of two major types: those deposited mainly by fluvial processes (BHTs 113,16); and those formed primarily by alluvial, colluvial, and slopewash processes (BHTs 14,15). The two trenches near the toe slopes at the valley margins contained mostly alluvial and colluvial sediments of upland origins. This interpretation is supported by the elevation and position of the deposits at the lower edge of the uplands and the presence of large gravels dispersed throughout them (particularly in BHT 15).

In BHT 14 the strata are almost certainly colluvial and slopewash deposits, while those in BHT 15 are probably either colluvial and slopewash or alluvial fan sediments deposited by the unnamed stream that drains from the uplands onto the floodplain to the south. They could also be the result of a combination of several such processes. The fining-upwards configuration of the sediments observed in BHT 15 and the presence of considerable numbers of large gravels would tend to favor an alluvial fan origin.

BHT 12, located near the debouch of two small drainages onto the central floodplain at the valley margin, encountered fining-upward sequences which may also be alluvial fan deposits. These two fining-upward sequences are separated by a unit comprised of finely interbedded silts and sands (as related to storm cycles, see below), and unconformably overlie a massive sand body. Thus, they could represent channelmargin-levee or lateral-accretion deposits or even a zone of interfingering between floodplain meander belt sediments and alluvial fans building onto the floodplain.

The soil profiles encountered in BHTs 14 and 15 appear to be relatively young (having A-C type profiles). Given that soil development on or near active floodplains is often slow, there is some possibility these deposits are considerably older than they appear. The apparent lack of soil development in this area could be due to erosional removal of developing soil by the action of sheetwash and slopewash induced by storm runoffs or by the action of the unnamed stream to the south. A good example of the effects of slopewash in retarding soil development would be the prominent stratigraphic break observed in BHT 14 at a depth of $76 \mathrm{~cm}$. At that point, a sandy silt is abruptly truncated by a sandy, silty clay, both of which appear to have undergone considerable pedogenesis.

A youthful appearance is atypical of alluvial fan sediments deposited by streams onto the margins of floodplains. This is because portions of each fan are alternately built and eroded as the stream depositing them changes position within the fan in response to sediment supply, the volume of flowing water, and the topography of the fan. Analogously, it is interesting to note the alluvial fan deposited by the unnamed drainage south of BHT 15 appears to be undergoing considerable erosion based on the present shape of its fan and the incised nature of its channel. This may indicate either the base level of Elm Creek and its small feeder streams is falling with time, or the average volume of water in the aforementioned unnamed tributary is decreasing with time, or some combination thereof.

For numerous reasons the youthful appearance of the soil profiles in this area does not directly imply that the sediments observed are young. The lack of even an incipient B or AC soil horizon in the deposits of BHT 15 (situated in a relatively high, well-drained portion of the floodplain margin) seems to indicate they are no older than Late Holocene and are probably less than 1,000 years old. The strata in BHT 14 is apparently somewhat older but certainly no older than the beginning of the Holocene. The apparent age of these sediments and the potential thickness $(10+\mathrm{m})$ of sediment in the Elm Creek valley present the likelihood there was considerable colluvial, slopewash, and alluvial-fan deposition at or near the valley margins during the Holocene, particularly over the past few thousand years. 
Nevertheless, the dominant depositional process for the bulk of the sediment observed on the floodplain was fluvial. Again, the Elm Creek floodplain in the permit area contains numerous abandoned channels, small oxbow lakes and ponds, remnants of fluvial terraces, and low rises that are either channel-margin levees or accretion topography. The associated sediments ranged from clays and silts to coarse-grained sands and gravels.

Figures 33 and 34 are essentially transverse sections of the upper portion of the floodplain based on data from the backhoe trenches. These sections and the detailed descriptions in Appendix II clearly illustrate the considerable variation in floodplain trench contents even between trenches apparently located on the same topographic feature less than $130 \mathrm{~m}$ apart. The sectional details also support the proposition that coarser and finer sediments have been segregated to a large extent by the depositional process. Almost without exception the trenches contain few (2-5 beds) zones of either gravel, sand, silt, or clay ranging from roughly $40 \mathrm{~cm}$ to over $2 \mathrm{~m}$ in thickness (as opposed to numerous, alternating, thin beds of varying lithology). This is a pattern that would be normal for fluvial deposits of a meandering or anastomosing river in which the coarser clastics, such as sand and gravel, are concentrated in point-bar, levee, and crevasse-splay deposits in or near the meander or channel belt and the finer sediments, such as silt and clay, are concentrated in lacustrine, back-swamp, and overbank flood deposits on the floodplain on either side of the active channel belt (Cant 1982:119-120; Collinson 1978:Chapter 3).

Several of the excavated trenches (BHTs 3, 5, 9-12) show a distinct partial or total fining-upwards sequence. This is especially noticeable in the profiles of BHTs 10 and 11 in which the sediments graded from a fine-grained sand in the lower portion of the trench to a clay at the top, and in which the finingupwards sequence was directly above a noticeable stratigraphic break. In BHT 10 the sequence rested on a lag-gravel deposit filled with decaying organic matter, whereas in BHT 11 the fining-upwards deposits rested abruptly on a partially truncated paleosol.

The fining-upwards sequences in BHTs 10 and 11 may possibly be lateral-accretion, point-bar deposits, or sediments formed in a channel-margin levee which was steadily increasing in height. This concept is supported by their proximity to some (apparently defunct) channels of Elm Creek and by their disconformable relationships to the underlying sediments. Both of these types of deposits would be common to the active channel belt of a sinuous, meandering stream system. The same is probably true for the fining-upwards sequences observed in BHTs 3, 5, 9, and 12 since each of these deposits is located in close proximity to either an active or an abandoned channel of Elm Creek.

The silt-sand body encountered by BHT 5 is unusual in that it first coarsens-upward from the trench base to a depth of approximately $180 \mathrm{~cm}$, then fines-upward from that point. This type of deposit could have been formed by the migration of a stream's active meander belt into this portion of its floodplain, followed by the establishment of a channel-margin levee. Alternately, it could have been formed by the opening and closing of a breach in a stream's channel-margin levee that allowed the development of a large crevasse-splay deposit. Given the thickness of the deposit, the apparent size of the present and ancestral Elm Creek stream channels, and the apparent thickness of the stream's levee and point-bar deposits, the former seems more likely.

Another type of sand-silt-clay deposit present in the excavated trenches was composed of thin, finelyinterbedded, alternating zones which often contained considerable gravel. The zones ranged from approximately $40-130 \mathrm{~cm}$ in thickness, with the finer portions frequently containing considerable amounts of decaying organic matter and the coarser beds often containing varying amounts of small pebbles and gravels. With the exception of those found in BHT 12, these zones of cyclical deposits were encountered 
mainly in trenches located in or near the present or former channels of Elm Creek (BHTs 1-3, 6, 8) or in deposits typical of low-energy floodplain or back-swamp environments (BHTs 9, 11).

Although the environment of deposition (low-energy portions of the floodplain: back swamps, abandoned channels, or sloughs) seems consistent in each case, several sedimentary processes could have produced the observed deposits. These include small-scale crevasse-splays, alluvial sheetwash (notably flooding episodes), or a combination of eolian and fluvial processes. The narrow width of Elm Creek and the lack of substantial channel-margin levees could easily lead to large-scale sheet floods during periods of heavy precipitation or peak water flow as sediment-laden water filled the channel and spilled onto the adjoining floodplain. Sheet floods of this nature could be responsible for the thin, rhythmically-bedded deposits observed (cf. Cant 1982:123,126). Similarly, small gaps in the channel-margin levee could also have led to the cyclical formation of these sediments as small flows of water from the stream's main channel periodically deposited fine beds of coarser clastics in the low-energy portions of the floodplain.

If the present Elm Creek floodplain surface (in the zones of little artificial disturbance) is any indication of past conditions, then eolian and alluvial sheetwash processes could also have been important factors in producing the stratigraphy found. The layer of loose sand and silt (ca. five centimeters thick) that presently blankets the entire floodplain could quite readily have been blown or washed from higher areas into lows such as oxbow lakes, ponds, abandoned channels, or similar features. If there is a common theme to all of these depositional processes, it is that of routine sedimentation in the lower energy portions of the stream system being occasionally disrupted by influxes of coarser materials during periods of flooding or wind and rainstorms.

Although this type of storm cycle deposit would not seem unusual for an active floodplain, the relatively large quantity of these deposits preserved in a floodplain the size of Elm Creek's does seem atypical. Minimally, this may indicate one or a combination of two things: (1) the large gap between the average and peak discharge rate of Elm Creek that is observed today has existed for a considerable period of time; (2) the volume of sediment available from periodic floods for transport by the present channel or by ancestral channels of Elm Creek has exceeded the carrying capacity of the water volume available for an extended period of time.

The remaining sediments penetrated by the trenches on the floodplain were clays and silts (some of which also contained a portion of sand). These units were predominantly gray, greenish-gray, or grayish-brown and showed evidence of frequent periodic wetting or prolonged water saturation (oxidized zones, concretions, and common mottling). Evidence of periodic hiatuses or diastems in sedimentation and of shifts in the source and type of sediment such as the sharp stratigraphic breaks is found in BHTs 3, 10, and 11. All these factors (very fine grain size, frequent wetting, breaks in sedimentation, inclusion of decaying organic material, presence of storm cycle deposits) indicate these clayey and silty units were laid down in a fluvial-backswamp or overbank depositional environment, or in abandoned channels and oxbow lakes. Again, these slightly sandy silts and clays probably represent deposition during periodic flooding and by accumulation of wind-blown silt and clay particles in topographic lows or standing bodies of water. Some of these sediments may have been carried onto the floodplain by the small streams that drain onto it from the surrounding higher ground and later reworked by floodwaters.

The relationship of the sandy and clayey facies, as well as some of the other sediment types detailed above in the northern and central portions of the permit area, are shown in Figures 32 and 34 . The soil profiles are all poorly to very poorly developed, and range from A-B-C or A-AC-C on the highest, bestdrained portions of the sandy floodplain deposits to A-C or AC-C in many of the lower lying portions of the floodplain. Based strictly on the apparent age of the soil profiles, the oldest of the sediments 
encountered (BHT 7 with the A-B-C profile) is probably no older than 1,000 to 2,000 years, and certainly none would predate the beginning of the Late Holocene (ca. 3,500 B.P.). This lack of pedogenic development may be due to the relatively recent age of the deposits.

Soil development may also have been severely retarded by other factors: the constant wetting and poor drainage common to an active floodplain; the frequent, periodic erosion and removal of the organic-rich upper members of the soil ( $\mathrm{O}, \mathrm{A}$, and $\mathrm{B}$ horizons) via flooding, wind, and stream action; and the periodic deposition of fresh alluvium on portions of the existing surface. The effects of erosional scouring and poor drainage are particularly pronounced in the sloughs and other topographic lows. There is nearly a total absence of leaf litter and other organic debris in these areas despite the proximity of tree cover and other vegetation.

The action of water as a wetting agent and as an erosional mechanism would be enhanced by the effects of the bioturbation noted in many of the trench profiles. Such perturbation would make sediments more subject to erosion and increase the lateral and vertical permeability of the soil. Periodic wetting in this area of calcium-rich soils with relatively abundant ground water would tend to be detrimental to soil formation by promoting the formation of calcareous cements in the sediments. It would also retard pedogenesis by reducing permeability and slowing the leaching of organic materials and clays from the surface.

Presently, given the numerous abandoned stream channels within the floodplain and the fact that a large portion of the alluvium is less than three meters above the normal level of Elm Creek, even a modest rise in the creek level would expose the vast majority of the floodplain's sediments to inundation by floodwaters, a raised water table, or both. Again, much of the surface of the floodplain is blanketed by a $3-5 \mathrm{~cm}$ thick layer of loose silt and sand. This seems to indicate the near-surface of the floodplain is being covered in fresh accumulations of material, principally silt and sand, deposited by the action of wind and water. Whether this fresh sediment represents material brought in from outside the permit area or merely a reworking of deposits already present is unknown.

Given the abundant amount of cultural material present either at or near the surface and the lack of soil development within the permit area, the surface sediment layer likely represents ongoing deflation and erosion of the floodplain. This view is reinforced by the presence of the many small rills and gullies present at the margins of every topographic high point within the study area. The youthful appearance of the sediment profiles could be due to many things other than the age of the deposits being very recent. The surface of the floodplain in many areas is littered with cultural debris dating to periods throughout the Holocene.

These prehistoric artifacts would normally be associated with cultural sites of Late Holocene age $(<3,500$ B.P.), but artifacts associated with cultures of Middle Holocene age (7,000-3,500 B.P.) and even a few associated with cultures of Early Holocene age (10,000-7,000 B.P.) are found. Either the related portions of the present Elm Creek floodplain have existed essentially in their present forms since at least the start of the Late Holocene, or they were being deposited during the Holocene and cultural material contemporaneous with sedimentation have been exhumed by erosion. Depending on whether the cultural material was originally deposited in an aggrading floodplain or on a pre-existing stable floodplain surface, the youthful appearance of the soils could result in serious underestimation of their age. If the floodplain was aggrading throughout the bulk of the Holocene prior to the onset of erosion in the Late Holocene, then the apparent age of the soils is much too young. Conversely, if the present floodplain surface was basically established in the early portion of the Late Holocene, then the apparent age of the soils would not be much different from the actual age. 
The existence of a stable floodplain surface dating to the start of the Late Holocene would imply there was no net sedimentation in the area for a considerable period of time. This means the effective rate of sedimentation and erosion have remained virtually equal. Thus, it seems reasonable to conclude that virtually none of the sediment observed on the floodplain pre-dates the beginning of the Holocene. The available data is insufficient to determine how much of the sediment present in the permit area is younger than the start of the Late Holocene and how much dates to earlier periods of the Holocene.

\section{DISCUSSION}

From the data obtained during the 1992 investigations and comparative information from similar regional studies, the geologic history of the permit area from the Upper Cretaceous to the present may be interpreted as follows.

In the Upper Cretaceous, the Olmos and San Miguel Formations were deposited in fluvial, deltaic, nearshore, and shallow marine environments near the western edge of the Rio Grande Embayment. Other Cretaceous and Lower Tertiary units may have been deposited on top of these two formations, but apparently no trace of such units now remains. Later, these units were folded and possibly faulted to form the southwestern flank of the southeasterly-plunging Chittam Anticline. After this period of structural deformation, considerable erosional sculpting of these units took place prior to the deposition of fluvial sediments in the Upper Tertiary and Pleistocene.

Based on the composition of the remaining lag gravels, the principal source of these units appears to have been to the north across the Balcones Fault Zone. These fluvial units were then subjected to extensive erosional reworking that produced the lag-gravel deposits known as the Uvalde Gravels. The latter probably once covered much of the permit area. Further erosion during the Quaternary reduced the size of this lag gravel deposit in the permit area, leaving it as a cap on the uplands north and west of Elm Creek and as small erosional remnants south and east of the creek.

Other than the deposition of the sediments that would be reworked to form the Uvalde Gravels, the geologic history of the permit area in the Pleistocene is virtually unknown. Interpolating from the geologic histories of other areas in the general region, the permit area likely experienced alternating periods of erosion and sedimentation as the waxing and waning of the Pleistocene glaciations caused variations in sea level and regional climatic conditions. In that case there would have been corresponding changes in the base levels of streams and in average rainfall and temperature within the permit area.

It is reasonable to believe that at some point in the Pleistocene, the ancestral Elm Creek penetrated the armor of the Uvalde Gravels and began carving a valley into the less resistant Upper Cretaceous bedrock. This valley would then have been alternately downcut and aggraded as the climate varied between warmdry and cool-wet periods. Comparative regional data indicate as the final stage of the Pleistocene began, the climate was becoming warmer and drier (Bryant and Shafer 1977; Hester et al. 1989; Patton and Dibble 1982). This would have led to increased rates of erosion, downcutting and widening of the ancestral Elm Creek valley, and to destruction of virtually all of the existing Quaternary sediments in the valley.

If any Pleistocene deposits exist within the Elm Creek valley permit area, they will be found either in the deeper portions of the valley under the present fill, at the margins of the valley under later Quaternary deposits, or as small erosional remnants scattered across the floodplain (generally analogous to the Cretaceous bedrock outlier exposed in the cutbank of Elm Creek east of BHT 11). It is most likely that 
very little Pleistocene-age sediment remains in the Elm Creek valley and apparently none has been positively identified in the permit area.

During the Holocene, the Elm Creek valley was filled with as much as eight meters of sediment in places. The floodplain aggradation was largely accomplished by a sinuous, meandering stream that changed its position on the floodplain periodically by the process of avulsion. This infilling was aided by sedimentation in alluvial fans built at the valley margins, by small tributaries of the present and ancestral Elm Creek, and by the deposition of colluvial and slopewash material at the upland-margin toe slopes.

At least two general aspects of the present floodplain indicate that Elm Creek has avulsed periodically: (1) the number of abandoned channels and sloughs present, and (2) the nearly ubiquitous presence of about three meters of Holocene-age fluvial sediment. When tested, the uppermost portion of the floodplain was found to have been thoroughly reworked. From another perspective, evidence for such avulsions consists of the sharp clay-to-sand-silt transitions seen in BHTs 3, 4, and 11; the presence of fining-upwards sequences in BHTs 3, 5, and 9-12 that appear to be lateral accretions (such as occur in point-bars) or channel-margin levee deposits; and the current style of Elm Creek--a sinuous, narrow channel with steep cut banks. These are all trademarks of an avulsing, meandering stream (Cant 1982:115-116, 119-120, 127, 130; Collinson 1978:32-38; McGowen and Garner 1975:4-9).

The deposits of the ancestral Elm Creek differ from those of a typical anastomosing river or stream in at least three significant ways: (1) the levee or point-bar (sand and gravel) and backswamp-overbank (clay) facies move markedly with depth (time), while those of anastomosing rivers stack vertically for prolonged periods of time--over 6,600 years in some cases (Cant 1982:120; Figures 32,34); (2) there are insufficient levels of organic materials and peat deposits in the Elm Creek backswamp sediments; and (3) widely dispersed (laterally) fining-upwards sequences and gravel deposits are present in the Elm Creek sediments (cf. Cant 1982:120-121, 128-129). Also, within the portion of the Elm Creek system examined, the ratio of sand to clay is too low and the amount of preserved levee and overbank-floodplain sediment is too great to have been produced by a braided or low-sinuosity stream situation (Collinson 1978:38,53).

Interestingly, Elm Creek currently appears to be entrenching itself on the southeastern side of its floodplain, which most likely means that it has probably not avulsed in the recent past. This view is supported by the presence of prehistoric archaeological sites over virtually the entire floodplain surface and in close proximity to the channel as well. If the creek had avulsed recently, then at least some portion of the floodplain surface would be devoid of sites. Any sites located in the path of avulsion would have been quickly and perhaps deeply buried or destroyed.

Although it was possible to determine the nature of some portions of the Holocene-age valley-fill sediments and describe the type of fluvial system which deposited them, it was not possible to precisely determine the sequence of depositional and erosional events that produced the present Elm Creek floodplain. The evolution of the fluvial landscape may have followed at least two logical routes: (1) the valley was first downcut to bedrock, then filled nearly to its current level by the end of the Early Holocene, and then the height of the floodplain remained relatively static throughout the Holocene; or (2) the valley was downcut to bedrock, filled to slightly above its current level by the end of the Early Holocene, downcut again during the Middle Holocene, filled to roughly its present level at the beginning of the Late Holocene, and then eroded to its present shape. Of these, the second scenario or a slight variant of it is the most viable, but the existing evidence is not firm enough to support it or any other sequence of events. 
Three lines of evidence tend to support the geological history proposed for the Elm Creek floodplain in the Holocene. The first concerns paleoenvironmental data gathered from sites near Lake Amistad Reservoir to the northwest of the permit area (Bryant and Holloway 1985; Patton and Dibble 1982), from sites to the north and west in the Llano Estacado (Bryant and Shafer 1977), and from south Texas (Hester et al. 1989). Pertinent references indicate more mesic conditions probably prevailed during the Late Pleistocene and Early Holocene.

Assuming the accuracy of the latter, the ancestral Elm Creek would probably have begun to aggrade its valley at that time. Such elements as depth of valley fill, style of fluvial system, and nature of the sedimentary deposits are presently unknown. After this period of wet, moderate conditions, the climate became drier and hotter. The hot and dry conditions that coincided roughly with the Middle Holocene caused increased rates of erosion and an extended period of fluvial downcutting and destruction of sediments throughout much of the region north of the permit area. This is well documented in Abbott (1990:56-57), Cliff et al. (1992:Chapter 7), and Holliday (1989).

Conditions within the permit area were probably similar to those in the surrounding regions, meaning that during the Middle Holocene, the ancestral Elm Creek would have been vigorously downcutting its valley and that the surrounding uplands would have been subjected to catastrophic downwasting. The paleoenvironmental data indicate a more moist and temperate climatic regime began at the inception of the Late Holocene. This change probably led to rapid alluviation and floodplain aggradation during the first half of the Late Holocene (ca. 4,000-2,000 B.P.). The evidence indicates that since that time the region's climate has gradually become drier and hotter, causing the Elm Creek floodplain to cease aggrading and begin deflating as the balance between sediment accumulation and removal slowly changed from a situation of net deposition to one of net erosion. Erosion persists today as Elm Creek slowly entrenches its channel in the floodplain, and its tributaries dissect the surrounding uplands and then cut channels across the floodplain margins.

The second line of evidence concerning the proposed sequence is the degree of development of soil profiles observed in the backhoe trenches and the topography of the floodplain itself. Again, the soils observed in the trench profiles appear quite youthful. This means either all the sediments encountered are relatively young (not older than the start of the Late Holocene) or those sediments that pre-date the beginning of the Late Holocene have been altered by various factors (previously described herein) so that their actual age has been obscured.

Although it is possible for sediments of substantially different ages to coexist on a single floodplain surface in close proximity (as in the Sulphur River floodplain in the White Oak Management Area; cf. Cliff and Peters, eds. 1991:Chapter 6), the situation rarely occurs. Considering the three possible geomorphological states of floodplains, i.e., aggradation, stability, and erosion, it seems that no permutation of them is likely to produce young-looking deposits that are actually old situated on a floodplain with the given topography. Aggradation would bury the older deposits. A floodplain deposited by an avulsing stream would contain sediments of mixed ages, but the floodplain's stability would have allowed pedogenesis to take place, particularly on the more elevated portions.

The upper portions of the Elm Creek floodplain exhibit a higher level of soil development than the lower portions, but the disparity is probably too small to indicate any great age range between sediments in the two elevational zones. Though erosion can mask the actual age of sediments by stripping away the upper portion of the soil profile, it generally does not operate with equal intensity on all portions of the floodplain at all times. Thus, it is normal for outliers of older material to be left behind as topographic highs as erosional downcutting proceeds. 
Since the topographic highs on the Elm Creek floodplain appear only slightly older than the surrounding sediments, this too would fail to produce a floodplain of the type observed (with approximately six meters of relief, youthful-appearing sediments, and topographic highs with only slightly greater soil development). The only viable explanation is considerable aggradation occurred in an earlier part of the Late Holocene, followed by the onset of floodplain deflation and erosion near the terminus of the Late Holocene. In that case, with few exceptions older deposits would have been buried beneath a wedge of Late Holocene material too thick to have been completely removed by erosion. The Late Holocene erosion would produce the current floodplain topography but would only allow enough time for the floodplain's topographic highs to undergo a modest amount of pedogenesis.

This scenario dovetails with the sequence of events postulated from the paleoenvironmental data. However, it is also possible that one or more of the paleosols encountered in BHTs 3, 4, and 11 could represent pre-Late Holocene floodplain surfaces (a possibility that could probably be affirmed or denied by radiocarbon dating of soil humates present in the paleosols, assuming such dating is otherwise feasible). Although this would still mean that the entire present surface of the floodplain is Late Holocene in age, it would substantially reduce the thickness of Late Holocene sediment present and greatly enhance the possibility that significant amounts of Early Holocene or Middle Holocene deposits are preserved in the valley fill.

The last line of evidence for the proposed sequence is the distinctive juxtaposition of the considerable amount of Holocene-age cultural material encountered during pedestrian archaeological surveys of the permit area. Cultural debris was confined mostly to the surface or within the upper few centimeters over the entire floodplain, and very little was found buried at any substantial depth in the floodplain sediments (the most notable exception being a few pieces of fire-cracked rock in BHT 11). Thus, the cultural material must have been deposited on a relatively stable, non-aggrading surface no longer subjected to periodic avulsions by Elm Creek. Again, the fact that sites are found on the entire floodplain surface implies Elm Creek has been pinned down in its current meander belt and unable to avulse for some period of time, or that erosion on the floodplain is so prevalent that sites are being uncovered faster than they can be buried or destroyed. Given the fact that no substantial buried sites were encountered on the floodplain and the entrenched nature of the current Elm Creek channel, the former situation seems more likely than the latter.

It is difficult to determine when the aforementioned stable surface was established. In correlating geologic with cultural periods and diagnostic artifacts found in the permit area, most of the artifacts recovered seem to date to periods within the Late Holocene. This could imply that the floodplain aggraded to roughly its present level in the early portion of the Late Holocene and has subsequently been undergoing slow deflation and erosion. If correct, this construction would support the proposed sequence of geologic events; however, diagnostic artifacts that date to cultural periods prior to the Late Holocene were found in at least six different sites on the floodplain. If the floodplain surface is indeed Late Holocene in age, these artifacts must be either heirlooms or talismans in use long after their time of origin, or cultural material eroded from earlier sites and later redeposited on the floodplain surface.

Although the presence of small amounts of temporally anomalous cultural material on an active floodplain, due to the action of natural processes or ancient peoples, is not unknown (cf. Cliff and Peter 1991:137-143), the occurrence of such material at six proximate localities is not viably explainable by such mechanisms. An alternative explanation for the presence of these artifacts is that the floodplain surface has been stable since the beginning of the Middle Holocene (ca. 7,000 B.P.). This potential solution appears to be even less attractive geologically since the level of soil development of the sediments on which these artifacts rest is much less than what would be expected if they were Early Holocene in 
age. Such an explanation also requires that the geologic responses to the varying climatic conditions of the Holocene within the permit area contradict those observed at all other localities which have been studied in detail in this region. Although these explanations appear to be mutually contradictory, the resultant dilemma could be conclusively resolved by obtaining radiocarbon dates from either the paleosol humates or from a series of in situ cultural deposits.

Thus, the geological history of the Elm Creek floodplain in the permit area during the Holocene is presently not well known. Although Holocene-age sediments were encountered during the 1992 fieldwork, the assignment of these deposits to various periods within the Holocene would be conjectural. The near-surface of the floodplain is dominated by fluvial and alluvial deposits that are probably of Late Holocene age. During this period, Elm Creek appears to have been a sinuous, meandering stream that avulsed frequently, reworking much of the surface of the floodplain in the process. Several remnants of Early and Middle Holocene or even very late Pleistocene deposits could be buried (and therefore have no surficial topographic expression) beneath younger sediments.

Given the highly variable (nearly random) pattern which the process of channel avulsion would make over an extended period of time, potential for the existence of buried surfaces at almost any location under the present floodplain surface exists. Considering such elements as the width of the Elm Creek floodplain and the relatively limited thickness of the Holocene sedimentary component (10 m maximum), the probability of finding preserved surfaces at moderate depths is greatest at the valley margins or in the higher portions of the floodplain. Presently, insufficient information is available to predict the most probable locations and depths of the various ages of sediments in the floodplain, but most of the valley fill is likely of Late Holocene age and none pre-dates the terminal Pleistocene.

\section{SUMMARY AND ARCHAEOLOGICAL IMPLICATIONS}

The post-Upper Cretaceous geologic history of the Dos Republicas permit area can be summarized as follows. During the Upper Cretaceous, the Olmos and San Miguel Formations were deposited and then structurally deformed, exposed, and eroded. Late Tertiary and Early Pleistocene fluvial sediments were subsequently deposited unconformably on the Cretaceous bedrock. They were reworked to form the lag deposits known as Uvalde Gravels which covered much of the area. At some point in the Quaternary, continued erosion by the ancestral Elm Creek cut through the resistant Uvalde Gravels zone and began to carve a valley into the underlying, relatively less resistant units of the Cretaceous.

In the permit area, this valley eventually reached a depth of roughly 50-60 m and a width of $1.5 \mathrm{~km}$. Pleistocene fluvial or alluvial sediments were possibly deposited in this valley; although some may still be present beneath Holocene sediments, none was observed. The valley was filled during the course of the Holocene with fluvial and alluvial deposits of a sinuous, meandering stream that periodically shifted its channel through the process of avulsion. The valley was also filled by the action of small streams emptying onto the floodplain (forming alluvial fans near the upland margin) and by the building of colluvial and slopewash deposits at the toe slopes of the uplands.

Although the exact sequence of Holocene events is unknown, floodplain aggradation likely commenced early. Following a period of erosion in the Middle Holocene, alluviation resumed for a short period in the Late Holocene. Erosion, floodplain deflation, and destruction of fluvial and alluvial deposits resumed in the middle of the Late Holocene and continued to the present. The presence of Archaic-period cultural material on most of the Elm Creek floodplain clearly indicates there has been no net deposition of sediment in much of the permit area since at least the early portion of the Late Holocene (ca. 2,500-3,000 
B.P.) or possibly earlier. The last period of erosional activity produced a relatively rugged floodplain with a moderately entrenched stream channel and roughly six meters of topographic relief between the present Elm Creek channel and the top of the upper fluvial terrace.

The depositional history of the vicinity has a number of important implications for the location and preservation of cultural resource sites within the permit area. The sandy nature of many of the floodplain deposits, the presence of a constant water source, ready access to higher ground both within and adjacent to the floodplain, and the availability of abundant lithic resources would have made this portion of the Elm Creek valley a very favored habitation zone. If the Holocene geologic history of the permit area proposed herein is correct, any sites located on the floodplain in the Early Holocene would likely have been buried and sealed by later sedimentation. Although many of these sites would have been exhumed and destroyed by erosional processes during the Middle Holocene, some may have survived to be reburied by Late Holocene deposits. Thus, there is a slight possibility that buried, stratified cultural deposits of Early Holocene age exist somewhere on the floodplain.

Because of the erosional nature of the floodplain during the Middle Holocene, few cultural deposits from that time would likely remain intact. Nevertheless, some may have survived long enough to be buried by Late Holocene sedimentation. The Late Holocene apparently ushered in the return of floodplain aggradation followed by a period of relative stability in which there was gradual but steady erosion of floodplain deposits. Assuming the latter, a significant probability of finding prehistoric archaeological sites of early Late Holocene age buried at various depths in the floodplain exists. Such sites would have been only slightly buried prior to the onset of erosion, and sites dating after approximately the middle of the Late Holocene would only rarely have been buried (mostly on stable but slowly deflating surfaces).

Again, this sequence of events correlates well with the available data. It accounts for the surface or nearsurface nature of most of the prehistoric archaeological sites present in the area and the multicomponent character of sites (which would have remained available for later re-use) occupied after ca. 3,000 B.P. It is also possible some or all of the current floodplain surface is older than the Late Holocene, which would slightly increase the possibility of the existence of buried cultural sites on the floodplain. It would also help account for sites (such as 41MV186 and 41MV189) which yield diagnostic artifacts from and prior to the Late Holocene since some portions of the floodplain surface would then have been available for repeated occupation.

Thus, it is logical that although many of the prehistoric cultural manifestations located on the Elm Creek floodplain are surface or near-surface phenomena, diagnostic artifacts affirm that they are multicomponent in character. The latter probably greatly outnumber buried, stratified sites which would be difficult to locate given the lack of surface expression and potential depth of burial. Indeed, the alluvial fan and colluvial-slopewash deposits at the valley margins may offer the most potential for buried cultural deposits since active sediment deposition may have continued in these areas after erosion had already begun on the floodplain. It is indeed noteworthy that the one prehistoric cultural site of apparent archaeological significance is buried to an appreciable extent along the unnamed tributary of Elm Creek on the northwestern side of the permit area.

The major conclusions regarding the prehistoric archaeology of the Dos Republicas permit area are: (1) some potential for the presence of buried, sealed, stratified cultural sites of Holocene age within the area exists, but these sites may be few in number, difficult to find, and buried to a considerable depth; and (2) apparently there are several large, single component and multicomponent surface sites that are easily located and could be worthy of further investigation in some instances. 
The primary conclusion regarding the recent geologic history of the Dos Republicas permit area is that it can logically be divided into three phases: (1) deposition, weathering, and erosional sculpting of the Upper Cretaceous Olmos and San Miguel Formations; (2) deposition, weathering, and erosion of Pliocene and Pleistocene fluvial sediments that produced the Uvalde Gravels; and (3) Pleistocene downcutting and Holocene infilling of the ancestral Elm Creek valley. In its later phases the infilling was accomplished by a sinuous, meandering stream and its small tributaries, alluvial fans built by small intermittent drainages, and colluvial-slopewash deposits. 


\section{REFERENCES CITED}

Abbott, J. T.

1990 Geomorphic and Geoarcheological Investigations. In Phase II Investigations at Prehistoric and Rock Art Sites, Justiceburg Reservoir, Garza and Kent Counties, Texas, Report of Investigations 7, volume I, by D. K. Boyd, J. T. Abbott, W. A. Bryan, C. M. Garvey, S. A. Tomka, and R. C. Fields, pp. 23-62. Prewitt \& Associates, Austin.

Barnes, V. E.

1976 Geologic Atlas of Texas: Crystal City-Eagle Pass Sheet. Bureau of Economic Geology, The University of Texas, Austin.

Bryant, V. M., Jr. and R. G. Holloway

1985 A Late Quaternary Paleoenvironmental Record of Texas: An Overview of the Pollen Evidence. In Pollen Records of Late Quaternary North American Sediments, pp. 39-70. American Association of Stratigraphic Palynologists Foundation, Dallas.

Bryant, V. M., Jr. and H. J. Shafer

1977 The Late Quaternary Paleoenvironment of Texas: A Model for the Archeologist. Bulletin of the Texas Archeological Society 48:1-25.

Byrd, C. L.

1971 Origin and History of the Uvalde Gravel of Central Texas. Baylor Geological Studies 20. Baylor University, Waco, Texas.

Cant, D. J.

1982 Fluvial Facies Models. In Sandstone Depositional Environments, ed. by P. A. Scholle and D. Spearing, pp. 115-138. American Association of Petroleum Geologists, Tulsa.

Cliff, M. B. and D. E. Peter

1991 Cultural Resources Survey of Remaining Areas of the Louisiana Army Ammunition Plant, Webster Parish, Louisiana, LAAP Archaeological Technical Series Report of Investigations 4, Geo-Marine, Plano, Texas.

Cliff, M. B. and D. E. Peter (editors)

1991 Cultural Resources Survey of the Moist Soils Management Area, White Oak Creek Mitigation Area (WOCMA), Cass County, Texas. Miscellaneous Report of Investigations 26, Geo-Marine, Plano, Texas.

Cliff, M. B., D. S. Shanabrook, S. M. Hunt, and S. N. Allday

1992 Testing and Evaluation of Archaeological Sites in the Vicinity of the Lowrance Pumping Station, Area X, Red River Chloride Control Project, King County, Texas. Miscellaneous Report of Investigations 37, Geo-Marine, Plano, Texas.

Collinson, J. D.

1978 Alluvial Sediments. In Sedimentary Environments and Facies, ed. by H. G. Reading, pp 15-60. Elservier, New York. 
Hester, T. R., S. L. Black, D. G. Steele, B. W. Olive, A. A. Fox, K. J. Reinhard, and L. C. Bement 1989 From the Gulf Coast to the Rio Grande: Human Adaptation in Central, South, and Lower Pecos, Texas. Arkansas Archeological Survey Research Series 33, Fayetteville.

Holliday, V. T.

1989 Middle Holocene Drought on the Southern High Plains. Quaternary Research 31:74-82.

Marston \& Marston, Inc.

1991a Sample Description and Core Description. Hole \#DRRC-91-58: overburden core hole. Marston \& Marston, St. Louis.

1991b Sample Description and Core Description. Hole \#DRRC-91-50: overburden core hole. Marston \& Marston, St. Louis.

McGowen, J. H. and L. E. Garner

1975 Physiographic Features and Stratification Types of Coarse-Grained Point Bars: Modern and Ancient Examples. Bureau of Economic Geology, The University of Texas at Austin, Geological Circular 75-9.

Patton, P. C. and D. S. Dibble

1982 Archaeological and Geomorphic Evidence for the Paleohydrologic Record of the Pecos River in West Texas. American Journal of Science 282:97-12.

U.S. Army Corps of Engineers

1992 The Final Environmental Impact Statement for the Del Rio Border Station Expansion, Del Rio, Texas. Fort Worth District. 


\section{APPENDIX II}

\section{BACKHOE TRENCH PROFILE ANALYSIS}

\section{David Shanabrook}

Note: The sections are arranged with brief general data (locations, elevations, associations) at the beginning, followed by descriptions of the strata observed in each trench. In the strata descriptions, the depths below the surface are expressed at the left in centimeters, followed by the soil zone types (standard alphanumeric designations) and qualitative summaries of soil attributes (matrix composition, color, texture, Munsell value, and natural and cultural inclusions).

\section{BACKHOE TRENCH 1}

Location: north end of site 41MV192; elevation: $235.0 \mathrm{~m}$

0-17 A Very dark, grayish-brown to dark brown (10YR $3 / 2$ to $3 / 3$ dry), silty clay with trace sand; friable; blocky; gradual to diffuse boundary; scatter of cultural material at surface

17-55 C1 Brown (10YR 5/3) slightly silty clay; strong blocky; firm; few pieces of charcoal; dark decay stain; fine krotovina filled with material from overlying zone; clear to abrupt boundary

55-82 C2k Brown (10YR 5/3) fine sandy silt; blocky; very firm to dense; few white, soft calcareous concretions; zone heavily calcified; few open rootlet holes with calcareous linings; fine krotovina filled with dark material as above; structure obscured by level of calcareous cement; gradual boundary

82-154 C3k Grayish-brown (2.5Y 5/2) silty clay, trace fine sand; very firm; blocky; heavily calcified; calcification decreases slightly with depth; few charcoal pieces; common open rootlet holes with calcareous linings; few orange sand filled insect burrows; few brownish-white, soft calcareous concretions; clear boundary

154-280 C4ca Light olive-brown (2.5Y 5/3) very sandy clay and light yellowish-brown (2.5Y 6/4) silty, fine-grained sand, clayey in part; sand/silt content of zone varies with depth; clay-rich portions have weak, blocky structure and are firm with few clear calcite crystals, diffuse pale orange mottles, especially after rootlet traces, mottling increases to $50 \%$ of clay-rich zones towards base of trench, common open rootlet holes with calcareous coatings; sand rich portions are massive, friable to firm with few dark Fe mottles, few rounded pieces of ironstone, common open rootlet holes and common blackish-purple flecks of decaying organics

\section{BACKHOE TRENCH 2}

Elevation: $234.4 \mathrm{~m}$; light scatter of cultural material on surface to the east of the trench

0-4 C Light brownish-gray to light gray (10YR 6/2 to $7 / 2$ dry) silty fine-grained sand; loose; abundant rootlets; abrupt boundary 
4-54 2A1 Very dark grayish-brown (10YR $3 / 2$ to $2.5 \mathrm{Y} 3 / 2)$ slightly silty clay; firm; weak blocky to massive; abundant rootlets that decrease in number with depth; few fine krotovina and bug burrows; few open rootlet holes; clear boundary

54-84 2A2 Dark gray (10YR 4/1) clayey silt; firm; weak blocky; few open rootlet holes most with calcareous coatings; common insect burrows filled with sandy material; gradual boundary

84-150 2ACca to Grayish brown (10YR 5/2) grading to light yellowish-brown 2C1ca $2 \mathrm{C} 1 \mathrm{ca} \quad(2.5 \mathrm{Y} 6 / 3)$ sandy clay and clayey sand; very firm; massive; few shell fragments; common insect burrows many sand-filled; grain size varies with depth; common soft, white calcareous concretions which increase in number with depth particularly in clay rich portions; common open rootlet holes with calcareous linings; common open rootlet holes and blackish-purple decaying organic material in clay-rich portions; few orange Fe stains; gradual boundary

150-220 2C2kg Light brownish gray (2.5Y 6/2) fine, sandy silt to fine, sandy, silty clay; massive to fine blocky in clay rich portions; very firm to dense; common dark orange mottles; common purple-black decaying organic material; common open rootlet holes with calcareous linings; zone heavily cemented with calcareous material

\section{BACKHOE TRENCH 3}

Elevation: $234.4 \mathrm{~m}$

0-2 C Loose, light gray silty sand as at top of BHT 2; abrupt boundary

2-165 2A Very dark gray to very dark grayish-brown (10YR $3 / 1$ to $3 / 2$ ) slightly silty clay; massive to blocky; firm to plastic; wetting front from recent rains at a depth of $85 \mathrm{~cm}$ - unit very dark grayish-brown (2.5Y 3/2) below this point; common rootlets which decrease in number with depth; common insect burrows and woody roots; few to common open rootlet holes; rootlet holes often with calcareous linings; below wetting front, zone has blocky structure with sand coats on ped faces; common black decaying rootlets in lower portion; zone grades texturally to zone below; gradual to diffuse boundary

165-210 2C Grayish-brown (10YR 5/2) fine, sandy silt to silty, fine-grained sand; massive; firm to friable; common black decaying organic material; common open rootlet holes with calcareous linings; clear to abrupt boundary 
210-255 3Abca Very dark grayish-brown to dark grayish-brown (2.5Y $3 / 2$ to 4/2) clay; coarse to medium blocky; firm; heavy, fine- to medium-grained sand coats on ped faces; zone's color lightens slightly with depth being olivebrown at base (2.5Y 4/3); common flecks of black, decaying organic material and open rootlet holes; calcareous deposits in rootlet holes and along old rootlet traces; common fine krotovina filled with white to lightyellow sand; few small pebbles and shell fragments; few soft, white calcareous concretions $5 \mathrm{~mm}$ in size; gradual to diffuse boundary

255-295 3C1c Olive-brown (2.5Y 4/3) clay; fine blocky; firm; heavy sand coats on ped faces; common open rootlet holes with calcareous linings; abundant purple-black decaying organic material and stain; few fine FeMn concretions; several 3-5 cm thick lenses of light yellowish-brown (2.5Y $6 / 4$ ), fine-grained sand; firm to friable with common quartz, chert, and ironstone gravels up to $4 \mathrm{~cm}$ in size; sand bodies have abrupt irregular contacts with the surrounding clay; gradual boundary

295-320 3C2 Light olive-brown (2.5Y 5/3) clay; fine blocky; firm; heavy sand coats on ped faces; common gravels; common open rootlet holes and decaying organic material as zone above; zone grades to a light yellowish-brown (2.5Y 6/4) fine-grained sand with common gravels at base of trench

\section{BACKHOE TRENCH 4}

Elevation: $235.3 \mathrm{~m}$

0-4 C Loose, light gray, silty sand as BHT 2 above; abrupt boundary

4-50 2A Very dark gray (10YR 3/1) clay, silty and sandy in part; weak blocky; firm; common rootlets and woody roots; common open rootlet holes with calcareous coatings; common open insect burrows; wetting front from recent rains at a depth of $32 \mathrm{~cm}$ - zone dark grayish-brown (10YR 4/2) below this depth; gradual to clear boundary

50-75 2Ck Grayish-brown (10YR 5/2) clayey silt, sandy in part; firm to friable; massive; common woody roots; highly calcified; common open rootlet holes with calcareous coats; clear boundary

75-220 3Ab Dark gray (10YR 4/1) clay; blocky; very firm; few woody roots; common open rootlet casts throughout, casts have calcareous coats in upper portion of zone; light-colored silt coats on ped faces in lower portion of zone; soil structure becomes stronger with depth and coats on ped faces become argillaceous; zone grades to a silty clay with depth; gradual boundary

220-280 3AC Dark grayish-brown (2.5Y 4/2) silty clay; very firm; strong blocky; common open rootlet casts with calcareous linings; few pieces of charcoal; clear boundary 
280-310 3C1ca Grayish-brown to light grayish-brown (2.5Y 5/2 to 6/2) silty clay; strong blocky; very firm; common $10 \mathrm{~mm}$ hard calcareous concretions; common diffuse orange mottles; common purple-black FeMn stain; common open rootlet casts with calcareous linings; clear boundary

310-350 3C20x Light olive-brown (2.5Y 5/3) clay; very firm; strong blocky; zone has abundant orange (2.5YR $6 / 4$ to $6 / 6$ ) mottles, mottling on $40-50 \%$ of zone

\section{BACKHOE TRENCH 5}

Elevation: $235.6 \mathrm{~m}$; light scatter of cultural material on surface

0-15 A Dark grayish-brown (10YR 4/2), loamy silt; friable; massive; abundant rootlets; common woody roots; diffuse to gradual boundary

15-95 AC Brown (10YR 5/3) silty clay; firm; blocky; common woody roots; common decaying, humic organic matter; common rootlet casts, some with calcareous coats near base of zone; clear to gradual boundary

95-125 C1ca Light yellowish-brown (2.5Y 6/3), clayey silt; friable to firm; weak blocky; common large, clear calcareous crystals; common decaying humic matter; common open rootlet casts and insect burrows; gradual boundary

125-245 C2ca Light yellowish-brown (2.5Y 6/3 to 6/4), silty, fine-grained sand; friable; massive; zone slowly coarsens to a depth of $180 \mathrm{~cm}$ and then gradually fines to a very fine sandy silt at its base; common clear calcareous crystals as above; few shell fragments; clear boundary

245-307 C3gca Light brownish-gray (2.5Y 6/2), very fine, sandy silt; friable; massive; abundant hard calcareous concretions $10 \mathrm{~mm}$ in size; common flecks of black organic material; abundant orange (2.5Y 5/6) mottles; common open rootlet casts some with calcareous coats

\section{BACKHOE TRENCH 6}

Elevation: $232.6 \mathrm{~m}$

0-105 A1 Very dark gray (10YR 3/1) clay; massive; plastic; sandy in part; abundant rootlets and woody roots which decrease in number with depth; gradual boundary

105-140 A2 Dark gray (10YR 4/1), finely interbedded clay and silty fine-grained sand; massive to weak blocky; firm; common rootlets and woody roots that decrease in number with depth; clear to abrupt boundary

140-200 2Abca Very dark gray (10YR 3/1) clay; very firm; massive-to-weak blocky; sand coats on ped faces; abundant gravels from $2 \mathrm{~mm}$ to $4 \mathrm{~cm}$ in size; common calcareous concretions; few to common orange mottles that increase in number with depth; clear boundary 
200-250 2C1ccaox Very dark grayish-brown (2.5Y 3/2) clay; weak coarse blocky; firm to very firm; heavy, medium-grained orange sand coats on ped faces; common gravels from $2 \mathrm{~mm}$ to $4 \mathrm{~cm}$ in size; few fine, hard $\mathrm{FeMn}$ concretions; common open rootlet casts with calcareous coats; common hard calcareous concretions; abundant greenish-orange mottles (30-50\% of zone); clear to abrupt boundary

250-275 2C2ca Very dark grayish-brown (2.5Y 3/2) clay; friable to firm; fine strong blocky; common rootlet casts, some filled with white calcareous crystals and others open with calcareous coats; abundant white calcareous crystals giving zone a black-and-white appearance; common large greenish-orange mottles as above; water table at base of trench

\section{BACKHOE TRENCH 7}

Elevation $235.3 \mathrm{~m}$; light scatter of cultural material at surface

0-4 C Gray sand; loose, friable; abrupt boundary

4-89 2A Very dark grayish-brown (2.5Y 3/2), silty clay; firm; blocky; sand coats on ped faces; common rootlets and woody roots in upper portion; common open rootlet casts; common tree root holes filled with decaying humic matter; clear to gradual boundary

89-144 2Bca Dark grayish-brown (10YR 4/2) clay; very firm to dense; strong medium blocky; medium-grained sand coats on ped faces; common open rootlet casts; common white, decaying, calcareous concretions $1 \mathrm{~cm}$ in size; clear to gradual boundary

144-189 2C1ca Grayish-brown (2.5Y 5/2) clay; very firm; blocky; sand coats on ped faces; few white, decaying, calcareous concretions $1 \mathrm{~cm}$ in size; clear boundary

189-240 2C2ca Light olive-brown (2.5Y 5/3) clay; strong blocky; very firm; common open rootlet casts and insect burrows; common decaying, black rootlets; few white, decaying, calcareous concretions; few fine FeMn concretions; common clear calcareous crystals particularly on ped faces; few small pebbles; orangish sand and silt coats on ped faces; common open rootlet casts with calcareous linings; clear boundary

240-320 2C3geca Light brownish-gray to light yellowish-brown (10YR 6/2 to $2.5 \mathrm{Y} 6 / 2$ to $6 / 3$ ) clay; fine blocky; very firm; sand coats on ped faces; many ped faces covered with calcareous crystals; common fine FeMn concretions; abundant clear-to-milky-white calcareous crystals; common krotovina filled with pale gray sand; common open rootlet casts; below a depth of $285 \mathrm{~cm}$, zone has abundant vertical orange (10YR 4/6 to 5/6) mottles; up to $40 \%$ of zone mottled; below a depth of $3 \mathrm{~m}$, zone has common, white, soft, $1-2 \mathrm{~cm}$ calcareous concretions; below a depth of $285 \mathrm{~cm}$, zone has several $5 \mathrm{~cm}$ thick beds of grayish-brown to light grayish-brown $(2.5 \mathrm{Y}$ $5 / 2$ to $6 / 2$ ) silt 


\section{BACKHOE TRENCH 8}

Elevation: $234.1 \mathrm{~m}$

\begin{tabular}{|c|c|c|}
\hline $0-4$ & $\mathrm{C}$ & $\begin{array}{l}\text { Loose, light gray sand anchored by abundant grass rootlets; abrupt } \\
\text { boundary }\end{array}$ \\
\hline $4-39$ & $2 \mathrm{~A} 1$ & $\begin{array}{l}\text { Very dark gray (10YR } 3 / 1 \text { ) clay; massive; firm to plastic; commor } \\
\text { rootlets; common decaying humic matter; abrupt, smooth boundary }\end{array}$ \\
\hline $39-69$ & $2 \mathrm{~A} 2$ & $\begin{array}{l}\text { Finely interbedded, very dark gray (10YR } 3 / 1) \text { clay as above and white, } \\
\text { pale gray sand which is very friable to loose and massive; bedding } \\
\text { horizontal to subhorizontal dipping very gently to the northwest in trench } \\
\text { wall; beds } 2 \text { to } 3 \mathrm{~cm} \text { thick; common krotovina filled with material from } \\
\text { overlying zone; abrupt, smooth boundary }\end{array}$ \\
\hline $69-250$ & $\begin{array}{l}2 \mathrm{~A} 3 \text { to } \\
2 \mathrm{C} 1 \mathrm{gca}\end{array}$ & $\begin{array}{l}\text { Very dark gray }(10 \mathrm{YR} 3 / 1) \text { grades quickly }(15 \mathrm{~cm}) \text { to light brownish-gray } \\
(10 \mathrm{YR} 6 / 2 \text { to } 2.5 \mathrm{Y} 6 / 2) \text { clay; firm to plastic; massive; few woody roots; } \\
\text { abundant greenish-blue and black ( } 5 \mathrm{Y} 5 / 1 \text { to } 5 / 2 \text { but greener) decaying } \\
\text { rootlets; few large, white, decaying calcareous concretions; common } \\
\text { orange mottles and clear calcareous crystals; gradual boundary }\end{array}$ \\
\hline $250-280$ & $2 \mathrm{C} 2 \mathrm{gcca}$ & $\begin{array}{l}\text { Gray ( } 2.5 \mathrm{Y} \text { N/6) clay; blocky; firm to very firm; common orange } \\
\text { mottles; few FeMn concretions; few hard calcareous concretions; gradual } \\
\text { boundary }\end{array}$ \\
\hline $280-300$ & 2C3gcca & $\begin{array}{l}\text { Gray }(5 \mathrm{Y} 5 / 1 \text { to } 6 / 1) \text { sandy clay; firm; weak, blocky to massive; } \\
\text { common, } 5 \mathrm{~mm}-1 \mathrm{~cm} \text { hard, calcareous concretions and orange mottles; } \\
\text { few FeMn concretions }\end{array}$ \\
\hline
\end{tabular}

\section{BACKHOE TRENCH 9}

Elevation: $237.4 \mathrm{~m}$

0-3 C Pale brown sand; loose; abrupt boundary

3-63 2A Very dark gray (10YR 3/1) lightens to very dark grayish brown (10YR 3/2) silty clay; massive; friable to firm; common rootlets; common open rootlet casts and insect burrows; gradual boundary

63-88 2AC Dark grayish-brown to brown (10YR 4/2 to 5/3) clay; blocky; firm; silt and sand coats on ped faces; zone lightens slightly with depth; bioturbated with common open rootlet casts and insect burrows; common decaying humic matter; few rootlets; gradual boundary 
88-280 2C1cca Light yellowish-brown to very pale brown (10YR 6/4 to 7/4) clayey silt; friable to firm; weak blocky to massive; trace of calcareous cement; common 1-3 cm calcareous concretions; common krotovina; abundant open rootlet casts and insect burrows, some rootlet casts have black decay stain; zone grades to a silty, fine-grained sand at a depth of $218 \mathrm{~cm}$; below this depth, zone consists of alternating zone of light brownish-gray to light yellowish-brown (2.5Y 6/2 to 6/3) sandy silt, firm with blocky structure and pale yellow (2.5Y 7/4), silty, fine-grained sand, friable and massive; common fine FeMn concretions throughout this portion of zone; silt and sand intervals grade back and forth with siltier portions being marked by prominent horizontal zones of white calcareous concretions; clear to gradual boundary

280-315 2C2c Light olive-brown (2.5Y 5/3) silty fine-grained sand; firm; massive; common orange (10YR 5/6) mottles; abundant fine FeMn concretions; common open rootlet casts; several horizontal bands of sand containing very abundant fine pieces of black decaying organic material; at a depth of $295 \mathrm{~cm}$ there is a $5-10 \mathrm{~cm}$ thick bed of rounded limestone, chert, and quartzite gravels

\section{BACKHOE TRENCH 10}

Elevation: $238.0 \mathrm{~m}$; light scatter of cultural material on surface

0-5 C Light grayish-brown sandy silt; loose; abrupt boundary

5-47 2A Very dark grayish-brown (10YR 3/2) clay to silty clay; weak blocky; firm; common rootlets and woody roots; common open rootlet casts and insect burrows; few small pebbles; gradual boundary

47-67 2AC Brown (10YR 5/3) silty clay; firm; blocky; sand coats on ped faces; common rootlets and woody roots; common fine krotovina; gradual boundary

67-83 2C1 Brown (10YR 5/3) clay; firm; blocky; common rootlets and dark filled fine krotovina; common small pebbles and open rootlet casts; clear boundary

83-133 2C2k Brown (10YR 5/3) silty clay, fine, sandy in part - level of calcification obscures texture; very firm to dense; blocky; abundant white decaying 1-3 cm calcareous concretions; few small ironstone pebbles; common fine dark-filled krotovina; common open rootlet casts; gradual to clear boundary

133-180 2C3 Light yellowish-brown (2.5Y 6/4) silty fine-grained sand; firm; massive; 190 common small ironstone gravels; common fine krotovina filled with material from overlying zone; common open rootlet casts; abrupt, irregular boundary 
$1803 \mathrm{Ck}$ Gravel up to $10 \mathrm{~cm}$ in size in silty, sand matrix as zone above; abundant 190-197

210

$197 \quad 4 C 1 \mathrm{ca}$

$210-250$ purplish-black decaying organic matter; zone dips north in trench wall; abundant calcareous cement as coatings on gravels and as cement in surrounding sand; zone clayey in part; abrupt, smooth, wavy boundary

250-280 4C2ca Very pale brown (10YR 7/4), silty, fine-to-very-fine-grained sand; firm to

Light yellowish-brown (2.5Y 6/4 to 10YR 6/4), silty, fine-grained sand; friable; massive; common flecks purplish-black decaying matter; common open rootlet casts; silt content of zone varies with depth; siltier zones marked by horizontal layers of white calcareous concretions, $1-3 \mathrm{~cm}$ in size; clear boundary friable; massive; common white calcareous concretions as overlying zone; common open rootlet casts with calcareous coatings; common open insect burrows; some calcareous cement in upper portion of zone that decreases with depth

\section{BACKHOE TRENCH 11}

Elevation: $235.0 \mathrm{~m}$

$\begin{array}{cc}0-4 & \mathrm{C} \\ 4-64 & 2 \mathrm{~A}\end{array}$

Gray sandy silt; loose; abrupt boundary

4-64

Very dark grayish-brown (10YR 3/2) clay; weak blocky; firm; common woody roots and rootlets; common open rootlet casts; trace calcite in lower portion; clear to gradual boundary

64-95 2AC Dark grayish-brown (10YR 4/2) clay, sandy in part; weak fine blocky; firm; common roots and rootlets; pockets of decaying humic matter; common open rootlet casts with calcareous coats; gradual boundary

95-125 2C1 Dark grayish-brown (2.5Y 4/2) fine sandy silt; massive to weak blocky; firm to friable; common rootlets and woody roots; common dark-filled krotovina; pockets of decaying humic matter; common rounded quartz, chert, and ironstone gravels up to $2 \mathrm{~cm}$ in size; 3 pieces of burned rock; 2 whole snail shells (Rabdotus); diffuse boundary

125-173 2C2 Dark grayish-brown (2.5Y 4/2), silty, fine-grained sand; massive; friable; few dark-filled krotovina; few woody roots; common open rootlet casts; clear boundary

173-195 2C3k Light olive-brown (2.5Y 5/3), silty, fine-grained sand; dense to very 210 firm; structure obscured by cementing; zone calcified with abundant calcareous cement; boundary smooth, wavy, and dips to west in trench wall

195 3Abc Dark grayish-brown (10YR 4/2 to 2.5Y 4/2) clay; strong to blocky; firm; $210-270$ common open rootlet casts many with calcareous $3 \mathrm{C} 1 \mathrm{cca}$ coats; few small pebbles; few fine FeMn concretions; few hard, calcareous concretions 5 $\mathrm{mm}$ in size in lower portion; clear boundary 
270-290 3C2ca Light olive-brown (2.5Y 5/3), fine-grained sand; massive; friable; clean; abundant rounded quartzite, ironstone, and chert gravels up to $5 \mathrm{~cm}$ in size; several cycles of finely horizontally-bedded sands with thinnest bed cycles at top of zone; cycles marked by horizontal layers of white, $1-3 \mathrm{~cm}$ calcareous concretions

\section{BACKHOE TRENCH 12}

Elevation: $235.0 \mathrm{~m}$; at north end of site $41 \mathrm{MV} 187$; fairly dense scatter of cultural material at surface just to south

0-5 C Light gray sand and silt; loose; abundant grass rootlets; abrupt boundary

5-65 2AC Dark grayish-brown (10YR 4/2) clay; blocky; firm; common rootlets and woody roots; two flakes: one at a depth of $25 \mathrm{~cm}$ and one at $50 \mathrm{~cm}$; clear boundary marked by white, calcareous concretions

65-81 2C1ca Brown (10YR 5/3) clay; blocky; firm; heavy sand coats on ped faces; common dark-filled krotovina; common open rootlet casts with calcareous coats; common $1 \mathrm{~cm}$ white soft calcareous concretions; clear to gradual boundary

81-98 2C2 Light yellowish-brown (2.5Y 6/3) silt, fine, sandy in part; firm to friable; blocky; sand coats on ped faces; few dark-filled krotovina; common open rootlet casts and insect burrows; rootlet casts have calcareous coats; boundary is clear textural change

98-155 2C3cca Light yellowish-brown (2.5Y 6/3) sandy silt; massive; friable; zone grades downward to a silty sand; color becomes slightly darker being light olive-brown (2.5Y 5/3) at base; common fine FeMn concretions and fine, white, soft calcareous concretions; common open rootlet casts; clear boundary

155-200 2C4ca Light olive-brown (2.5Y 5/3) silt with many sand interbeds; firm; massive; sand interbeds are 1-5 mm thick and horizontal; interbeds occur in bands $2-4 \mathrm{~cm}$ in thickness; common krotovina filled with dark humic material; common open rootlet casts with calcareous coats; common-toabundant, white, soft calcareous concretions; clear boundary

200-260 2C5cca Dark grayish-brown (2.5Y 4/2), fine, sandy clay; blocky; firm; many dark-filled krotovina in upper portion; common FeMn concretions; few fine orange $\mathrm{Fe}$ mottles at base; common rootlet casts with heavy calcareous coats; common $2-3 \mathrm{~cm}$ white calcareous concretions; gradual boundary

260-291 2C6cca Pale brown (10YR 6/3) silty fine-grained sand, clayey in part; firm to friable; massive; common fine FeMn and white calcareous concretions; abundant semi-vertical orange mottles, up to $70 \%$ of zone mottled; common open rootlet casts some with calcareous coats; $6 \mathrm{~cm}$ thick silty, clayey sand layer at base; clear to abrupt boundary 
291-340 3Cc Pale brown to very pale brown (10YR 6/3 to 7/4), slightly silty, fine-tomedium-grained sand; friable; massive; few fine hard FeMn concretions; two 3-cm thick bands of sand enriched with black flecks of decaying organics that are truncated by overlying zone; bands are subhorizontal and dip north in trench wall; common, diffuse orange mottles; few darkfilled krotovina

\section{BACKHOE TRENCH 13}

Elevation: $244.4 \mathrm{~m}$; southern portion of site 41MV160 near Shovel Test 4, south of main surface scatter of cultural material
$0-2$
$\mathrm{C}$
Gray sand; loose; abrupt boundary
2-38
$2 \mathrm{~A} 1$
Very dark grayish-brown (10YR 3/2) clayey, fine, sandy silt; friable; common rootlets, woody roots, and open rootlet casts; burned rock at a depth of $36 \mathrm{~cm}$ in trench wall with few snail shells (Rabdotus); gradual boundary
38-60 2A2 Very dark grayish-brown (10YR 3/2), silty clay to clayey silt; blocky; firm to friable; sand coats on ped faces; common rootlets and woody roots; common humic-filled krotovina; clear downward leaching of dark fines into underlying zone; considerable amount of burned rock and worked chert between a depth of 48 and $55 \mathrm{~cm}$; gradual to clear boundary
60-90 2ACca or Dark grayish-brown to grayish-brown (10YR 4/2 to $5 / 2$ ), silty clay; firm; 2Bwca blocky; white sand coats on ped faces; common humic-filled krotovina; few soft, white, calcareous concretions; common snail shell fragments; common open rootlet casts some with calcareous coats; clear to abrupt boundary

90-170 2C Gravel, loose with little clay matrix, poorly sorted ranging in size from pea size to $15 \mathrm{~cm}$; common interbeds of coarse grained sand; zone fines slightly upwards; abrupt, wavy boundary

170-190 3Cgca Gray (5Y 6/1) sandy clay; massive; firm; common horizontal orange mottles; common $1 \mathrm{~cm}$ soft white calcareous concretions; zone gleyed

\section{BACKHOE TRENCH 14}

Elevation $239.9 \mathrm{~m}$ Light scatter of gravel at surface with few pieces of worked stone.

A Very dark gray (10YR 3/1) clay; firm; blocky; sand coats on ped faces; common rootlets; few to common gravels, $2-5 \mathrm{~cm}$ in size; common open rootlet casts in lower portion with calcareous coats; clear boundary 
56-76 C Brown to pale brown (10YR 5/3 to 6/3) sandy clay; strong fine blocky; firm to very firm; sand coats on ped faces; zone becomes increasingly sandy and silty towards base; common fine dark-filled krotovina; common open insect burrows and rootlet casts; some rootlet casts have calcareous coats; abrupt, irregular boundary

76-161 2C1k Pale brown (10YR 6/3) fine sandy silt; structure obscured by calcification at top becoming strong, fine blocky at base; few dark-filled krotovina; few gravels, $5 \mathrm{~cm}$ in size; zone heavily calcified being completely whitened at top, and up to $50 \%$ whitened below with areas of calcification being vertical; gradual to clear boundary

161-205 2C2ca Yellowish-brown (10YR 5/4) clayey silt grading to gravelly, fine-grained 245 sand; fine blocky; firm to very firm; common open rootlet casts some with calcareous coats; sandy portions of zone occur in low spots on underlying zone; boundary is abrupt, irregular, wavy, and marked by calcareous concretions and orange staining

205

R Finely-bedded siltstone and shale; siltstone dark grayish-brown (10YR 245-325 $4 / 3$ ) at upper contact with common yellow sulphur staining and crystals in weathered zone becoming white (5Y $8 / 2)$ with depth; shale is very dark gray (10YR 3/1) and waxy

\section{BACKHOE TRENCH 15}

Elevation: $238.4 \mathrm{~m}$

0-50 Aca

Very dark gray (10YR 3/1) silty clay; firm; massive; common rootlets; abundant gravels up to $10 \mathrm{~cm}$ in size; boundary marked by $10-15 \mathrm{~cm}$ thick transition zone which has grayed appearance, common dark-filled krotovina, and abundant white to light gray calcareous concretions

50-285 Ck to Light yellowish-brown (10YR 6/4), silty, fine-grained sand to fine sandy Ccca silt; very firm to dense; massive; common gravels up to $5-7 \mathrm{~cm}$ in size in upper portion that decrease in number with depth; zone lightens to very pale brown (10YR 7/4) with depth; zone gradually grows sandier with depth; few rootlets in upper portion; $40 \mathrm{~cm}$ above base of trench zone has few fine FeMn concretions and dark orange (10YR 6/4 to 6/6) mottles; upper portion of zone heavily calcified with vertical, calcareous mottles, soft, white calcareous concretions, and calcareous cement; calcification lessens with depth 


\section{BACKHOE TRENCH 16}

Elevation: $235.6 \mathrm{~m}$; light surface scatter of cultural material, with a few cultural objects to a depth of 20$30 \mathrm{~cm}$

0-50 A Very dark gray (10YR 3/1) silty clay; blocky; firm to friable; sand coats on ped faces; few woody roots and decaying humic matter filled krotovina; few gravels up to $10 \mathrm{~cm}$ in size in upper $20-30 \mathrm{~cm}$; abrupt irregular boundary

50-94 C1 Turbated zone consisting of chunks of overlying and underlying zone, $5-15 \mathrm{~cm}$ on a side; randomly mixed; probably the result of deep-root plowing when land was cleared for agricultural use; common rootlets; abrupt, irregular boundary

94-259 C2ca Pale brown (10YR 6/3) silty clay; blocky; very firm; sand and clear calcareous crystal coats on ped faces; few rootlet casts; few soft, white, calcareous concretions; few dark-filled krotovina; common flecks of black decaying organic matter in bottom half of zone; little calcareous material below a depth of $240 \mathrm{~cm}$; gradual boundary

259-320 C3gcea Gray to light grayish-brown (10YR 6/1 to 6/2) clay to sandy, clayey silt; firm to friable; blocky; abundant orange (10YR 6/6) mottles; few rootlet casts, some with calcareous coats; common black decaying rootlets and organic matter; few FeMn concretions; few soft, white, calcareous concretions $4 \mathrm{~cm}$ in size 
